\title{
Glacial Geology of the Shingobee River Headwaters Area, North-Central Minnesota
}

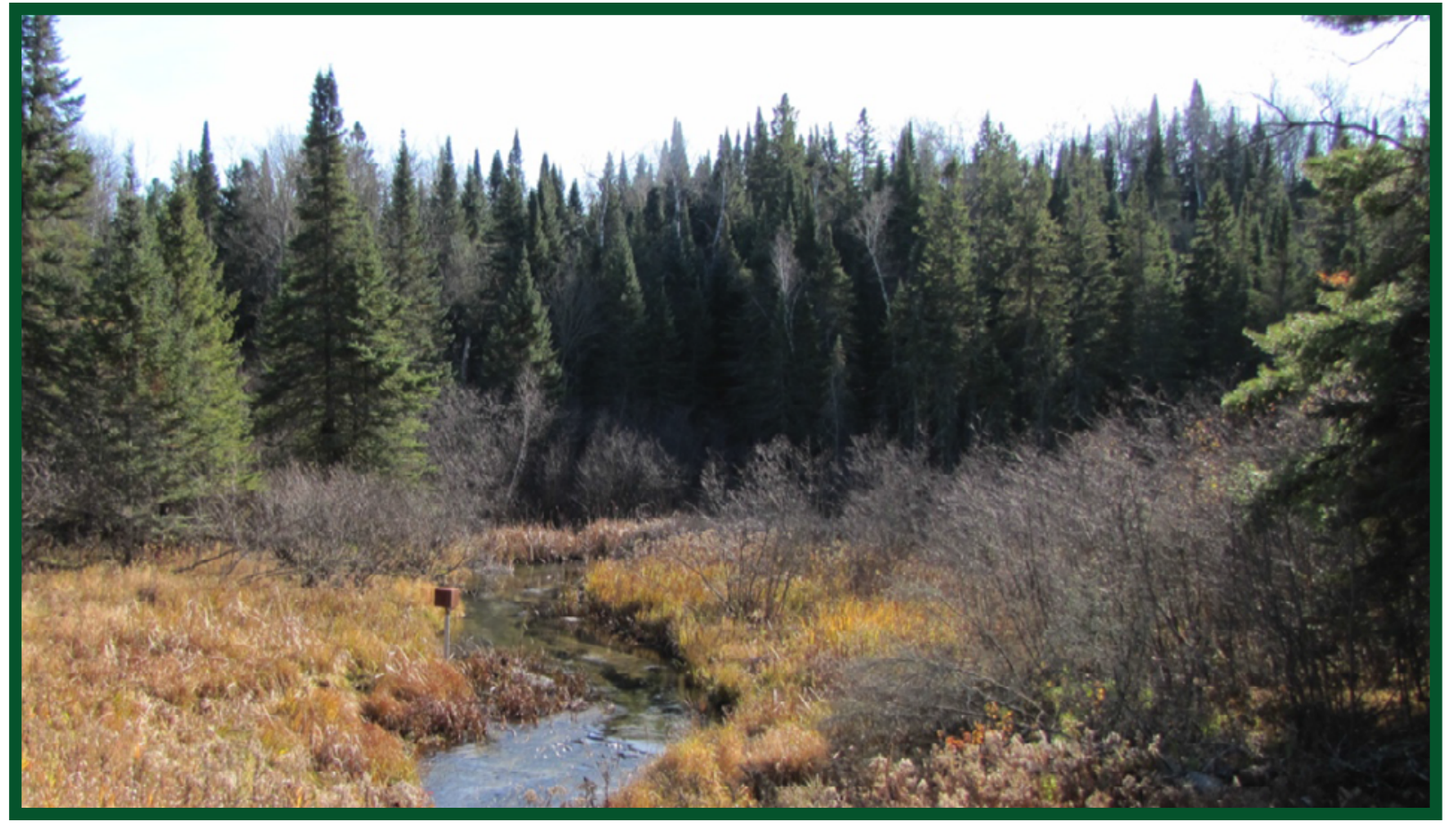

Scientific Investigations Report 2013-5165 
COVER. The Shingobee valley, looking upstream toward Shingobee Lake, about a mile and a quarter (2 kilometers) to the south. This part of the Shingobee River valley has a V-shaped cross section that was initiated during the draining of glacial Lake Willobee at the end of Wadena glaciation. The grassy fen on the left (eastern) bank is classified as "poor" because it lacks woody vegetation. The shrubby fen on the right (western) bank, in contrast, is called "rich" because plant nutrients are available in amounts sufficient to support woody vegetation and, commonly, the substrate is somewhat drier. The shrubby fen is developed on a local, relatively small apron of sediment consisting mostly of fine sand and silt derived from downslope movement along the steep western valley side. The asymmetrical occurrence of shrubs on one bank and nonwoody vegetation on the other suggests preferential groundwater input into the sediment wedge along the western valley side. 


\section{Glacial Geology of the Shingobee River Headwaters Area, North-Central Minnesota}

By Robert C. Melchior

Scientific Investigations Report 2013-5165 


\section{U.S. Department of the Interior \\ SALLY JEWELL, Secretary}

\section{U.S. Geological Survey \\ Suzette M. Kimball, Acting Director}

\section{U.S. Geological Survey, Reston, Virginia: 2014}

For more information on the USGS — the Federal source for science about the Earth, its natural and living resources, natural hazards, and the environment, visit http://www.usgs.gov or call 1-888-ASK-USGS.

For an overview of USGS information products, including maps, imagery, and publications, visit http://www.usgs.gov/pubprod

To order this and other USGS information products, visit http://store.usgs.gov

Any use of trade, firm, or product names is for descriptive purposes only and does not imply endorsement by the U.S. Government.

Although this information product, for the most part, is in the public domain, it also may contain copyrighted materials as noted in the text. Permission to reproduce copyrighted items must be secured from the copyright owner.

Suggested citation:

Melchior, R.C., 2014, Glacial geology of the Shingobee River headwaters area, north-central Minnesota:

U.S. Geological Survey Scientific Investigations Report 2013-5165, 47 p., http://dx.doi.org/10.3133/sir20135165.

ISSN 2328-0328 (online) 


\section{Contents}

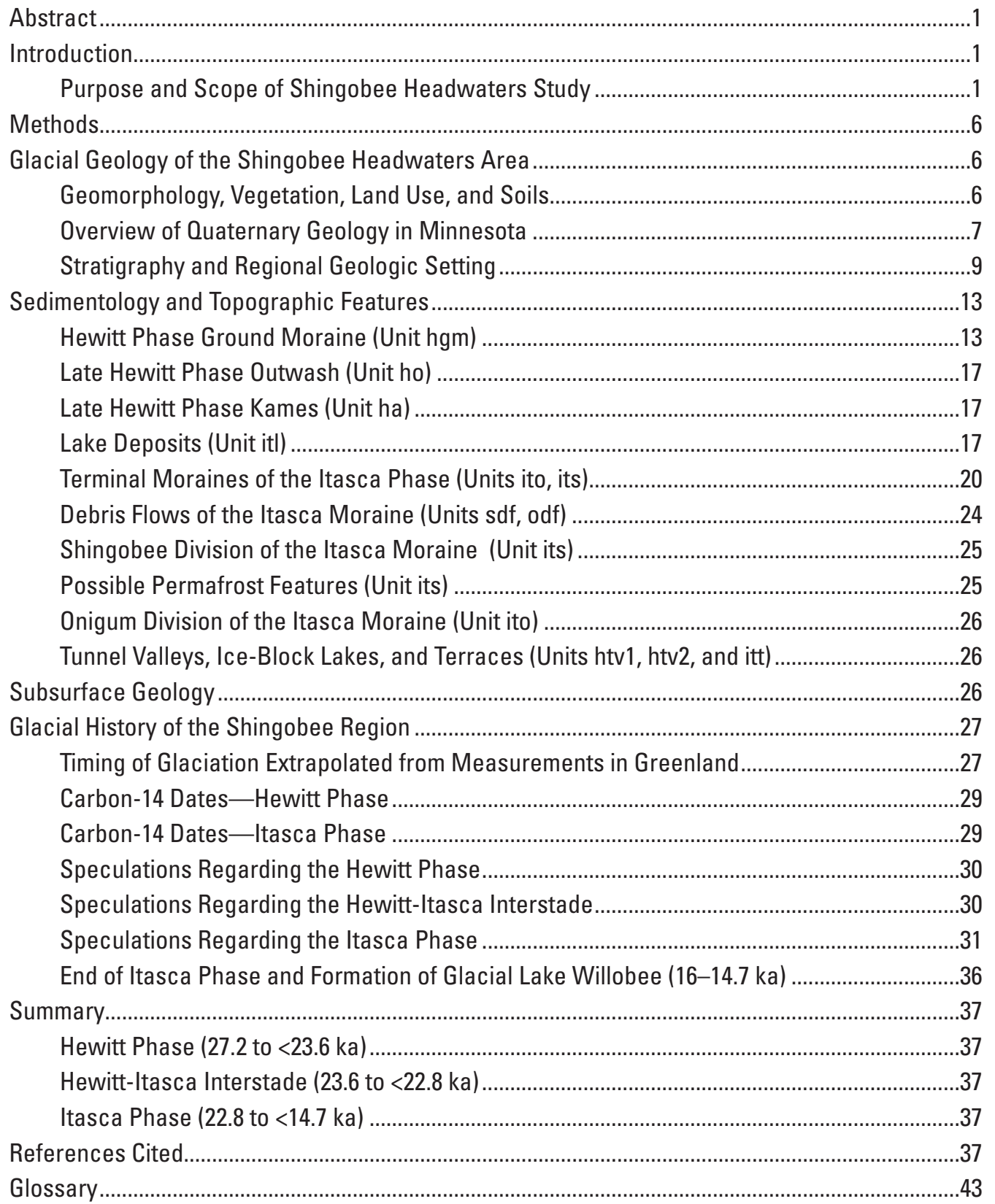

\section{Figures}

1. Map of surficial geology, Shingobee Headwaters study area..........................................2

2. Map of towns, major roads, lakes, and waterways in the Shingobee region ....................4

3. Map of middle to late Wisconsin glacial deposits and glaciations in Minnesota .............5

4. Map of Quaternary geology of north-central Minnesotaa .............................................8 
5. Shaded relief map showing prominent geomorphic features of the Shingobee region

6. Diagram of accumulation centers of Laurentide ice sheets that entered Minnesota....11

7. Map showing generalized distribution of till bodies in the Shingobee headwaters

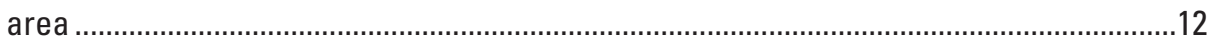

8. Shaded relief map of principal tunnel valleys in the Shingobee region..........................14

9. Shaded relief map showing distribution of Hewitt and Itasca phase glacial deposits in the Shingobee headwaters area .........................................................................15

10. Shaded relief map showing distribution of Hewitt phase outwash and ground moraine in the Shingobee headwaters area...

11. Shaded relief map showing distribution of Hewitt phase kames, tunnel valleys, and ground moraine in the Shingobee headwaters area.

12. Shaded relief map showing limits of glacial lakes Willobee and Crow Wing in the Shingobee headwaters area

13. Shaded relief map showing limits of Shingobee and Onigum divisions of Itasca moraine in the Shingobee headwaters area.

14. Block diagrams over shaded relief map of Shingobee headwaters area showing two styles of deposition within Itasca moraine.

15. Shaded relief map showing debris flows on the Itasca moraine in the Shingobee headwaters area.

16. Diagram of relative frequency of stone types in three tills of the Shingobee headwaters area.

17. Diagram of temperatures from Greenland Ice Sheet Project 2 ice cores .28

18. Diagram showing paleogeography of the Hewitt phase-Itasca phase interstade and final configuration of Itasca phase glacial tongues in the Shingobee headwaters area.

19. Map and cross sections of Shingobee River valley showing river terraces in the Shingobee headwaters area

20. Shaded relief map showing movement of Ah-Gwah-Ching with respect to Shingobee and Onigum divisions of the Itasca moraine during the latter part of the Itasca phase

21. Diagrammatic cross section and map showing formation of Ah-Gwah-Ching hill-hole pair in the Shingobee headwaters area.

\section{Table}

1. Dates of principal glacial events in the Shingobee region, north-central Minnesota....11 


\section{Abbreviations Used in This Report}

$\begin{array}{ll}< & \text { less than } \\ > & \text { greater than } \\ \approx & \text { nearly equal to } \\ \text { cal } & \text { calendar years } \\ \text { cal }^{*} & \text { calendar years calibrated from }{ }^{14} \mathrm{C} \text { dates } \\ { }^{14} \mathrm{C} & \text { carbon-14 } \\ \mathrm{cm} & \text { centimeter } \\ \mathrm{ft} & \text { foot, feet } \\ \mathrm{ft} / \mathrm{mi} & \text { feet per mile } \\ \mathrm{in} . & \text { inch } \\ \mathrm{ka} & \text { kiloannum (thousands of years ago) } \\ \mathrm{km} & \text { kilometer } \\ \mathrm{k} . \mathrm{y} . & \text { thousands of years } \\ \text { lat } & \text { latitude } \\ \text { long } & \text { longitude } \\ \mathrm{m} & \text { meter } \\ \mathrm{mm} & \text { millimeter } \\ \mathrm{m} / \mathrm{km} & \text { meters per kilometer } \\ \mathrm{mi} & \text { mile } \\ \mathrm{n} & \text { number of observations } \\ \mathrm{yr} & \text { year } \\ \mathrm{BP} & \text { before present }- \text { refers to }{ }^{14} \mathrm{C} \text { date } \\ \mathrm{DEM} & \text { Danital elevation model } \\ \mathrm{D}-\mathrm{O} & \text { Greenland Ice Sheet Project } 2 \\ \mathrm{GISP2} & \end{array}$





\title{
Glacial Geology of the Shingobee River Headwaters Area, North-Central Minnesota
}

\author{
By Robert C. Melchior ${ }^{1}$
}

\section{Abstract}

During middle and late Wisconsin time in the Shingobee River headwaters area, the Laurentide Wadena lobe, Hewitt and Itasca phases, produced terminal and ground moraine along with a variety of associated glacial features. The stratigraphic record is accessible and provides details of depositional mode as well as principal glacial events during the advance and retreat of middle and late Wisconsin ice tongues. Geomorphic features such as tunnel valleys, stream terraces, and postglacial stream cuts formed by erosional events persist to the present day. Middle Wisconsin Hewitt phase deposits are the oldest and include drumlins, ground moraine, boulder pavements, and outwash. Together, these deposits suggest a wet-based, periodically surging glacier in a subpolar thermal state. Regional permafrost and deposition from retreating ice are inferred between the end of the Hewitt phase and the advance of late Wisconsin Itasca phase ice. Itasca phase glaciation occurred as a contemporaneous pair of adjacent ice tongues whose contrasting moraine styles suggest independent flow modes. The western (Shingobee) portion of the Itasca moraine contains composite ridges, permafrost phenomena, hill-hole pairs, and debris flows. By contrast, eastern (Onigum) moraine deposits generally lack glaciotectonic features and consist almost exclusively of mud and debris flows.

Near the end of the Itasca phase, large-scale hill-hole pairs developed in the Shingobee division, and debris flows from the Onigum division blocked the preexisting Shingobee tunnel valley to form glacial lake Willobee. Postglacial streams formed deep valleys as glacial lake Willobee catastrophically drained. Dates based on temperature trends in Greenland ice cores are proposed for prominent glacial events in the Shingobee area. This report proposes that Hewitt phase glaciation occurred between 27.2 and 23.6 kiloannum and Itasca phase glaciation between 22.8 and 14.7 kiloannum. Des Moines lobe (Younger Dryas) glaciation, which had only secondary effects on the Shingobee headwaters area, occurred between 13.5 and 11.6 kiloannum.

\footnotetext{
${ }^{1}$ Professor Emeritus, Bemidji State University, Bemidji, Minn., U.S. Geological Survey volunteer
}

\section{Introduction}

In 1989, a multidisciplinary groundwater study was conceived by a group of U.S. Geological Survey scientists. The Shingobee River headwaters area was chosen for the proposed research because its features accommodated the group's principal objective - to compare a number of lakes within the same general hydrogeologic system that have different water residence times, atmospheric interactions, groundwater relationships, and biogeochemical characteristics. In late 2002, the name Shingobee Headwaters Aquatic Ecosystem Project was chosen to reflect the range of research activities taking place at Shingobee and the multidisciplinary nature of the project.

The Shingobee (from the Ojibwe word zhingobiig, balsam fir) headwaters area contains 11 lakes and 10 stream segments (Filby and others, 2002) and is located within the Upper Mississippi watershed. The area lies between latitudes $46^{\circ} 55^{\prime} 00^{\prime \prime} \mathrm{N}$. and $47^{\circ} 02^{\prime} 30^{\prime \prime} \mathrm{N}$. and between longitudes $94^{\circ} 37^{\prime} 30^{\prime \prime} \mathrm{W}$. and $94^{\circ} 45^{\prime} 00^{\prime \prime} \mathrm{W}$. in Cass and Hubbard Counties, north-central Minnesota (figs. 1, 2). Deposits of the Wadena and adjacent Rainy lobes (fig. 3), important components of the southern part of the Laurentide ice sheet, dominate the region.

\section{Purpose and Scope of Shingobee Headwaters Study}

Much of the previous research on glacial geology in north-central Minnesota has been regional in scope (Wright, 1972; Harris, 1975; Perkins, 1977; Goldstein, 1989). Norton (1983), however, presented detailed geologic descriptions of Shingobee landforms and deposits, and Mooers and Norton (1997) examined the geologic relations of the Shingobee headwaters area within the more local context of the Itasca-St. Croix interlobate moraine.

More-detailed studies are required to better define the timing of glacial events and to understand the complex relations between glacial deposits. This report describes the glacial geology of the Shingobee River headwaters area relative to sedimentology, topographic features, and glacial history. This information supports interpretations of groundwater systems and lake interactions. 


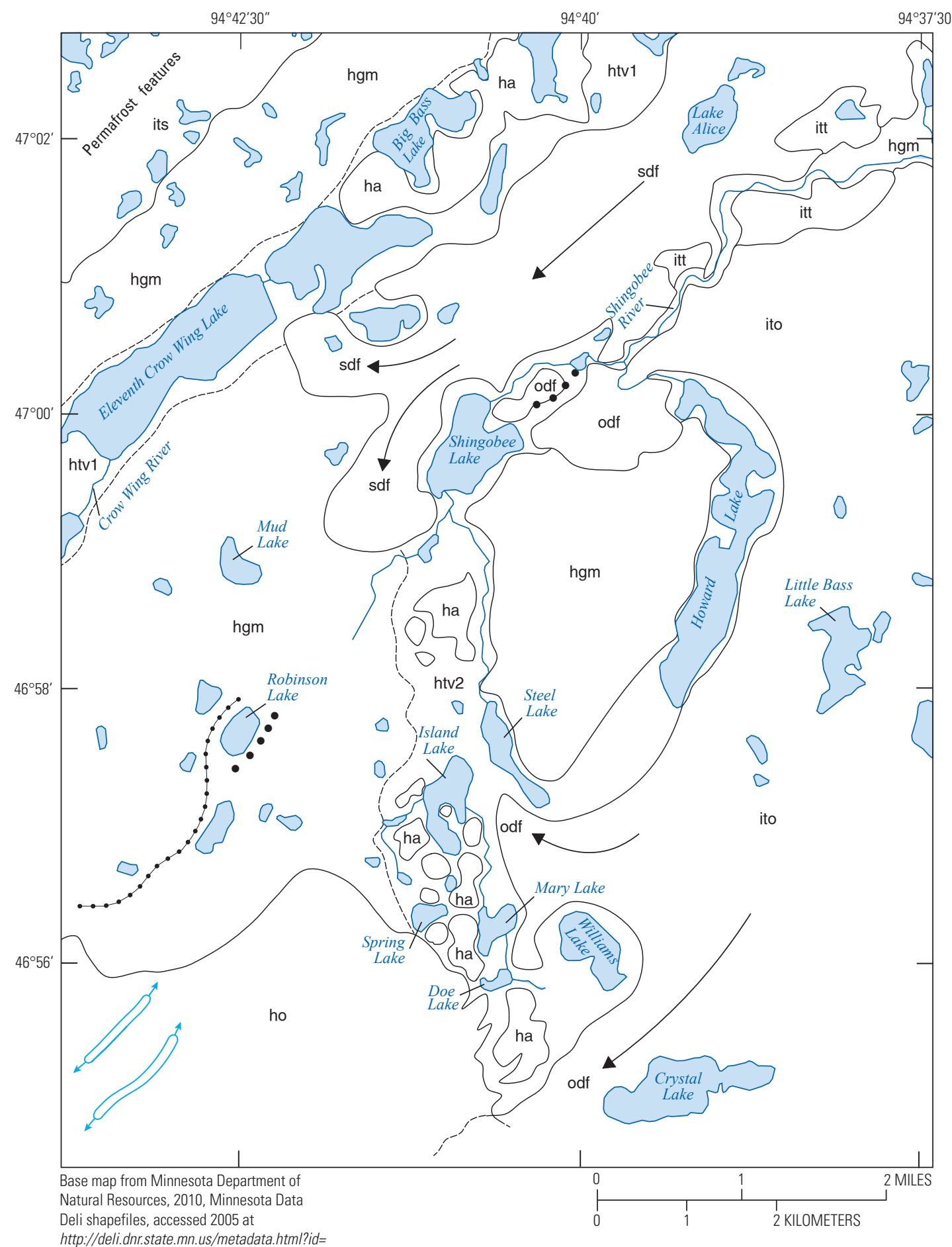

EXPLANATION

Boundary between map units

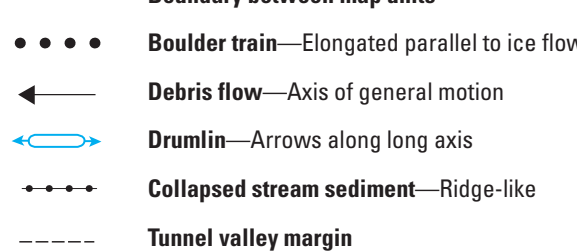

Figure 1. Surficial geology of the Shingobee Headwaters study area. $(<$, less than; $>$, greater than; ka, kiloannum.) 


\section{LIST OF MAP UNITS}

Itasca phase deposits

itt Stream terraces-Formed during the late stages and after the completion of the Itasca phase, younger than $14.7 \mathrm{ka}$

sdf Debris flow-Proglacial run-outs originating from the Shingobee division of the Itasca moraine, younger than $14.7 \mathrm{ka}$

odf Debris flow-Proglacial run-outs originating from the Onigum division of the Itasca moraine, younger than 14.7 ka

its Shingobee division of the Itasca moraine-Highly variable sediments, mostly derived from debris flows and mudflows produced on the margin of the Shingobee tongue of the Itasca phase glacier, 14.7-22.8 ka inclusive

ito Onigum division of the Itasca moraine-Highly variable sediments, mostly of debris and mudflow origin, produced on the margin of the Onigum tongue of the Itasca phase glacier, 14.7-22.8 ka inclusive

itl Lake deposits-Massive, laminated to varved, mostly silts to fine sands with sparse thin lenses of coarse sand or fine gravel; most associated with glacial Lake Willobee, about 14.7-16 ka

\section{Hewitt phase deposits}

ha Hewitt phase kames-Primarily poorly bedded gravels and sands that were deposited among collapsed ice blocks in subglacial tunnel valleys during the disintegration of the Hewitt-phase glacier. Approximate age, $23.5 \mathrm{ka}$

ho Hewitt phase outwash-Well-sorted sands and gravels deposited toward the end of the Hewitt-phase glaciation, $23.5 \mathrm{ka}$

htv1

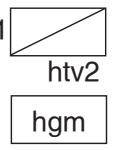

Tunnel valleys-Originated during Hewitt glaciation; may have remained active throughout the subsequent Itasca phase, 14.7-27.2 ka

Hewitt ground moraine-Sands and a few silts deposited at the base of the Hewitt phase glacier, characteristically sandy with intercalated gravel beds, older than $23.6 \mathrm{ka}$

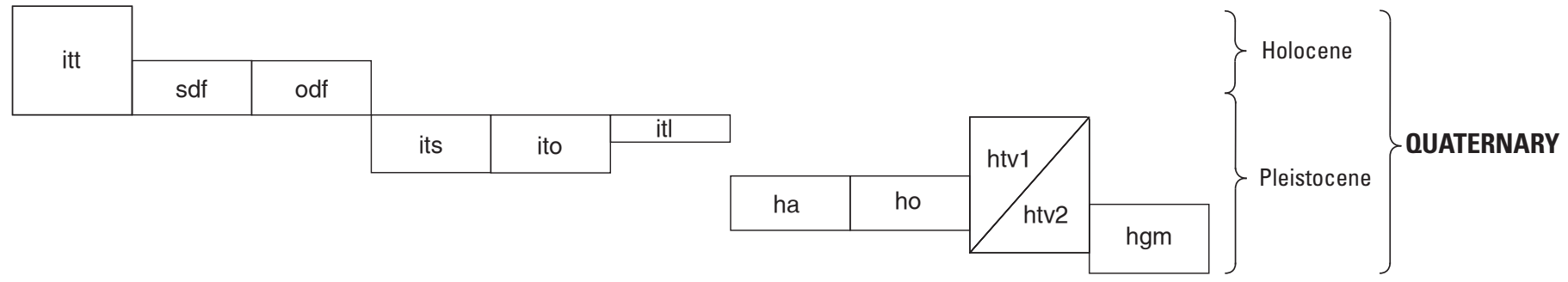

Figure 1-Continued. Surficial geology of the Shingobee Headwaters study area. $(<$, less than; $>$, greater than; ka, kiloannum.) 

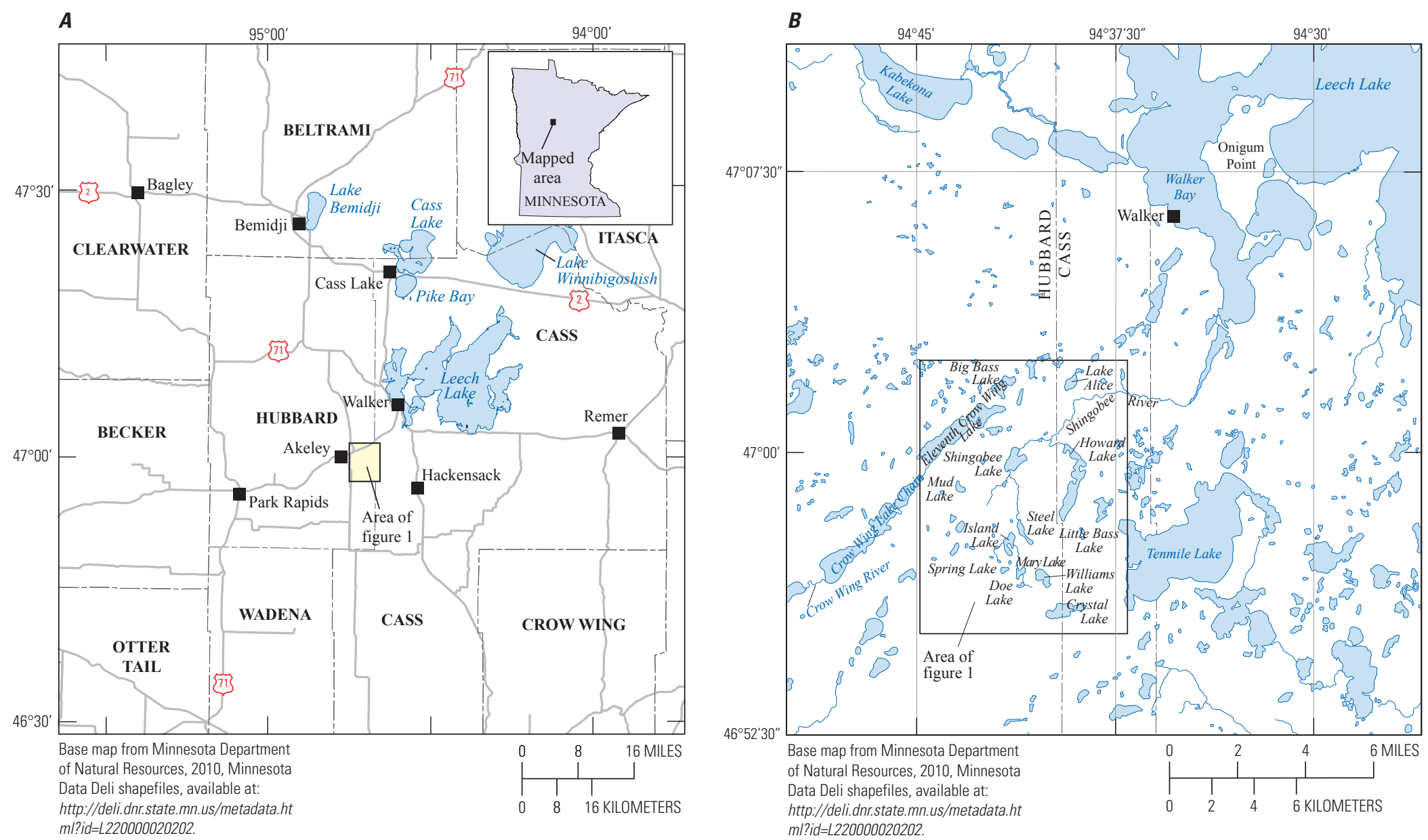

Figure 2. Features of the Shingobee region mentioned in the text. $A$, Cultural features. $B$, Lakes and waterways. Crow Wing River flows to the southwest through the Crow Wing lakes. 


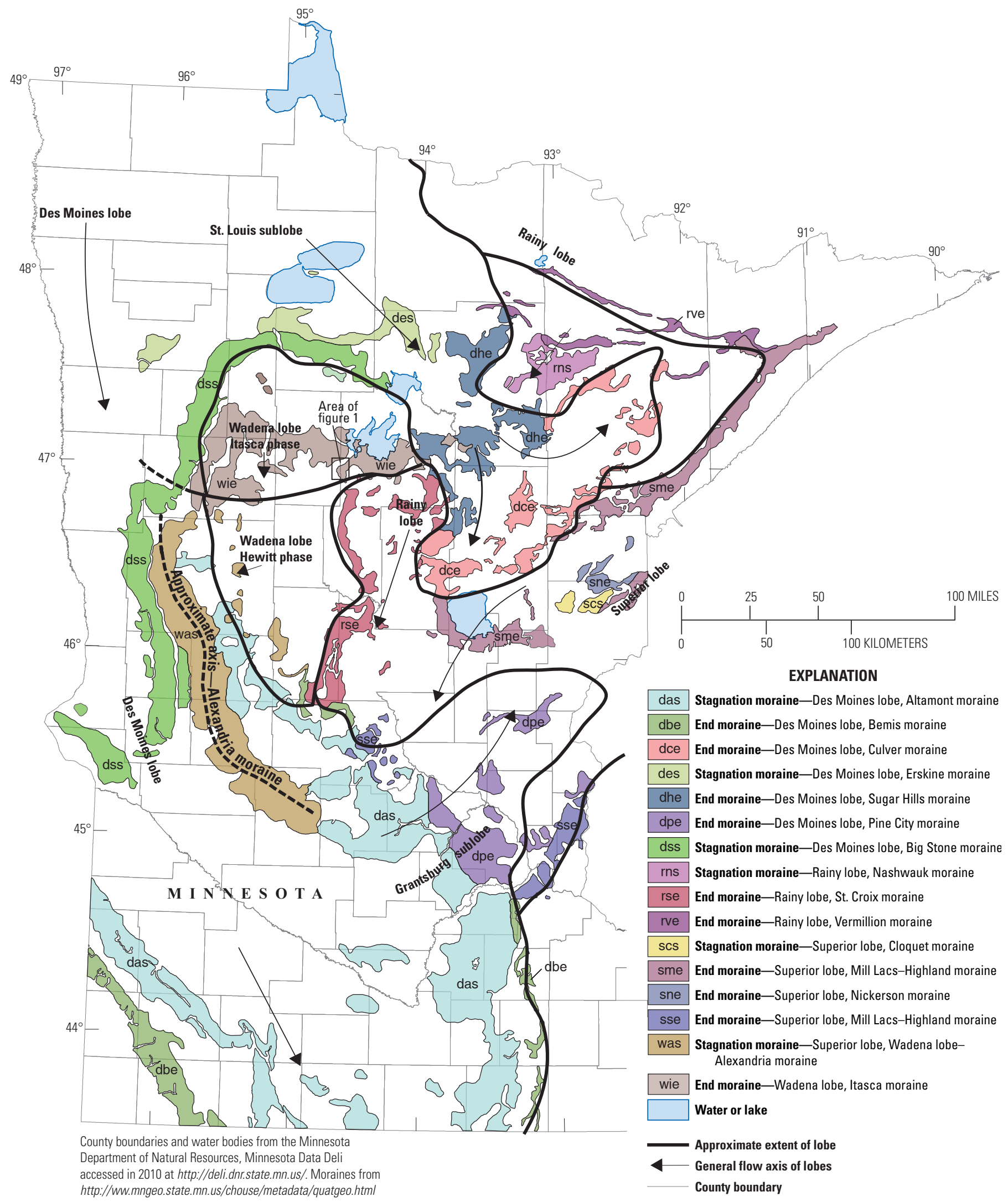

Figure 3. Middle to late Wisconsin glacial deposits and glaciations in Minnesota. Major moraine systems in Minnesota and distribution of surface deposits. Crosscutting relationships are shown; arrows denote general flow axes of the lobes. Source: Hobbs and Goebel (1982), Minnesota Department of Administration (1987), and Minnesota Department of Natural Resources (2010). 


\section{Methods}

Access to investigation sites in this report was by road or by logging and hiking trails. For the most part, access using roads and trails was adequate, although animal trails and cross-country travel were occasionally used.

Till lithologies derived from stone counts (also called pebble counts) have been a useful field tool for identifying glacial provenance for more than fifty years (for example, see Anderson, 1957, or Wright, 1962) and were used in the current instance to infer or confirm provenance of tills, not only in the Shingobee mapped area, but throughout the surrounding region as well. Counting procedures are typically applied to the pebble size class (4-16 millimeters $(\mathrm{mm})$ ) (Anderson, 1957 ) or to the coarse sand fraction (1-2 mm, Matsch, 1971). Both size classes have been shown to be reliable indicators of till provenance (Anderson, 1957). The pebble size class was used at Shingobee because it requires no equipment and pebbles can rapidly be assessed in the field. The procedure consisted of random selection of similar-size pebbles at an exposure, identification of pebble lithology (for example, basalt, granite, carbonate, and so forth), recording, and calculating the percentage of each rock type in the collected assemblage. Pebble counts were done at a variety of localities ranging from gravel mines and borrow pits (both active and inactive) throughout the Shingobee region and numerous sites (about 250) along road cuts on county and township roads, fresh slumps, and trails.

Sedimentological and stratigraphic data were derived from the literature (for example, Mooers and Norton, 1997), from geological sections extracted from well logs (available from Erickson, 1981; Karls, 1982; Minnesota County Well index, 2013; and, in graphical form, in Winter and Rosenberry, 1997) as well as lithologic information derived from till exposures available along road cuts within the map area and from nearby gravel pits. Some nearby pits were open and functional and yielded new sections as mining occurred. These included 4 in Hubbard County (Minnesota Department of Transportation (MnDOT) numbers 29081, 29067, 29042 and 29015), 4 in Cass County (MnDOT numbers 11107, 11101, 11127 and 11097), 4 in Clearwater County (MnDOT numbers 14012 , 15037, 15039, and 15001), and 3 in Beltrami County (MnDOT numbers 04043, 04089, and 04106) (Minnesota Department of Transportation, Aggregate Sources, County maps, 2003). Most smaller borrow pits throughout the region are not officially listed and were typically obscured by downslope movement of debris. Many of these sources were only sporadically active. Borrow pits were found along U.S. Department of Agriculture Forest Service roads and randomly distributed elsewhere throughout the area. Borrow pits were often employed for stone counts although a few, usable, short (less than $2 \mathrm{~m}$ ) sections containing sedimentological information were found in some. Regionally, available geologic sections in gravel pits were measured and analyzed to support or deny suppositions from Shingobee exposures. These more remote sections were correlated with the Shingobee area by using stone count data. Sections were obtained from 3 remote gravel pits north and west of Bemidji and 4 mining operations north, east, and south of Bagley (Minnesota Department of Transportation, 2003) (fig. 2). Data from these areas were also used to infer regional conditions that may have had an effect on the Shingobee area (for example, estimation of flow regime in drainageways, evidence of interglacial permafrost, dunes, and wind lags).

Till provenance coupled with geographic locality, stratigraphic position, cross-cutting relationships, and other stratigraphic and geomorphic observations established the identity of the mapped units represented in figure 1. Till lithology, as determined by stone count, was also used in the Shingobee region to support provenance inferred by other means (for example, superposition and crosscutting).

Geomorphology was examined by field observation accompanied by reference to topographic sheets (U.S. Geological Survey 1:24,000 series; Akeley, Walker, Benedict, Crystal Lake, Hackensack, Steamboat Bay quadrangles; Water Resources Investigations Report 96-4215, 1997) and digital elevation models (Minnesota Department of Natural Resources GIS Data Deli, 30 meter (m) resolution, 2010).

Greenland data used in figure 17 were derived from Alley, 2004. The trend line (fig. 17) was drawn using Microsoft Excel, which employs a least squares curve-fitting program. Available and appropriate ${ }^{14} \mathrm{C}$ dates from the literature were calibrated by using the Cologne Radiocarbon Calibration and Paleoclimate Research package (Danzeglocke, 2011).

Mapping was done by using overlays on digital elevation models, then ground checked and modified as required. Digital elevation models and other base maps were obtained at the Minnesota Data Deli site maintained by the Minnesota Department of Natural Resources (Minnesota Department of Natural Resources GIS Data Deli, 2010).

\section{Glacial Geology of the Shingobee Headwaters Area}

\section{Geomorphology, Vegetation, Land Use, and Soils}

The Itasca moraine is an end moraine of the late Wisconsin Wadena lobe, Itasca phase. It has the greatest local relief in north-central Minnesota (48 meters (m) or 157 feet (ft) within the boundaries of the moraine) and includes highlands

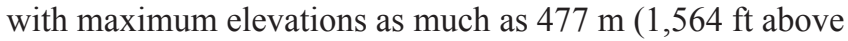
mean sea level (North American Vertical Datum of 1988; see Zilkoski and others, 1992) in the northern and eastern parts of the Shingobee headwaters area (fig. 1, units ito and its; figs. 3, 4, unit wie). An earlier, middle Wisconsin advance of the Wadena lobe (Hewitt phase, Wright, 1972) deposited ground moraine and formed drumlins. Ground moraine components and local outwash (fig. 1, units hgm and ho) in the Shingobee area generally have low to moderate local relief, 
about $31 \mathrm{~m}$ (102 ft). Relatively low local-relief outwash and fluvial units are found at elevations as high as $450 \mathrm{~m}$ $(1,476 \mathrm{ft})$ in the central, north-central, and northeast parts of the area (fig. 1, units htv1, htv2, itt). Overall, total relief within the Shingobee map area (see glossary and fig. 1) is

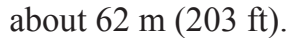

Because of their size and depth, tunnel valleys (fig. 1, units htv1, htv2; see glossary) are major topographic elements in the Shingobee regional landscape (fig. 5). Typically, they are incised about $30 \mathrm{~m}(100 \mathrm{ft})$. If valley-bottom-lake depths and small kames are excluded, tunnel valley floors generally have low relief, about $10 \mathrm{~m}(33 \mathrm{ft})$. Other geomorphic features in the region are stream terraces (fig. 1, unit itt), isolated kames (fig. 1, unit ha), and lobate debris flows (fig. 1, units odf, sdf), mostly derived from Itasca moraine (fig. 1).

In the east-central part of the Shingobee headwaters area, drainage is northeast through Shingobee River into Leech Lake (fig. 2). In the northwest part of this area, drainage flows into the Crow Wing Lake chain (fig. $2 B$ ), which flows to the southwest and then south as the Crow Wing River.

Anderson and others (2001) classified upland soils in the Shingobee region as Psamments, Boralfs, and Ochrepts. In glacial drainageways and other lowlands, poorly drained, peaty organic soils (Histosols; Anderson and others, 2001) underlie small bogs and fens. Siegel and Winter (1980) described vegetative cover as mixed coniferous-deciduous second-growth forest with openings dominated by grasses and herbaceous vegetation. A substantial amount of agricultural land, mostly used for pasture and hay, is also present in the area. Commercial tree farms, producing several species of pine, are common. The vegetation classification system currently used in Minnesota lists the area as being in the central dry-mesic pine-hardwood forest near the western side of the Laurentian mixed forest ecoregion (Wright and others, 2004).

\section{Overview of Quaternary Geology in Minnesota}

During the latter part of the Wisconsinan Stage (about 27.0 to 10.0 kiloannum (ka)), several ice lobes entered Minnesota from the Keewatin and Labradorean accumulation centers in central Canada (fig. 6). Ice lobes active in northern and central Minnesota include the Rainy and Superior lobes from the Labradorean center and the Des Moines and Wadena lobes from the Keewatin center (Wright, 1972; Mooers and Lehr, 1997). Superior lobe sediments were deposited about 120 kilometers $(\mathrm{km})(74 \mathrm{mi})$ east of, and about $90 \mathrm{~km}(56 \mathrm{mi})$ south of the Shingobee headwaters area (fig. 3). The Rainy lobe produced end moraine (St. Croix moraine) and associated outwash, ground moraine, and ablation deposits in the eastern and southern parts of northcentral Minnesota (fig. 4). Rainy lobe activity closer to Shingobee appears to have been more or less contemporaneous with activity of both Hewitt and Itasca phases of the Wadena lobe (see Wright, 1972). Deposits of the Des Moines and Wadena lobes dominate the western and northwestern parts of north-central Minnesota. In the immediate vicinity of the Shingobee headwaters, sediments of the Itasca and Hewitt phases (units its, ito, ho, and hgm) (fig. 1; see also fig. 7) make up almost all of the landscape.

A number of Minnesota terminal moraines were deposited by major Laurentide ice lobes during middle and late Wisconsin time (fig. 4). With the exception of some tills in the southwest corner of the state that may be as much as 700,000 years old, deposits of pre-Wisconsin glaciations are, for the most part, eroded or buried beneath younger units (Ojakangas and Matsch, 1982; Lusardi, 1996).

The youngest Wisconsin units in north-central Minnesota are associated with the Des Moines lobe and its subsidiary, the St. Louis sublobe, both of which overlie and crosscut previously deposited tills (Erskine and Big Stone moraines, figs. 3, 4). Des Moines lobe ice entered the state from the Keewatin center to the north-northwest and deposited tills with a high carbonate content (carbonate pebble count frequency of around 40 percent) and shale fragments derived from Paleozoic and Mesozoic outcrops in Manitoba, Canada (Thorleifson and others, 2007).

With the possible exception of minor amounts of outwash, Des Moines deposits are absent in the Shingobee region. The bulk of Des Moines till is associated with the Big Stone moraine, about 50 to $60 \mathrm{~km}(31-37$ miles (mi)) west and northwest of the Shingobee headwaters (figs. 3, 4), and the Erskine moraine, about $60 \mathrm{~km}(37 \mathrm{mi})$ north of the Shingobee headwaters. (figs. 3, 4, 5). The Des Moines lobe was active in Minnesota from about 13.5 to $11.6 \mathrm{ka}$ (table 1), when the ice began to retreat into Canada (Wright, 1993).

Wadena lobe glaciation is represented at Shingobee by the Itasca and Hewitt phases. Itasca phase (22.8-14.7 ka) (table 1) deposits (figs. 3, 4) dominate much of the northwestern and eastern parts of the Shingobee headwaters area (units its and ito, fig. 1).

Hewitt phase ice was present in the Shingobee area between 27.2 and $23.6 \mathrm{ka}$ (table 1). Traditionally, Hewitt phase deposits are identified with the Wadena lobe (Keewatin center, Wright, 1972). On the basis of lithology and directional indicators, however, Mooers and Lehr (1997) suggested that the Hewitt phase was a western ice stream of the Rainy lobe that originated from the Labradorean center (figs. 3, 6). They proposed that Hewitt deposits be assigned to the Rainy lobe. The term Wadena lobe, used to describe glaciers from the Keewatin accumulation area in north-central Manitoba, was also abandoned as problematic by other workers (Meyer and Knaeble, 1995), mainly because of temporal changes in lithological content present in many Wadena lobe tills in central Minnesota. While there is still considerable debate on this issue, an alternative term has not yet been widely accepted. Some studies (Carney and Mooers, 1998; Goldstein, 1998) continue to use the term "Wadena lobe" (Wright, 1972), which is also retained in this report. 


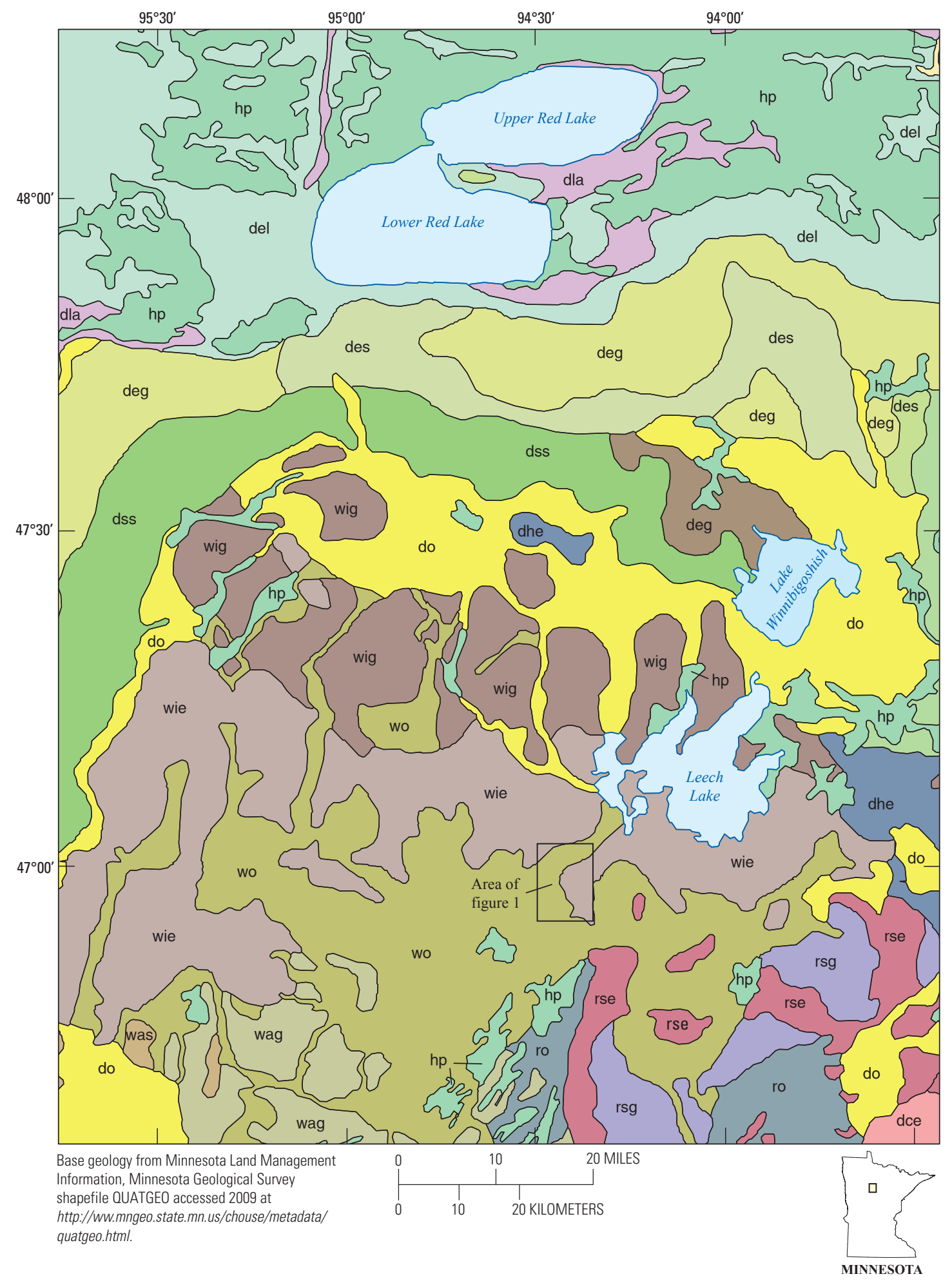

Figure 4. Quaternary geology of the Shingobee region, north-central Minnesota. 


\section{EXPLANATION}

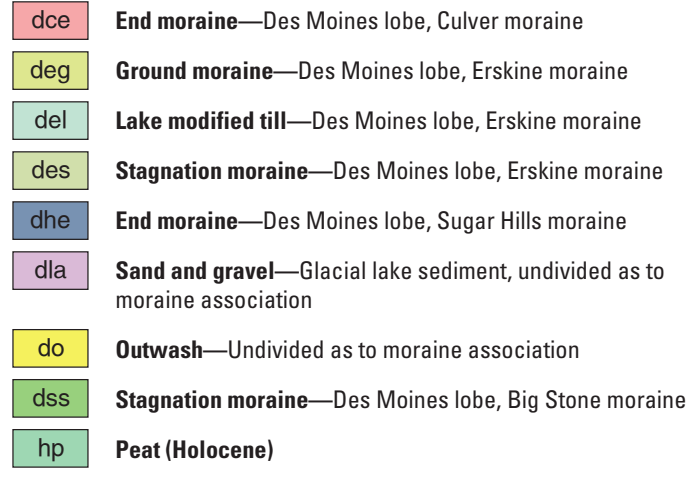

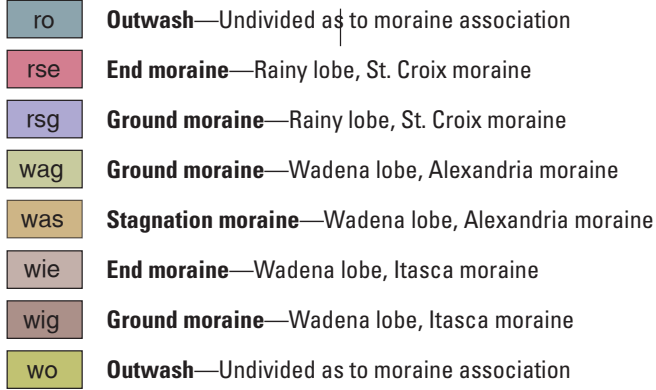

Figure 4-Continued. Adapted from Hobbs and Goebel (1982), Minnesota Department of Administration (1987), and Minnesota Geological Survey and Minnesota Department of Health (2010).
Hewitt phase deposits in the Shingobee headwaters area include ground moraine and drumlins draped by meltout tills and outwash deposited as the ice waned. Hewitt deposits dominate the southern and southwestern parts of the map area (units hgm, ho) (fig. 1).

\section{Stratigraphy and Regional Geologic Setting}

North-central Minnesota is bordered by the Big Stone and Erskine moraines to the north and west, the St. Croix moraine on the east, and the Alexandria moraine on the south and southwest (figs. 3, 4). The general distribution of major till bodies within the Shingobee region is shown in figure 4 . Distribution of major moraines in the immediate vicinity of the Shingobee headwaters is shown in figure 7 (boundaries are approximate), as is regional stratigraphy.

By using stratigraphic position and lithology, deposits at Shingobee can be correlated with previously named stratigraphic units in northwest Minnesota (stratigraphic column, fig. $7 B$ ). The oldest unit is the Marcoux Formation (correlative unit hgm, fig. 1). It consists mostly of ground-moraine facies deposited during the Hewitt phase. The Marcoux Formation is an important aquifer in the region. The overlying St. Hilaire Formation has no correlative units in the Shingobee headwaters area but is widespread north and northwest of the Itasca moraine. It consists of a discontinuous array of lake deposits, probably accumulated in marginal lakes along the front of retreating Hewitt ice during the Hewitt-Itasca interstade. Where present, the St. Hilaire Formation acts as a confining layer over the Marcoux aquifer. The lower part of the Red Lake Falls Formation (correlative units ito and its, fig. 1) consists mostly of tills of the Itasca phase. The lower Red Lake Falls Formation is a major unconfined aquifer in the northern parts of the Shingobee region. The Des Moines glaciation deposited the upper part of the Red Lake Falls Formation, another unconfined aquifer, which is absent in the Shingobee area but widespread to the north (Des Moines lobe, figs. 3, 4). The basic sequence in the Shingobee region is as follows: Itasca phase till (lower Red Lake Falls Formation) overlies Hewitt till (Marcoux Formation) north of the Itasca moraine and it, in turn, is overlain by Des Moines lobe till (upper Red Lake Falls Formation) north of the Bemidji area (figs. 3, 7).

Rainy lobe tills east and southeast of the Itasca moraine are more or less contemporaneous with those of the Wadena lobe but are confined to the area east of the St. Croix moraine (figs. 3, 4, 7). During Hewitt and Itasca phases, no tills having a Rainy lobe lithology were deposited in the Shingobee headwaters area.

The east-west-trending Itasca moraine (Wadena lobe, Itasca phase) extends westward about $80 \mathrm{~km}(50 \mathrm{mi})$ from the Shingobee headwaters, where it is crosscut by the late Wisconsin Big Stone moraine of the Des Moines lobe (fig. 3). About $12 \mathrm{~km}(7 \mathrm{mi})$ to the east, near the town of Hackensack (fig. $2 A$ ), the Itasca moraine terminates against the contemporaneous Rainy lobe, St. Croix moraine (figs. 3, 5B, 7). Older Hewitt phase tills lie both south and west of the limits of the Itasca moraine. Where not buried by younger deposits associated with the Big Stone and St. Croix moraines, Hewitt tills are found as far southwest as the Alexandria moraine (fig. 3). Large tunnel valleys (as the term is used by Wright, 1973, 1993; Hooke and Jennings, 2006; Jørgensen and Sandersen, 2006) traverse the Shingobee region from north to south (fig. 8) and are characteristic features of both Hewitt and Itasca lobe till units.

North of the Itasca moraine (figs. 4, 7) surficial deposits are mostly Itasca ground moraine draped by supraglacial meltout till (as described by Dreimanis, 1989) and marked by numerous tunnel valleys (Hobbs and Goebel, 1982; Wright, 1993) (figs. 5, 8). These deposits are exposed between the eastern side of Leech Lake and the north-south axes of the Alexandria and Big Stone moraines about $50 \mathrm{~km}(31 \mathrm{mi})$ to the west (fig. 3). During maximum extent of the Itasca phase ice, tunnel valleys carried meltwater from the area of the Red 

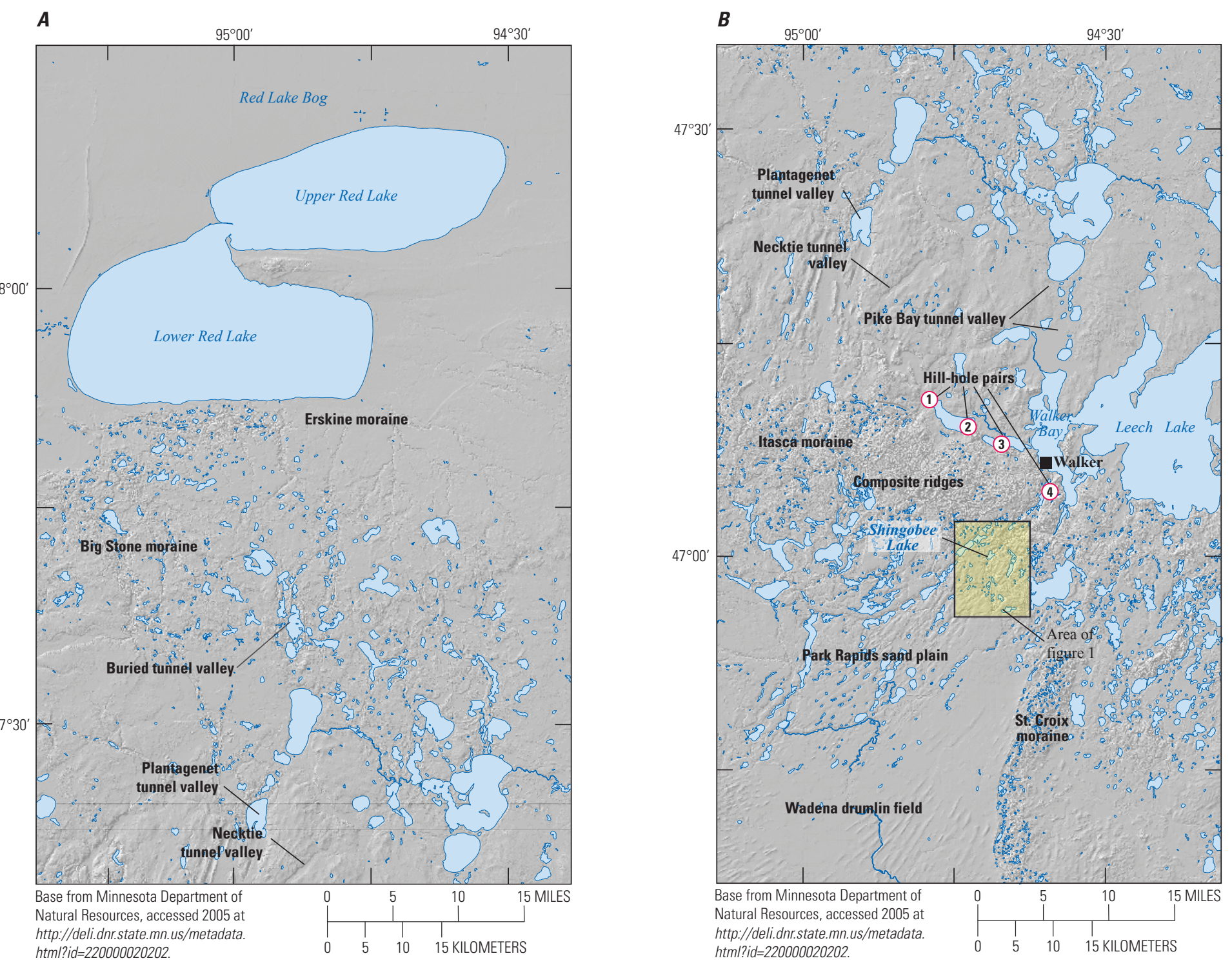

Figure 5. Prominent geomorphic features mentioned in the text. $A$, North part of Shingobee region. $B$, South part of Shingobee region. Circled numbers lie on the northwest corner of hill parts of four hill-hole pairs: (1) Kabekona, (2) Benedict Lake, (3) Kabekona Bay, and (4) Ah-Gwah-Ching. Source: Minnesota Department of Natural Resources (2010). 


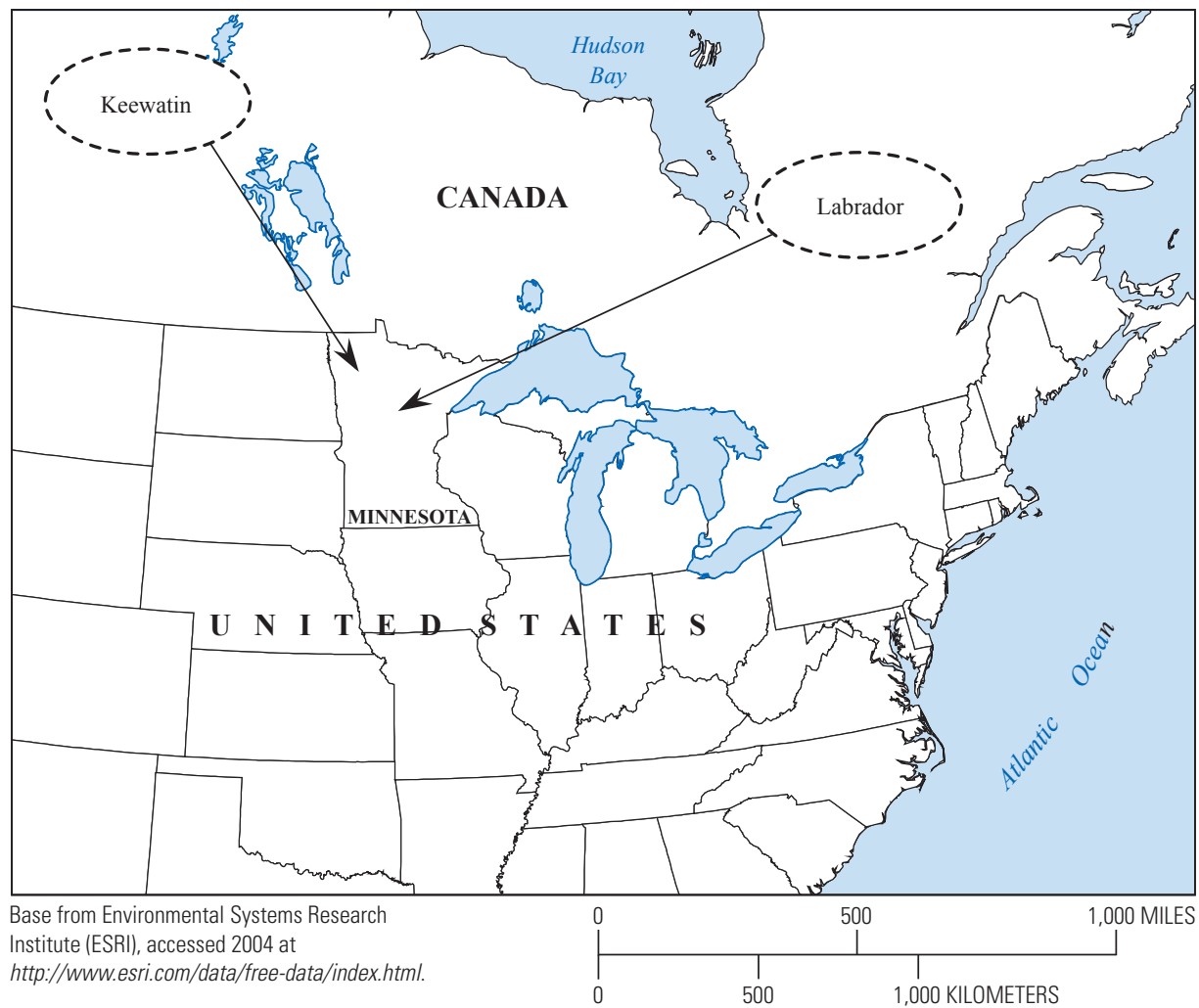

Figure 6. Accumulation centers of Laurentide ice sheets that entered Minnesota during late Wisconsin time. (Adapted from Wright, 1972; Mooers and Lehr, 1997.)

Lakes (fig. 5) southward about $100 \mathrm{~km}(62 \mathrm{mi})$ to the Itasca moraine. Even more extensive subglacial drainage occurred when the Hewitt phase attained its maximum extent, and drainage systems extended from the Red Lakes (fig. 5) to the vicinity of the Alexandria moraine (fig. 3, unit was), a distance of about $225 \mathrm{~km}(139 \mathrm{mi})$.

The Park Rapids sand plain (fig. 5B; fig. 4, unit wo), south and west of the Shingobee headwaters, is an extensive outwash body of braided stream sediments, at least locally derived mostly from the Itasca moraine (fig. $5 B$ ). Throughout its total extent, this feature has a mixed provenance representing most phases of the Wadena and Rainy lobes (Hewitt and Itasca phases, St. Croix phase) and in its western parts, possibly Des Moines lobe deposits as well. In the Shingobee region, outwash partially obscures the expression of the older Hewitt phase Wadena drumlin field. The St. Croix moraine of the Rainy lobe forms the southeastern border of the region (Hobbs and Goebel, 1982; Mooers and Norton, 1997) (figs. 3, 5B).
Table 1. Dates of principal glacial events in the Shingobee region, north-central Minnesota.

[Dates are calendar years based on ice core accumulation-layer counts. $<$, less than; ka, kiloannum, thousand years ago; k.y., thousands of years]

\begin{tabular}{lcc}
\hline \multicolumn{1}{c}{ Event } & \multicolumn{1}{c}{$\begin{array}{c}\text { Age } \\
\text { (ka) }\end{array}$} & $\begin{array}{c}\text { Duration } \\
\text { (k.y.) }\end{array}$ \\
\hline $\begin{array}{l}\text { Des Moines glaciation } \\
\text { (Younger Dryas) }\end{array}$ & 13.5 to 11.6 & 1.9 \\
$\begin{array}{l}\text { Itasca-Des Moines interstade } \\
\text { (Bølling) }\end{array}$ & 14.7 to $<13.5$ & 1.2 \\
$\begin{array}{l}\text { Itasca phase (Wadena lobe) } \\
\text { glaciation }\end{array}$ & 22.8 to $<14.7$ & 8.1 \\
$\begin{array}{l}\text { Hewitt-Itasca interstade } \\
\text { Hewitt phase glaciation }\end{array}$ & 23.6 to $<22.8$ & 0.8 \\
Pre-Hewitt interstade & 27.2 to $<23.6$ & 3.6 \\
\hline
\end{tabular}




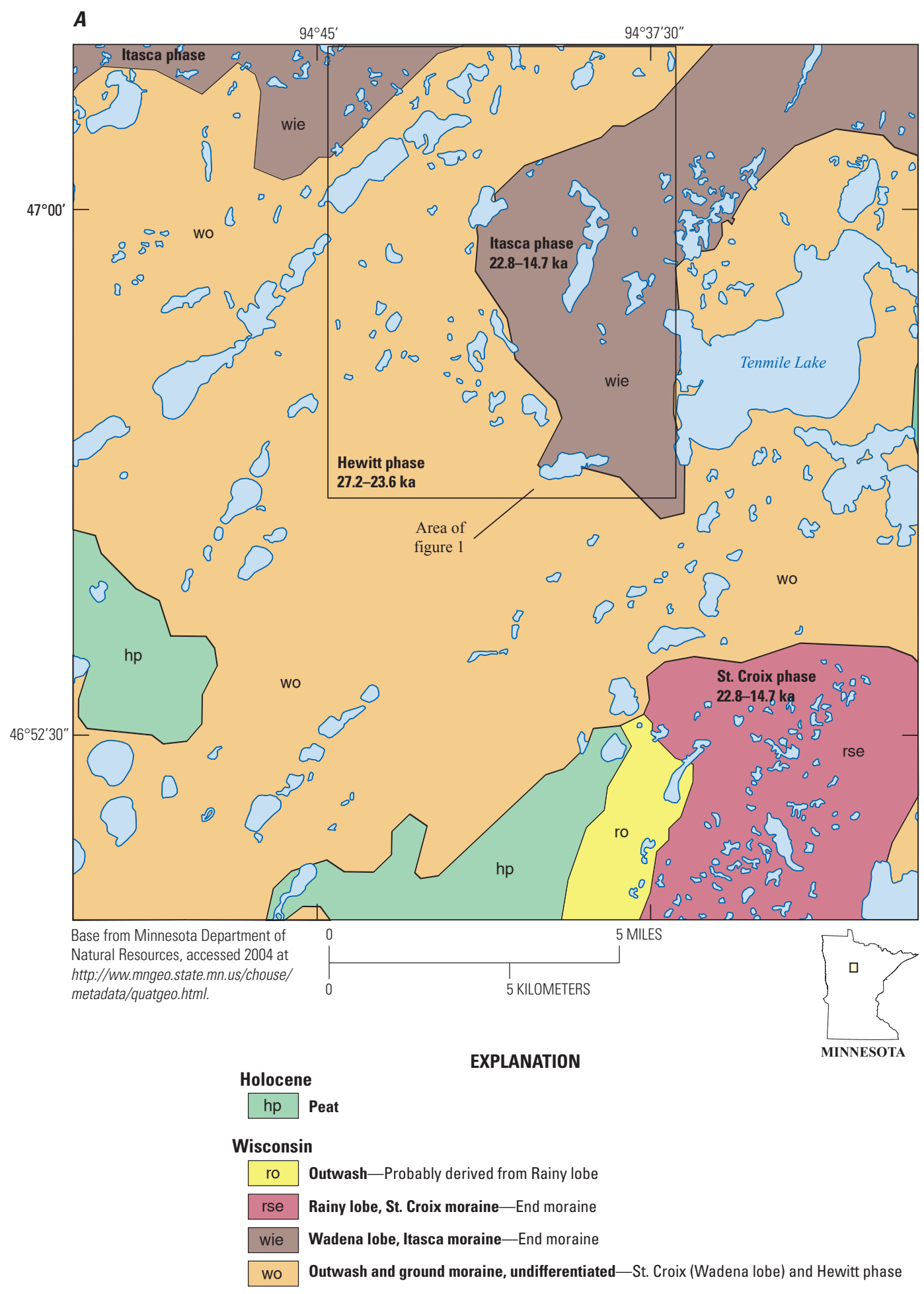

Figure 7. A, Generalized distribution of till bodies in the Shingobee headwaters area. Dates of Rainy lobe tills are estimated. Boundaries of till bodies are approximate and based on Hobbs and Goebel (1982). Each till unit contains ground moraine, terminal moraine, and outwash facies. 


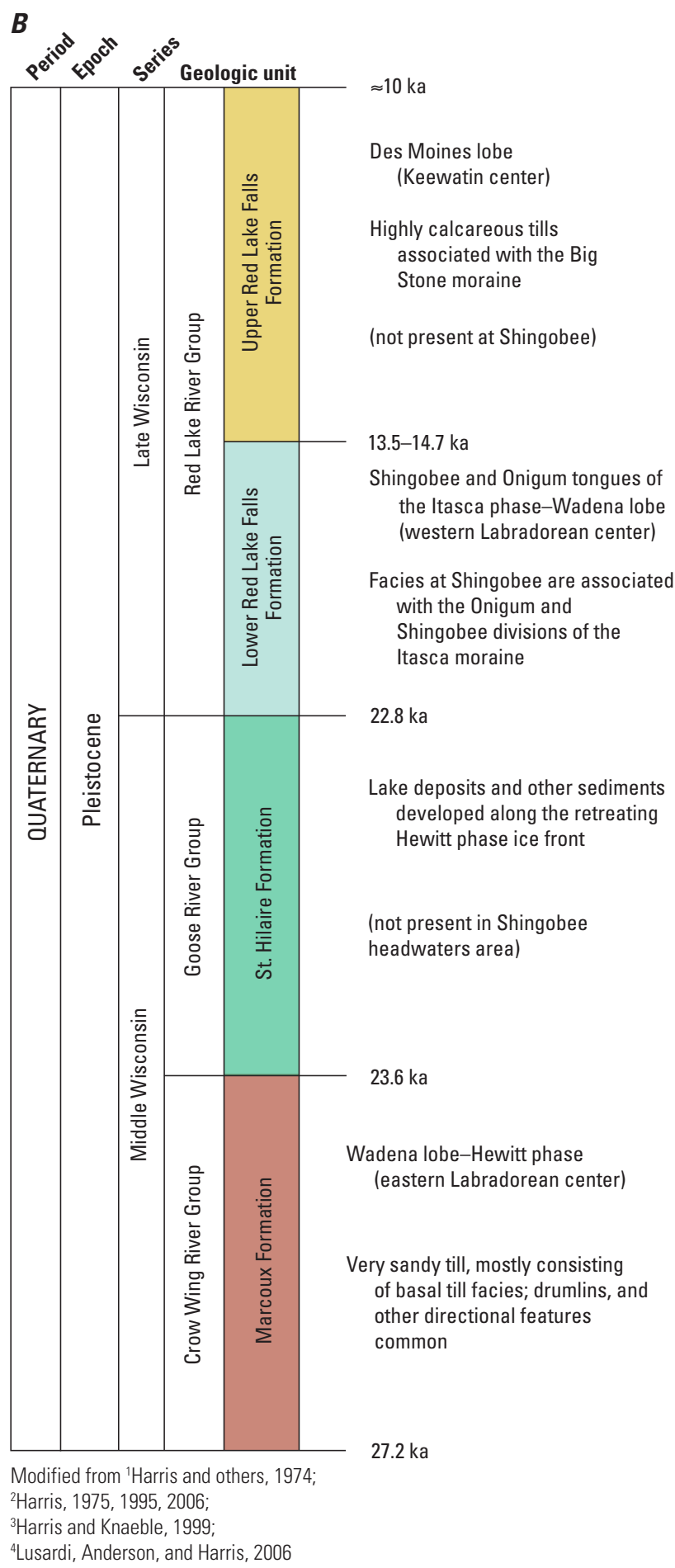

Figure 7-Continued. B, Composite section encompassing the entire Shingobee region. Source: Minnesota Geological Survey and Minnesota Department of Health (2010) and Minnesota Department of Natural Resources (2010). (ka, thousand years old.)

\section{Sedimentology and Topographic Features}

Ten map units are shown on figure 1. They are described below by deposit type in stratigraphic sequence, from oldest to youngest. Relations with lake deposits within the sequence are discussed where appropriate.

\section{Hewitt Phase Ground Moraine (Unit hgm)}

Ground moraine (in its broad sense; see Flint, 1971) of the middle Wisconsin Hewitt phase is the oldest exposed sedimentary unit in the Shingobee region and constitutes most of the land surface in the north-central and western parts of the Shingobee headwaters map area (figs. 1, 9). Deposits present a topographic continuum ranging from large, elongate drumlins to small, approximately circular mounds and swales (Mooers and Norton, 1997; Winter and Rosenberry, 1997) (figs. 1, 9).

Drumlins with elongation ratios approaching those of megaflutes (Clark, 1993, 1994) or streamline hills (Rose, 1987) are found in the southwest part of the area (figs. 1, 9, 10). These features generally have long axes striking north to northeast and form a topographic fabric parallel to the presumed axis of Hewitt ice flow. A few kilometers southwest of the mapped area, they increase in size and length and may be as much as $3 \mathrm{~km}$ (1.9 mi) long, $750 \mathrm{~m}(0.48 \mathrm{mi})$ wide (length:width ratio, 4:1), and about $20 \mathrm{~m}(66 \mathrm{ft}$ ) high. Drumlins south and west of the Shingobee headwaters area have long axes that generally trend northeast-southwest and are separated by swales that typically contain wetlands and shallow lakes.

Smaller hills, less elongated than the drumlins (average dimensions $420 \times 250 \mathrm{~m}(1,378 \times 820 \mathrm{ft})$; length:width, about $2: 1$ ), whose long axes are somewhat variable in trend from northeast- southwest to northwest-southeast, are found in the west-central part of the area (unit hgm, figs. 1, 9). These low hills transition to small (tens of meters), irregularly shaped mounds and swales that are evident near the Itasca moraine (unit its) as shown in the northwest corner of figures 1 and 9. These latter features may be the result of Itasca phase modification of unit hgm by permafrost along the margin of the Itasca moraine (see section, Terminal Moraines of the Itasca Phase, Units ito and its), or of minor marginal deposition from the Itasca ice (see Mooers and Norton, 1997). Local relief ranges from $5 \mathrm{~m}(16 \mathrm{ft})$ in the small mounds and swales to about 10-15 m (33-49 ft) among the intermediate forms. Slopes of the intermediate forms are mostly well below the angle of repose, (that angle to the horizontal above which the slope is unstable, commonly $33-37^{\circ}$, American Geosciences Institute, 2013), (about $3.6 / 100$ or 0.04 ) but are quite variable between steep (at the angle of repose) and gentle (nearly those of ground moraine) within the small mounds and swales. 


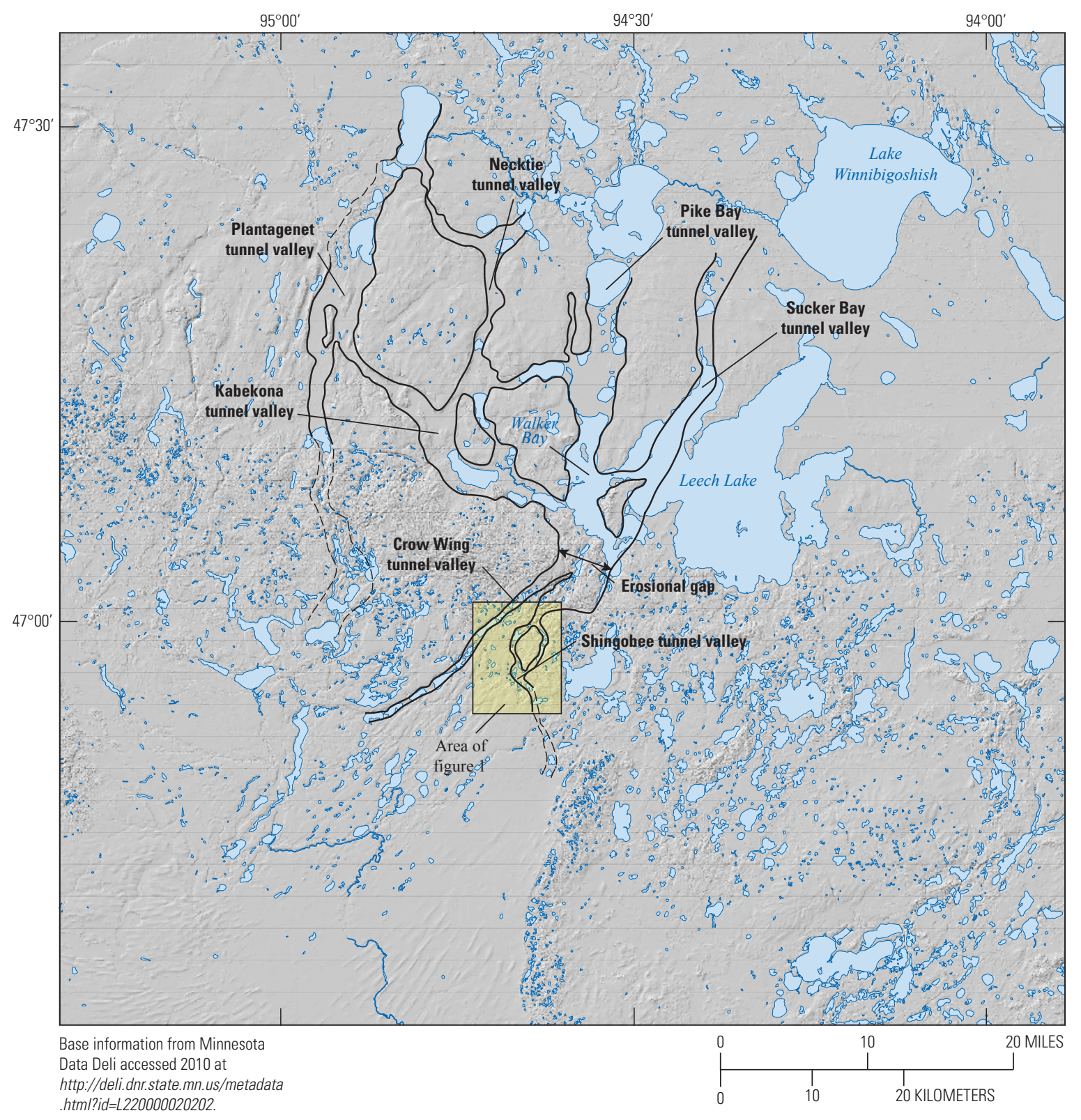

EXPLANATION

Boundary of tunnel valley-Dashed where uncertain

Figure 8. Principal tunnel valleys developed during the Itasca phase, beneath the Wadena lobe glacier that covered the Walker Bay area of Leech Lake. Source: Minnesota Department of Natural Resources (2010).

Sediment textures in Hewitt ground moraine range from gravelly sands to massive silts, reflecting a variety of depositional modes beneath Hewitt ice. Finer-grained exposures may consist of massive, poorly sorted, compact, sandy silts with scattered, rounded pebbles, cobbles, and larger rock fragments. In some locations, however, laminated, moderately well sorted silts or silty sands, free of larger rock fragments (a sedimentary suite which suggests deposition in lakes) are present (see Lake Deposits section). The most common of the fine-grained deposits within Shingobee ground moraine areas are of the first type. The matrix has a modal grain size in the range of fine-grained sand to coarse silt, skewed to coarser sizes. Most exposures are massive or poorly graded and a meter or more thick. These deposits are interpreted as meltout tills (as used by Evans and others, 2006). The second, more variable, type of fine-grained unit may have originated in one of several ways: subglacial cavities, collapsed supraglacial ponds, postglacial lakes, cryoturbation, or loess. Silts and silty sands of the second type are common in the small mound-and-swale topography found along the front of the Itasca moraine and in the area between the Shingobee tunnel valley (units htv1, htv2) and Howard Lake (figs. 1, 9). Coarse, mostly sandy, 


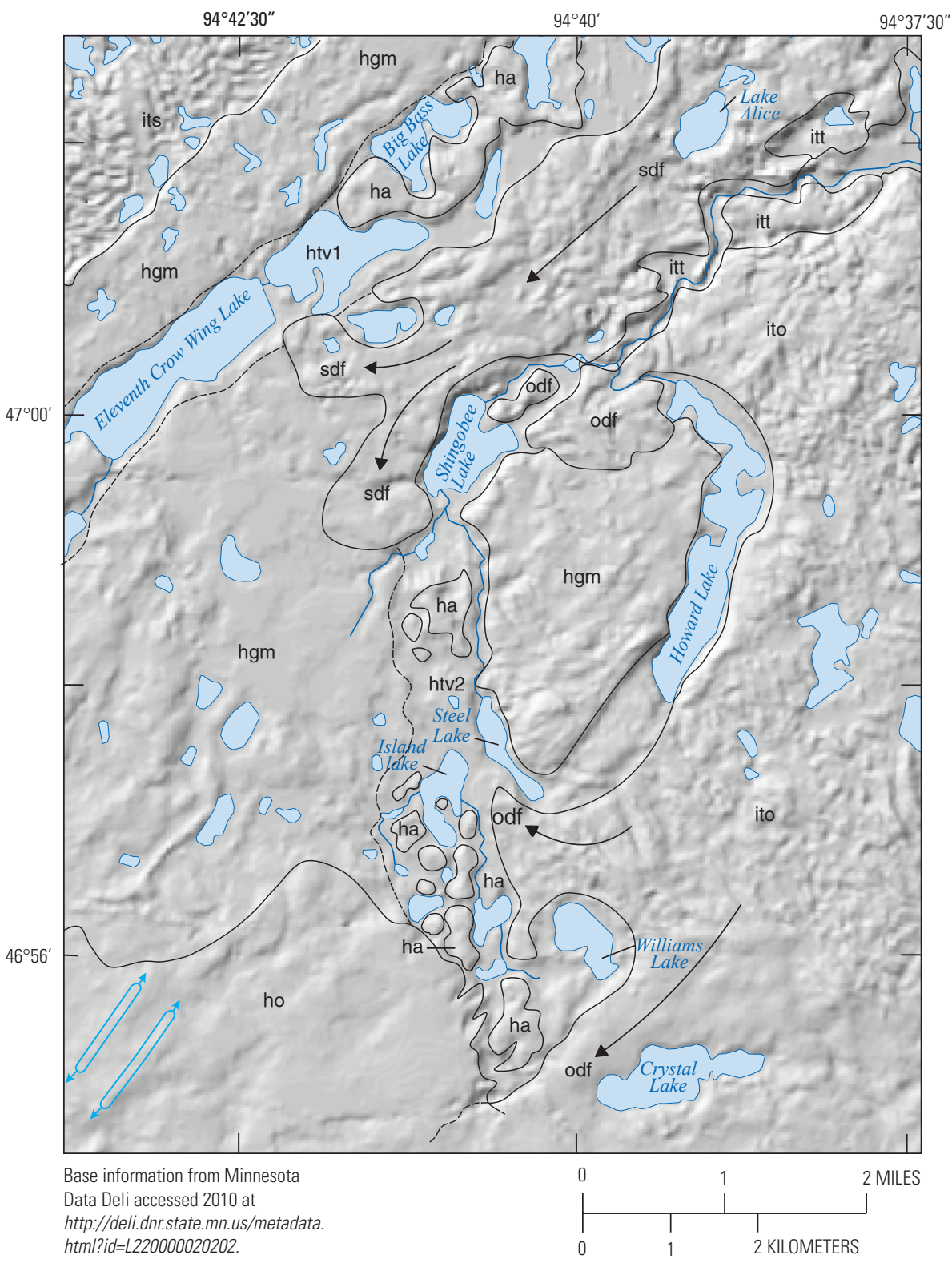

\section{EXPLANATION}

$\longrightarrow$ Debris flow-Axis of general motion

\section{Tunnel valley margin}

Unit boundary—Dashed where uncertain

Drumlin

\section{LIST OF MAP UNITS}

\section{Itasca phase deposits}

itt Stream terrace-Formed during the late stages and after the completion of the Itasca phase present to $<14.7 \mathrm{ka}$

sdf Debris flow_-Proglacial run-outs that originated from the Shingobee division of the Itasca moraine, $<14.7 \mathrm{ka}$

Debris flow—Proglacial run-outs that originated from the Onigum division of the Itasca moraine $<14.7 \mathrm{ka}$

Shingobee division of the Itasca moraine-Highly variable sediments, mostly derived from debris and mudflows produced on the margin of the Shingobee tongue of the Itasca phase glacier, 14.7-22.8 ka inclusive

Onigum division of the Itasca moraine - Highly variable sediments, mostly of debris and mudflow origin, produced on the margin of the Onigum tongue of the Itasca phase glacier, 14.7-22.8 ka inclusive

\section{Hewitt phase deposits}

ha Hewitt phase kame-Primarily poorly bedded gravels and sands that were deposited among collapsed ice blocks in subglacial tunnel valleys during disintegration of the Hewitt glacier Approximate age, $23.5 \mathrm{ka}$

ho Hewitt phase outwash-Well-sorted sands and gravels deposited at the end of the Hewitt glaciation, $\approx 23.5 \mathrm{ka}$

htv1/htv2 Tunnel valley-Originated during Hewitt glaciation; many remained active throughout the subsequent Itasca phase, 14.7-27.2 ka

hgm

Hewitt ground moraine-Sands and a few silts deposited at the base of the Hewitt phase glacier, characteristically sandy with intercalated gravel beds, $>23.6 \mathrm{ka}$

Figure 9. Approximate distribution of Hewitt and Itasca phase glacial deposits in the Shingobee headwaters area. Permafrost features (mottled terrain in the northwest corner of the figure) are mapped with Itasca phase terminal moraine because they are closely associated. All other map units in this figure contact or overlie Hewitt ground moraine (hgm). Note southwest-northeast-trending fabric of exposed Hewitt phase ground moraine (hgm). Source: Minnesota Department of Natural Resources (2010). (<, less than; >, greater than; ka, kiloannum.) 


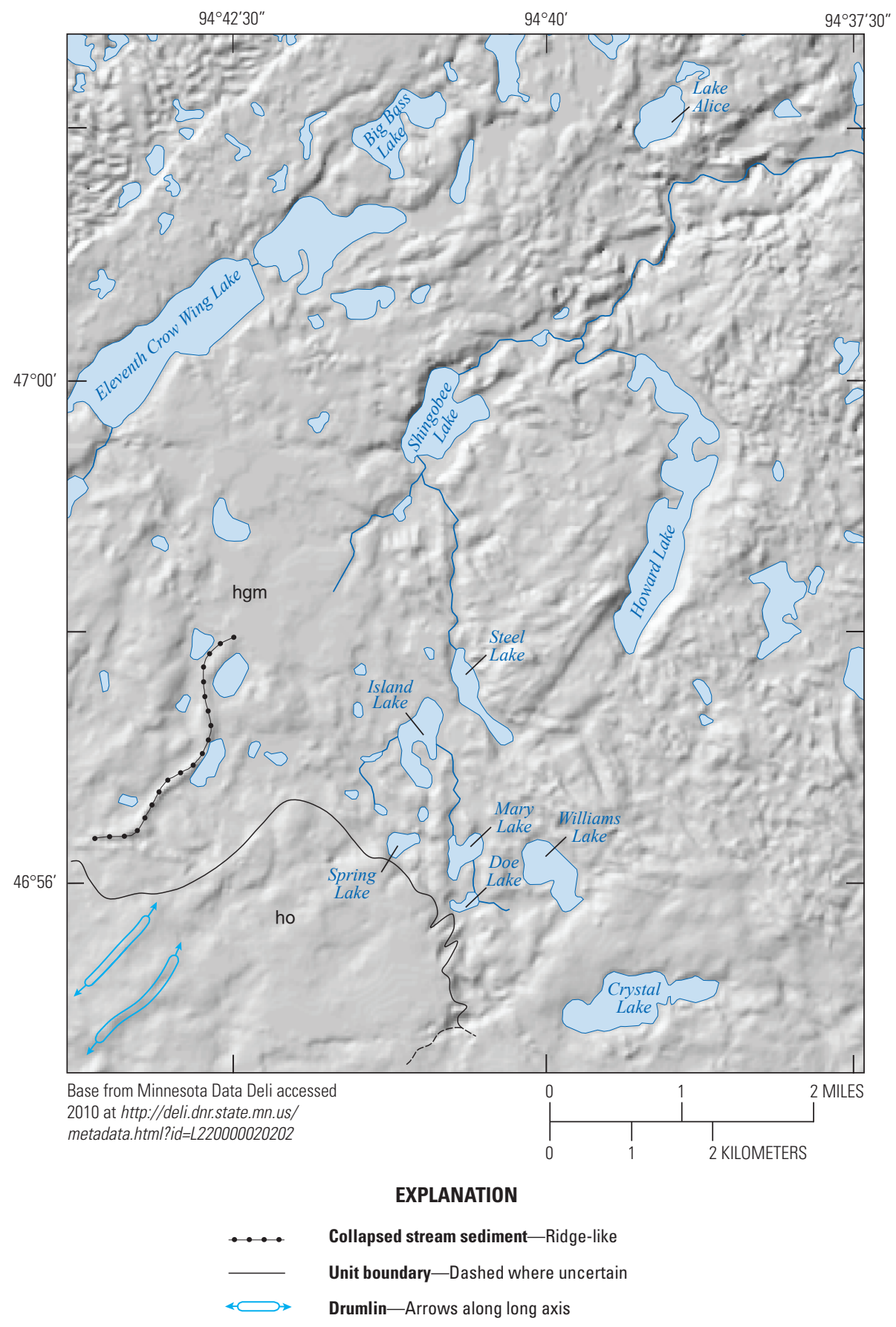

LIST OF MAP UNITS

Hewitt phase deposits

ho Hewitt phase outwash-Well-sorted sands and gravels deposited at the end of the Hewitt glaciation, about $23.5 \mathrm{ka}$

hgm Hewitt ground moraine-Sands and a few silts deposited at the base of the Hewitt phase glacier, characteristically sandy with intercalated gravel beds, older than $23.6 \mathrm{ka}$

Figure 10. Approximate distribution of Hewitt phase outwash and ground moraine in the Shingobee headwaters area. An inverted stream channel, or perhaps a small esker, of about the same age as the outwash is shown for comparison with outwash-draped drumlins in the area. The southeastern boundary of the outwash merges imperceptibly with Itasca phase outwash. Source: Minnesota Department of Natural Resources (2010). 
deposits associated with units sdf and odf (figs. 1,9) are found among intermediate-size hills in the north-central parts of the area. Typically, these sediments are poorly to moderately sorted, mostly sandy (fine to medium sand, skewed to coarser sizes (coarse sands) with pebbles, cobbles, or small boulders but little silt. The beds are associated with lobate debris flows from the Itasca moraine, but they also resemble basal meltout till (Nobles and Weertman, 1971; Lawson, 1981; Shaw, 1985). The lack of fines in these deposits suggests some degree of sorting by meltwater during deposition (Shaw and Sharpe, 1987; Shaw, 2002). Bedding tends to be vague but, where seen, generally consists of poorly graded and, at some locations, reverse graded sands and gravels. Southwest-trending lag boulder trains may be found on the flanks of drumlins and in swales (fig. 1).

\section{Late Hewitt Phase Outwash (Unit ho)}

A topographically flat outwash body (unit ho) overlies Hewitt phase ground moraine (unit hgm) in the southwestern part of the Shingobee region (figs. 1, 10). Local relief on the outwash is less than $15 \mathrm{~m}$ (49 ft), and slope angles (about $2 / 100$ or 0.02 ) are well below the angle of repose. Maximum elevation of the outwash is about $462 \mathrm{~m}(1,515 \mathrm{ft})$, exceeding that of adjacent exposed ground moraine by as much as $15 \mathrm{~m}$ $(49 \mathrm{ft})$. The outwash deposits consist of sequences of moderately well sorted, medium-grained sands in poorly bedded strata. Laterally extensive (hundreds of meters), matrixsupported, pebble-rich beds are intercalated with the sands. Silt, cobbles, and boulders are absent. The outwash unit pinches out about a mile $(1.6 \mathrm{~km})$ west of the map area but thickens both to the south and northeast. Well logs suggest that the outwash is as much as $20 \mathrm{~m}(66 \mathrm{ft})$ thick along the southern edge of the Shingobee mapped area (figs. 1, 10) and 21-28 m (69-92 ft) in the central part (Minnesota Geological Survey and Minnesota Department of Health County Well Index, 2010). Individual beds range from 0.3 to $0.6 \mathrm{~m}$ (1-2 ft) thick. A supraglacial, inverted stream-channel segment or, perhaps, a small esker, is apparent as a southwest trending ridge (figs. 1, 10) close to the northwest margin of the outwash body.

The outwash body (unit ho, figs. 1, 10) appears to have been deposited in both supraglacial and proglacial positions. Where the beds were supraglacial, they draped onto the underlying subglacial topography as the ice melted. This relationship is suggested by buried structures, possibly drumlins, that conform to the northeast-southwest orientation of the general topographic trend. These features are seen in the southwestern portion of figures 1 and 10. The west edge of the unit (about a mile west of the map area) appears proglacial because it pinches out between drumlins (rather than covering them) west of the map area. Slumped margins of the outwash near the angle of repose (slope about 0.3 ), however, formed on the north and east sides of unit ho, just south of the "esker," eastward to the vicinity of Doe Lake (fig. 10). The slumped margins may mark the position of confining ice-wall boundaries that were part of the retreating Hewitt phase ice. These abrupt slopes further suggest an ice-marginal or supraglacial position for this part of the outwash. To the west and south, the outwash blends with the Park Rapids sand plain and its boundaries become unclear (figs. 1, 5B).

Mooers and Norton (1997) assign this outwash to the Itasca phase. The steep, slumped margins on the north and east sides, however, suggest ice contact and appear more consistent with a Hewitt phase origin since the Itasca moraine front is relatively distant (about 2 to $3 \mathrm{~km} ; 1-2 \mathrm{mi}$ ) northwest of the outwash area. Pinched-out margins to the southwest, buried drumlins, and a wedge-like thickening of the unit to the north and east are consistent with a source from Hewitt phase ice during the waning stages of the Hewitt glacial advance.

\section{Late Hewitt Phase Kames (Unit ha)}

Between Shingobee Lake and Williams, Mary, and Island Lakes (fig. 1), a number of kames dot the floor of the Shingobee tunnel valley (fig. 11). These features are as much as 20 $\mathrm{m}(66 \mathrm{ft})$ high and $0.2-1.8 \mathrm{~km}(650 \mathrm{ft}-1.1 \mathrm{mi})$ long. Northwest of Williams Lake, kames are interspersed with small ice-block depressions containing small lakes, shallow ponds, and swamps (referred to as glacial karst, Clayton, 1964). The kames appear to have formed by meltwater deposition among ice blocks from a collapsed segment of tunnel roof. Except for a few thin beds of moderately well sorted fine sand, sediments are pebbly to sandy and poorly sorted. Most beds have a median grain size in the medium- to coarse-sand range. Bedding thickness is generally in the range of 2.5-20 centimeters $(\mathrm{cm})(1-8$ inches (in.) with well-defined upper and lower contacts. Cross bedding is seen in some of the fine-sand units. In most exposures, bedding has been tilted and deformed by slumping. The kames formed during the disintegration stages of Hewitt phase glaciation.

\section{Lake Deposits (Unit itl)}

The Shingobee region contains lake deposits of two types: isolated, small, relatively thin deposits and more widespread deposits, generally associated with tunnel valleys. Scattered, small lake deposits are found mostly on Hewitt ground moraine within glacial-lake boundaries (fig. 12). Most of these smaller lakes were formed by high-stand flooding during glacial lake Willobee time (about 14-16 ka) (fig. 12), near the conclusion of the Itasca phase (Dean and Schwalb, 2002). The deposits of other lake and pond systems are of uncertain origin and are not mapped because of their small size and vague boundaries. Some of these smaller deposits may have formed in melt basins on post-Hewitt phase permafrost, others may have had a proglacial or supraglacial origin during Hewitt time, and still others may have formed in post-Itasca phase settings during Des Moines glaciation. 


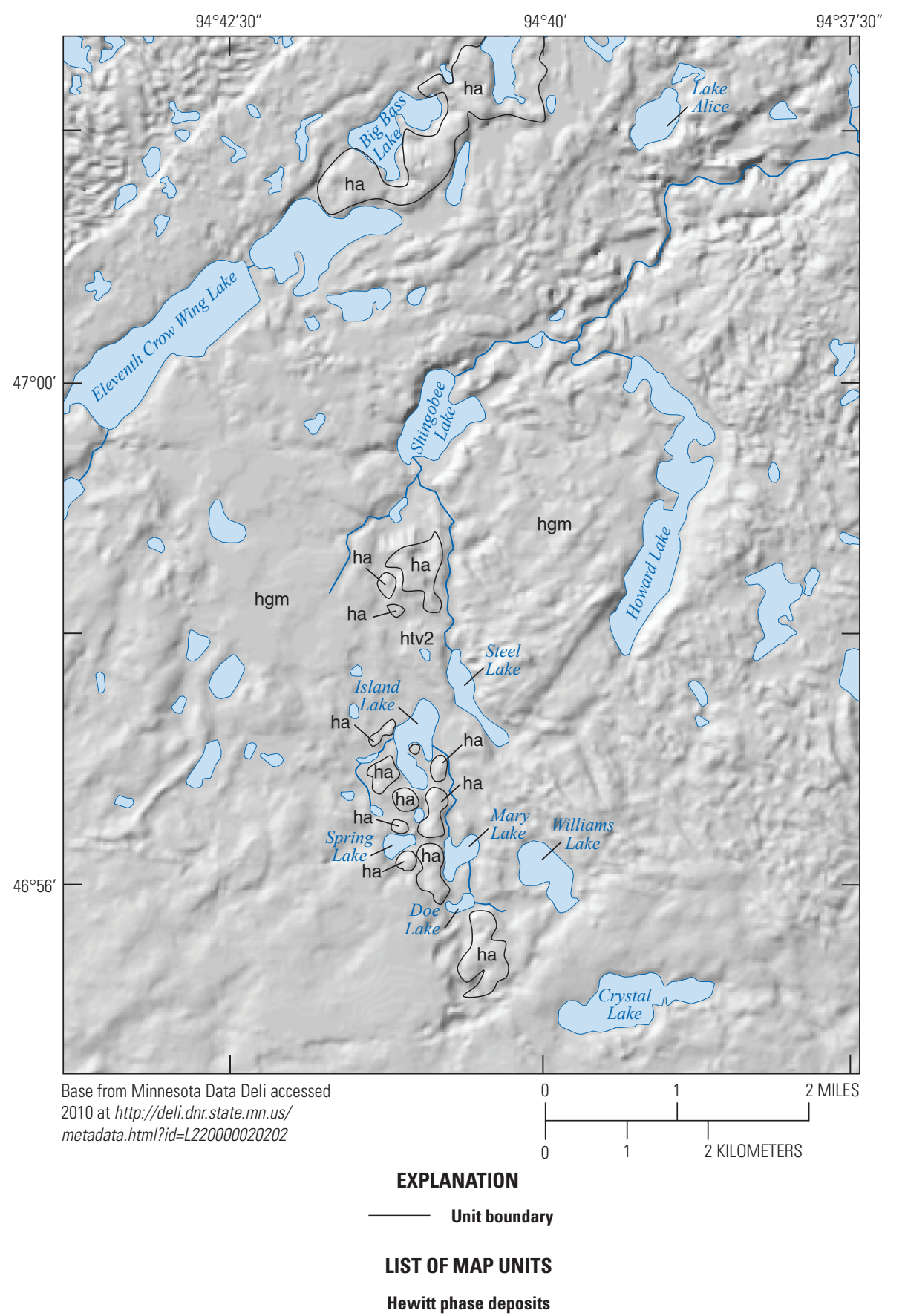

ha Hewitt phase kame-Primarily poorly bedded gravels and sands deposited among collapsed ice blocks in subglacial tunnel valleys during disintegration of the Hewitt glacier. Approximate age, $23.5 \mathrm{ka}$

htv2 Tunnel valley-Originated during Hewitt glaciation; many remained active throughout the subsequent Itasca phase, 27.2-14.7 ka

hgm Hewitt ground moraine-Sands and a few silts deposited at the base of the Hewitt phase glacier, characteristically sandy with intercalated gravel beds, older than $23.6 \mathrm{ka}$

Figure 11. Approximate distribution of Hewitt phase kames (unit ha) in Crow Wing and Shingobee (unit htv2) tunnel valleys and Hewitt phase ground moraine in the Shingobee headwaters area. Kames were emplaced as the Hewitt phase waned. Their positions were controlled by ice blocks that collapsed from the tunnel roof. Source: Minnesota Department of Natural Resources (2010). 


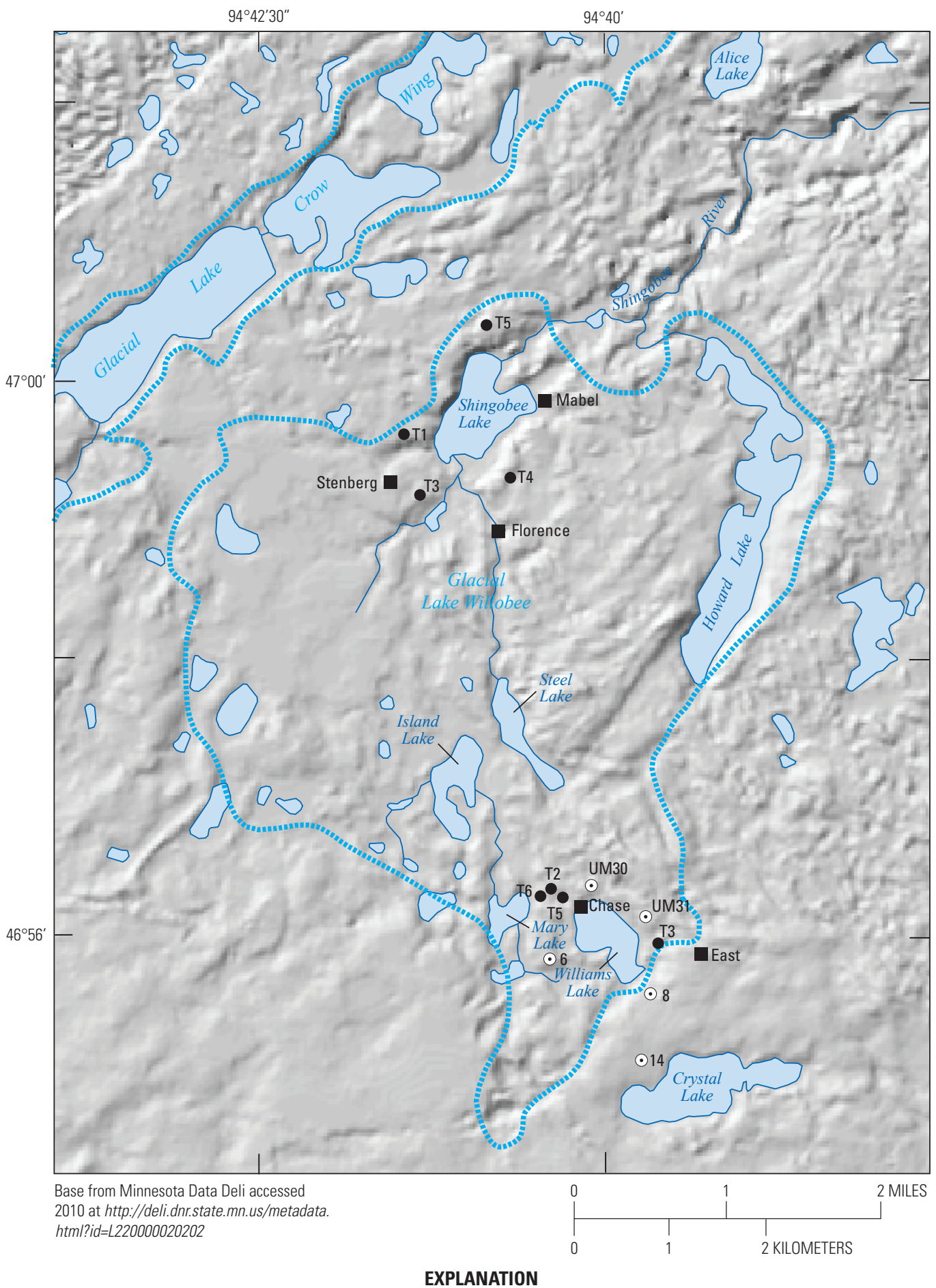

Approximate high-stand shoreline of glacial lake

- T1 Test well and number

$\odot$ UM30 Water sampling well and number

Figure 12. Approximate limits of glacial lakes Willobee and Crow Wing in the Shingobee headwaters area and positions of test holes used in this report. Lake deposits are various and scattered within the dashed lines representing maximum extent of Crow Wing and Willobee lakes. Several wells around Crystal Lake are not shown because well logs did not give precise locations. Source: Winter and Rosenberry (1997), Minnesota Department of Natural Resources (2010). 
Larger-scale deposits are formed in glacial lakes within and near the boundaries of the Shingobee tunnel valley, glacial lake Willobee (name derived by combining names of Shingobee and Williams Lakes; Schwalb and Dean, 2002) and the Crow Wing tunnel valley (figs. 8, 12). Glacial lake Willobee deposits are thickest (about 30-40 m (100-130 ft)) in the Shingobee tunnel valley but are absent or thin (about 1-2 m $\left(3 \frac{1}{4}-6^{1 / 2} \mathrm{ft}\right)$ ) elsewhere in the area (fig. 9); locally these thin deposits may cover hundreds of square meters. Glacial lake Willobee deposits are extensive and may be relatively thick, whereas those of glacial lake Crow Wing are thin, discontinuous, and confined to the Crow Wing tunnel valley. Glacial lake Willobee formed after the preexisting Hewitt-stage Shingobee tunnel valley was dammed by large debris flows from sources in the Itasca moraine.

Glacial lake Willobee deposits are moderately to well sorted with a median grain size in the fine-grained sand to coarse silt range. In many exposures bedding is massive, perhaps because of postdepositional reworking by wind, cryoturbation, or solifluction. Massive deposits are visible in roadcuts at latitude (lat) $47^{\circ} 0^{\prime} 9.5^{\prime \prime} \mathrm{N}$., longitude (long) $94^{\circ} 42^{\prime} 22.5^{\prime \prime} \mathrm{W}$. and at lat $46^{\circ} 57^{\prime} 46.8^{\prime \prime}$ N., long $94^{\circ} 40^{\prime} 45.6^{\prime \prime}$ W. Other locations, however, contain well-developed varves (for example, at lat $46^{\circ} 59^{\prime} 56^{\prime \prime}$ N., long $94^{\circ} 41^{\prime} 43.4^{\prime \prime} \mathrm{W}$. and at lat $47^{\circ} 0^{\prime} 9.5^{\prime \prime} \mathrm{N}$., long $94^{\circ} 40^{\prime} 48^{\prime \prime} \mathrm{W}$.). Varve couplets are $0.8 \mathrm{~cm}$ to about $1.8 \mathrm{~cm}$ (3/8-5/8 in.) thick. They consist of a brownish, fine-grained member with a lighter, tan, coarser companion. Varved sediments, situated well above the elevations of present day lakes, were deposited when glacial lake Willobee was at its maximum extent. Estimated from the thickness of varved sediments along the east side of Shingobee Lake, which at this location is about $21 \mathrm{~m}$ (69 ft), glacial lake Willobee's high stand may have been relatively long lived (about 1,700 varve years). More than 10,000 varves have been counted in lake-sediment cores from Williams and Steel Lakes (fig. 1) (Wright and others, 2004). This large number suggests that conditions favoring varve formation persisted for a considerable time after glacial lake Willobee's high-stand. Seaberg (1985) noted marl deposits on the east and south sides of Williams Lake. These marls are reported to be about $6 \mathrm{~m}$

$(20 \mathrm{ft})$ above the present lake level (426 m (1,397 ft)) and may represent near-shore deposits of glacial lake Willobee. If this is the case, a high-stand shoreline with an elevation of about 430-434 m (1,410-1,424 ft) can be assumed. This elevation incorporates the highest exposure of glacial lake Willobee sedi-

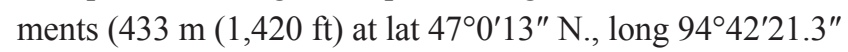
W. Because of the rarity of glacial lake Willobee's high-stand sediments, the most common limits of glacial lake Willobee deposits are mapped near the 430-m (1,410-ft) topographic contour (fig. 12).

\section{Terminal Moraines of the Itasca Phase (Units ito, its)}

Two morphologically distinct divisions of the Itasca moraine are found in the Shingobee region, one to the northwest and the other to the east (figs. 1, 13). East of the Shingobee headwaters area, deposition on the moraine is dominated by debris flow and collapsed ablation till (see "hummocky moraine" as used by Winters, 1961; see also Sharp, 1985; Benn and Evans, 1998; Boone and Eyles, 2001). Sparse linear elements mapped on the eastern side of the moraine by Mooers and Norton (1997) may be compressional features associated with the Ah-Gwah-Ching (Ojibwe, meaning "out of doors") event or, alternatively, can be identified as debris-flow fronts by their boulder concentrations, lobe-shaped elevation changes, and other evidence of shear flow (Mooers and Norton, 1997). To the west and northwest of the Shingobee headwaters, however, debris-flow and disintegration features are accompanied by extensive areas of parallel, linear ridges (Mooers and Norton, 1997) (see Aber and others, 1989; "composite moraine" in Benn and Evans, 1998; Sadura and others, 2006), a few of which contain older tills brought up from below (fig. 14). These different morphologies (figs. 13, 14) suggest pronounced differences in depositional style. To accommodate these differences in this region, this report proposes that the Wadena lobe consisted of two contemporaneous, contiguous yet independent ice tongues with dissimilar flow regimes. The Itasca moraine reflects these different flow styles by having two divisions - a western section designated as the Shingobee division (unit its) and an eastern section designated as the Onigum division (unit ito) (figs. 1, 13).

Differences in flow behavior between adjacent, contemporary ice tongues are common. Such behavior has been noted on the modern Antarctic ice sheet (Clarke, 1987; Gudmundsson, 2006) and inferred on the Laurentide ice sheet (Heinrich, 1988; Mooers and Lehr, 1997; Hooke and Jennings, 2006). A variety of reasons have been presented to explain such flow discrepancies such as differences in climate (Bond and others, 1993), subsole deformation (Clark, 1994), binge-purge cycles (MacAyeal, 1993), and subglacial sediment deformation (Winsborrow and others, 2006).

In order to produce the debris flows seen in the Shingobee headwaters area, both the Shingobee and Onigum moraine divisions required ice tongues with compressive flow or marginal ice thrusting (or both) to elevate rock debris to the ice surface (figs. 1, 14, 15). It appears, however, that ice thrust on the Shingobee side played a much greater role in the placement of moraine debris than it did on the Onigum side.

A mechanism to account for thrusting within the Shingobee moraine division involves two components. First is a large amount and wide distribution of subglacial water. A periodically wet-based Shingobee tongue is suggested by the large number of tunnel valleys along the proximal aspect of the moraine (fig. 8). From time to time, large amounts of basal meltwater delivered through the tunnel valleys appear to have influenced basal sliding by increasing the rate of ice flow and 


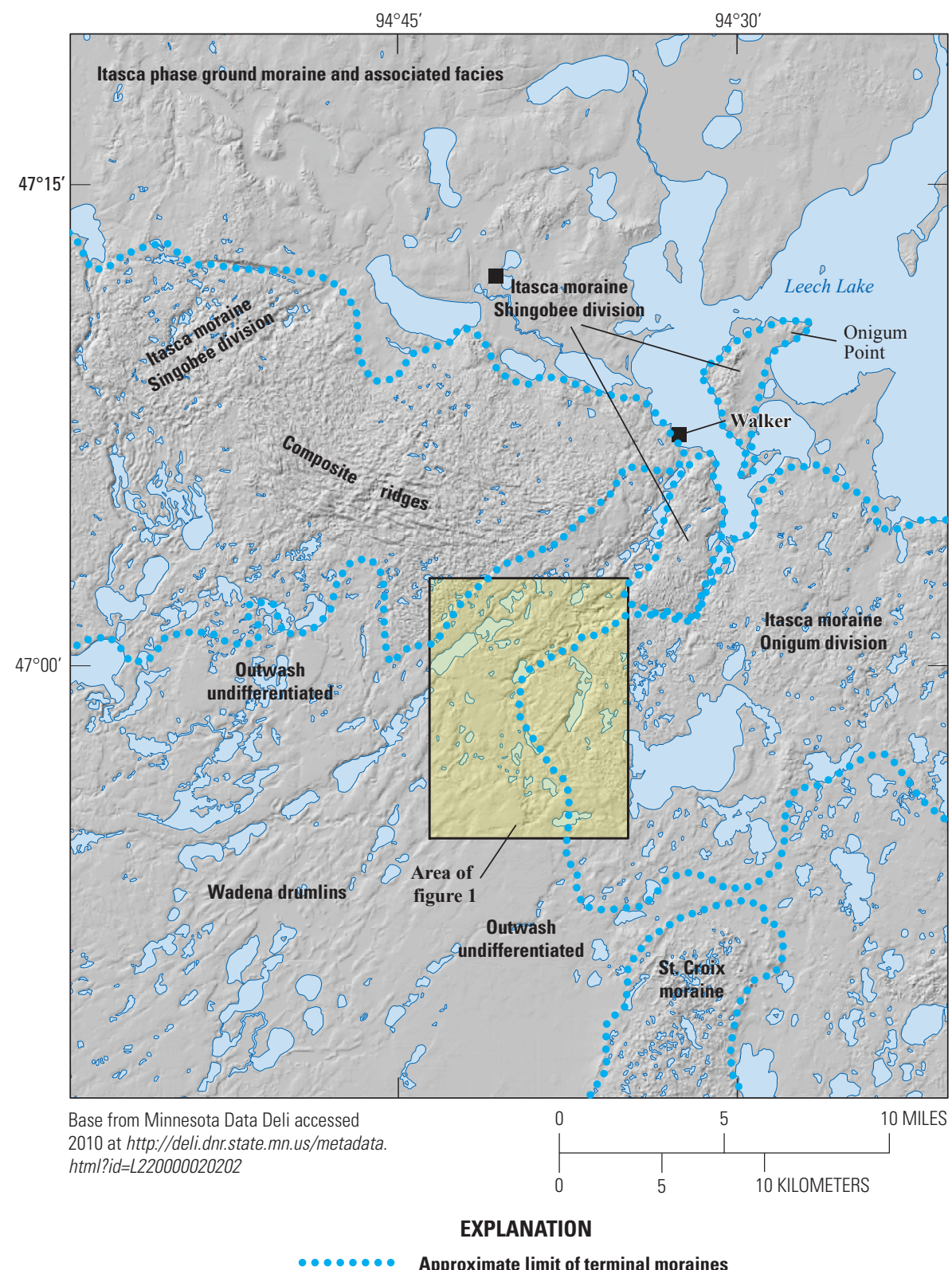

Figure 13. Approximate limits of the Shingobee and Onigum divisions of Itasca moraine in the Shingobee region. Source: Minnesota Department of Natural Resources (2010). 


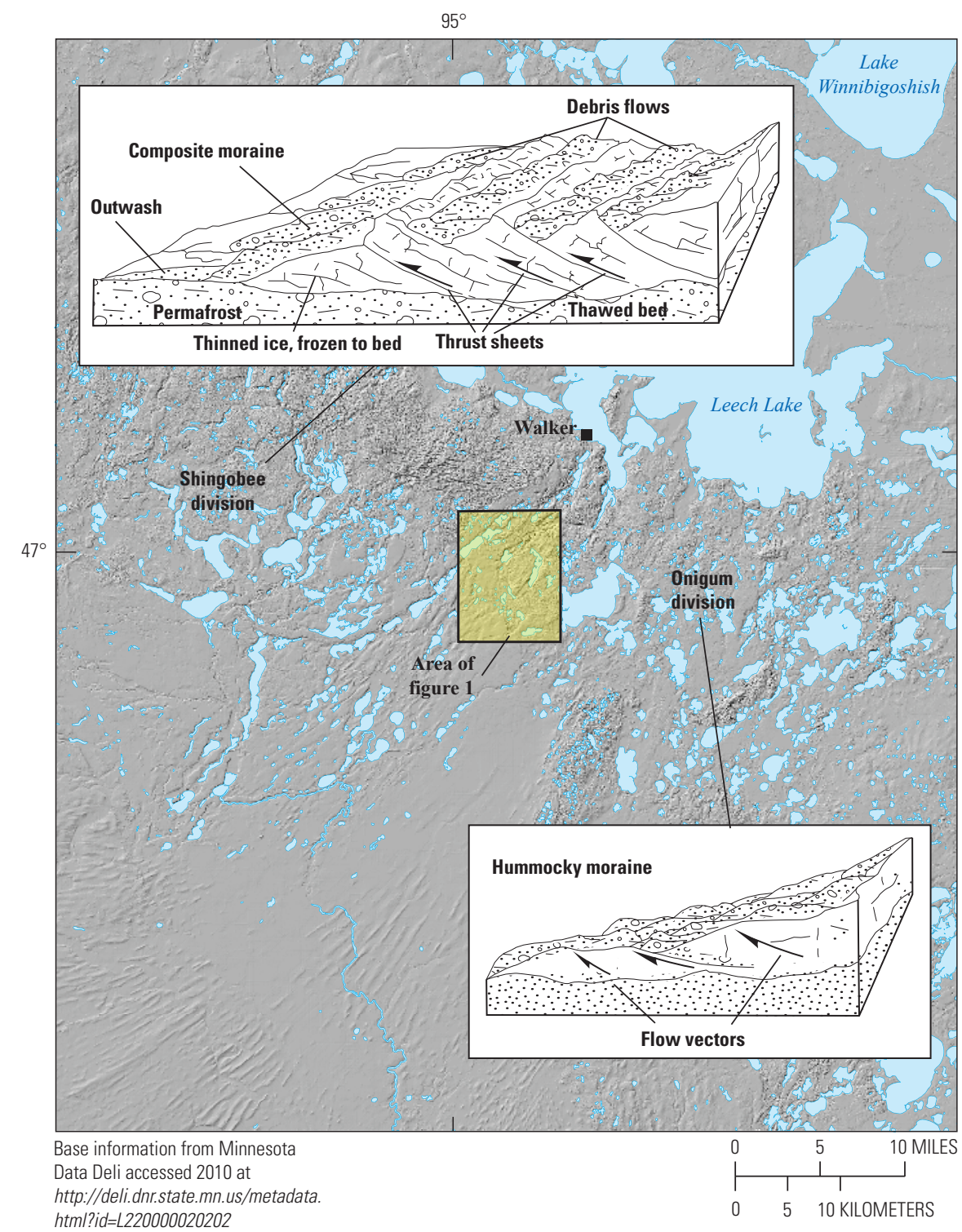

Figure 14. Two styles of till deposition within Itasca moraine in the Shingobee region, composite moraine and hummocky moraine. Source: Minnesota Department of Natural Resources (2010). 


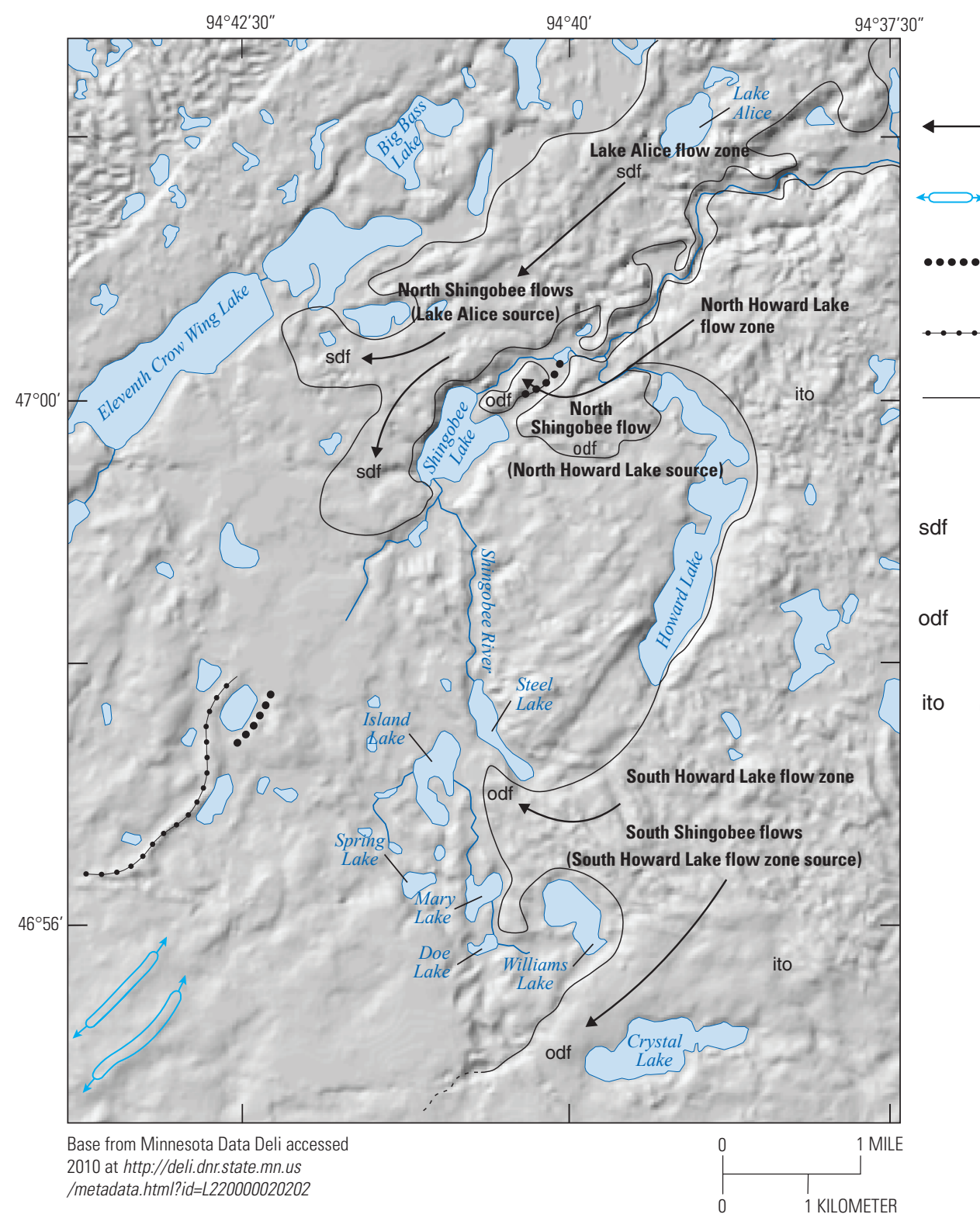

\section{EXPLANATION}

Itasca phase debris flow-Axis of general motion

Hewitt phase drumlin—Arrows along long axis

Hewitt phase boulder train-Elongated parallel to ice flow

Hewitt phase collapsed stream sedimentsRidge-like

Flow boundary—Dashed where approximate

\section{LIST OF MAP UNITS}

Itasca phase deposits

Debris flow-Proglacial run-outs originating from the Shingobee division of the Itasca moraine, younger than $14.7 \mathrm{ka}$

Debris flow-Proglacial run-outs originating from the Onigum division of the Itasca moraine, younger than $14.7 \mathrm{ka}$

Onigum division of the Itasca moraine-Highly variable sediments, mostly of debris and mudflow origin, produced on the margin of the Onigum tongue of the Wadena lobe (St. Croix phase) glacier, 22.8-14.7 ka inclusive

Figure 15. Approximate positions and extents of debris flows from three flow zones on the Itasca moraine. Howard Lake debris flow zones and Lake Alice debris-flow zone are the apparent source areas. Individual flow units (North Shingobee and South Shingobee flows) are named for the locations reached by their runouts. These flows blocked the Shingobee tunnel valley in two places and thus formed glacial lake Willobee basin. Source: Minnesota Department of Natural Resources (2010). $(\langle$, less than; $\rangle$, greater than; ka, thousand years old.) 
contributing to ice surges. The second component is marginalzone permafrost. The occurrence of permafrost is suggested by frozen-ground features along the front of the Shingobee division (figs. 1, 9; unit its). Periglacial permafrost caused marginal Shingobee ice to be frozen to the base and immobile. During surges, rapid ice flow from up-glacier repeatedly collided with the frozen toe and over-thrust the margin, forming a progressive set of parallel ridges that characterize the Shingobee moraine division (fig. 14) ("composite ridges" of Aber and others, 1989).

Parallel ridges are rare on the Onigum side where randomly placed kames (hummocky moraine (Gravenor and Kupsch, 1959; Boulton, 1972)) dominate the landscape (fig. 14). Because of contact with the contemporaneous Rainy lobe on the east and the independent Shingobee ice tongue to the west, frictional flow modification of the Onigum tongue may have influenced its terminus and resulted in gradual melt-out of a debris-mantled terminal zone (see Winters, 1961) (fig. 14). Few obvious tunnel valleys are associated with most of the Onigum moraine division to the east. This observation suggests less meltwater influence on basal ice flow than was the case for the Shingobee division. Upstream ice, thinned by ablation as it approached the margin, developed upward flow vectors and raised till to the surface where it accumulated as an ablation blanket. The till blanket became mobilized by mud and debris flows and was redeposited along the ice front. Flows moved randomly along slopes that developed with changes in the ice margin.

Despite small differences, as measured by stone counts (fig. 16), the two divisions of the Itasca moraine have very similar lithologies. The Shingobee moraine division has a slightly greater ratio of basalt to granite and a somewhat higher frequency of carbonate rock fragments whereas the Onigum division has a higher frequency of quartzite. These differences might be attributable to counting error but might also be related to a slightly different provenance of the two ice tongues. For comparison, stone counts of Hewitt phase drumlins southwest of the Shingobee map area are also shown. Carbonate rocks are nearly absent in Hewitt phase material, but miscellaneous types (rocks with less than 1 percent representation) are considerably more abundant.

Miscellaneous rock types in Hewitt phase materials suggest a source area closer to the Labradorean center (fig. 6) (Mooers and Lehr, 1997). In Itasca phase deposits, miscellaneous rock types may be derived from preexisting Hewitt or older tills (see section, Shingobee Division of the Itasca Moraine (unit its)). Miscellaneous rock types in both Itasca phase ice tongues are nearly the same, but higher carbonate counts imply a source region for Itasca phase glaciers closer to the Keewatin center (fig. 6). In a broad sense, lithology suggests a contiguous source region and similar flow paths for the two Itasca ice streams.

In both Itasca moraine divisions, contact with underlying Hewitt beds is marked by an abrupt elevation change. Local relief in the Itasca moraine divisions can be $31 \mathrm{~m}(102 \mathrm{ft})$ or more, but in Hewitt ground moraine, it rarely exceeds 15-17 m (49-56 ft). In contrast to the lower slope angles common in ground moraine and various basal tills, slope angles in terminal moraine facies (such as debris flows or faulted slabs) often approach the angle of repose.

\section{Debris Flows of the Itasca Moraine (Units sdf, odf)}

Mud and debris flows from the Itasca moraine (fig. 15) can be recognized by their lobate shape, superior stratigraphic position, and such details as bedding and sorting. A

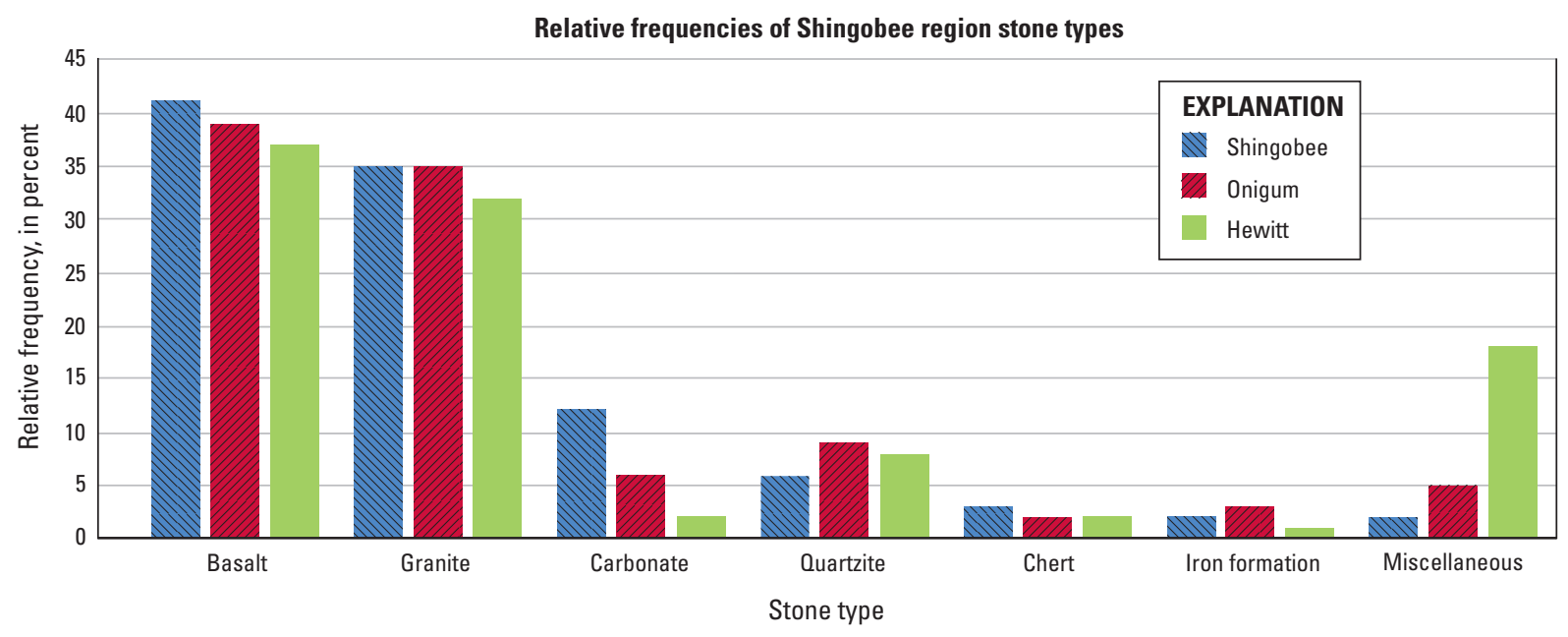

Figure 16. Relative frequency of stone types in tills in the Shingobee and Onigum divisions of the Itasca moraine compared with stone counts from Hewitt phase drumlins, Shingobee headwaters area. Miscellaneous category includes characteristic Superior lobe rock types such as red sandstone, red or purple volcanic rocks, and various gabbros, mafic gneisses, schists, and porphyritic basalts. 
relatively small subflow from the Onigum moraine division (unit odf), exposed in a road cut on along Hubbard County road 19 (a westward continuation of Cass County road 40), is typical of these map units. The road cut is approximately lat $46^{\circ} 38^{\prime} 33.2^{\prime \prime} \mathrm{N}$., long $94^{\circ} 40^{\prime} 33.2^{\prime \prime} \mathrm{W}$., about $1.5 \mathrm{~km}$ south of Crystal Lake, and parallel to the southern border of figure 1 . The deposit is part of a multiple flow with individual subflows as much as $3 \mathrm{~m}$ (10 ft) thick. The flow is similar to those described by Lawson $(1979,1981)$ as type II ("lobate, head stands above body, some shear in the lower part and in marginal zones"). Total flow thickness is about $22 \mathrm{~m}$ (72 ft). The flow has an abrupt nose that ends in the Shingobee tunnel valley at an elevation of $436 \mathrm{~m}(1,430 \mathrm{ft})$. The nose rises steeply in a series of $<5 \mathrm{~m}(<16 \mathrm{ft})$ steps, to an elevation of $458 \mathrm{~m}(1,503 \mathrm{ft})$. The top of the flow is flat (slope 1/90 or 0.01 ). Cobble and boulder concentrations, which might be due either to inverse grading or to postdepositional lagging (Lawson, 1979), lie within the vertical sequence. The Howard Lake, North Shingobee, and Lake Alice flows (fig. 15) appear to have similar morphology.

\section{Shingobee Division of the Itasca Moraine (Unit its)}

The Shingobee moraine division is a prominent feature in the north and west parts of the Shingobee region (figs. 13, 14). It is characterized by a group of parallel ridges, arranged at right angles to the presumed glacial flow axis, trending northwest-southeast (see "composite ridges" of Aber and others, 1989). Debris flows mark the approximate positions of en echelon thrust sheets (fig. 14, composite moraine inset). Hillhole pairs, deep lakes that are adjacent to down-glacier hills with a volume roughly similar to that of the lake's basin, are also common along the proximal side of the Shingobee division of the Itasca moraine (Bluemle and Clayton, 1984; Aber and others, 1989; Mooers, 1990) (fig. 5). Stones collected at or near the surface in borrow pits along roads within and near composite ridges (fig. 13), include miscellaneous rock types such as red and purple volcanics and iron formation and suggest decollement into older, subjacent tills from the Labradorean center. Decollement zone depth is estimated (from local hill-hole-pair lake depths) to be about $30 \mathrm{~m}$ (100 ft).

The combination of topographic, depositional and structural features associated with the Shingobee division of the Itasca moraine (tunnel valley networks to the north, tectonic features in the moraine, hill-hole pairs) imply wet-based ice and a periodically surging glacier that over-rode a stationary frozen toe. This condition may exist when marginal ice is in a polar or subpolar thermal mode and frozen to its base while upstream ice is in a temperate thermal regime, at or near the pressure-melting point and with abundant basal meltwater (see Benn and Evans, 1998). In many respects, the Shingobee moraine division is comparable to end moraine in North Dakota where Clayton and Moran (1974) and Moran and others (1980) proposed a frozen toe along the margin of the
Laurentide ice (see section, Speculations Regarding the Itasca Phase).

\section{Possible Permafrost Features (Unit its)}

Unusual geomorphic features lie in the northwestern corner of the Shingobee headwaters map (unit its; fig. 1). The area in question lies between the Itasca moraine (Shingobee division, fig. 13) and Hewitt ground moraine (unit hgm; figs. 1,9) along the northwest edge of the Crow Wing tunnel valley (figs. 1,8). The area can be clearly differentiated from adjacent topography as is demonstrated by the shaded relief map, figure 9 , northwest corner. The terrain is between 300 and $1,500 \mathrm{~m}$ (984 and 4,920 ft) wide and elongated parallel to the trend of the moraine, along a northeast-southwest axis for a distance of $8 \mathrm{~km}$ (about $5 \mathrm{mi}$ ). The landscape is about

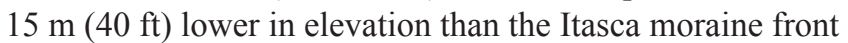
to the northwest and also lower (about 9-10 m (30-33 ft)) than Hewitt phase ground moraine (unit hgm) to the southeast.

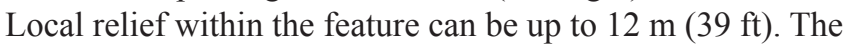
northern edge of the terrain is in contact with debris flows and thrust scarps from the Shingobee division, and its southern margin is marked by an abrupt, linear bluff, about 9-10 m (30-33 ft) high, of Hewitt phase ground moraine. Exposed sediments along road cuts within the area appear chaotically emplaced; they range from small matrix and clast-supported debris flows (less than $10 \mathrm{~m}$ (33 ft) thick) to moderately well sorted coarse and medium sands. Bedding is variable, ranging from well bedded to contorted and massive.

Topographic elements in the area are randomly placed, as opposed to preferentially oriented, such as the surface features in the Itasca moraine, Shingobee division, or in many areas of Hewitt ground moraine. Landscape elements are closer together and smaller than is typically seen in nearby parts of Hewitt ground moraine, Onigum terminal moraine, or Shingobee tunnel valley kames. A possible origin for these features may be groundwater intrusion into periglacial permafrost (see "pingos" of Bennike, 1998). This hypothesis suggests that groundwater under pressure from up-glacier heads was injected into the base of the system where it contributed to segregated ground ice (Rampton, 1988; "extrusion moraine" of Boulton and Caban, 1995). The initial topography was modified by ground-ice accumulation as permafrost became pervasive prior to and during the Itasca phase. A number of separate groundwater intrusions were probable, each derived from pressurized subglacial aquifers during surges and organized around contemporaneous, or remnant, Hewitt phase ice nuclei (see Ballantyne and Harris, 1994; Evans, 1994; Sugden and others, 1995). The lowland containing these features may have initially formed as a marginal channel along the face of the Itasca phase ice or, alternatively, by melting of intruded ice bodies along the front of the Itasca moraine at the end of the Itasca phase. Mooers and Norton (1997) mapped the area discussed above as hummocky topography in an ice-marginal setting. They note that much of the till along the front of the 
Itasca moraine (their unit Wio) had been redeposited by mass movement (flow till). A pingo setting, such as that proposed earlier, in the vicinity of Eleventh Crow Wing Lake (fig. 1), provides a hypothesis that has the advantage of accounting for the atypical geomorphic features not seen elsewhere in the region. Other areas along the front of the Itasca moraine southwest of the Shingobee area contain local lake beds, ice contact sand, gravel, and fluvial sediments (Mooers and Norton 1997).

\section{Onigum Division of the Itasca Moraine (Unit ito)}

The Onigum division of the Itasca moraine dominates the east side of the Shingobee headwaters area (figs. 1, 13, hummocky moraine of fig. 14). The Onigum division extends eastward about $40 \mathrm{~km}(25 \mathrm{mi})$ from the east edge of the Shingobee map area. Southward, the feature terminates near the town of Hackensack (fig. $2 B$ ). The west-facing side of the moraine near Shingobee is marked by large debris flows that block both the northern and southern parts of the Shingobee tunnel valley (units odf and sdf; figs. 1, 15). Ice-block depressions are numerous, some containing lakes, others dry or containing swamps or bogs. Local relief is somewhat greater than that in the Shingobee division, about $40-45 \mathrm{~m}$ (131-148 ft) compared to about 30-35 m (98-115 ft). Terrain elements are typically isodiametric and randomly arranged (hummocky moraine; Winters, 1961). The Onigum division is composed almost entirely of chaotically emplaced small hills and sandy to boulder-dominated debris flows. Minor amounts of fine-grained sand or silty material are locally present. Most exposures are notable for numerous large boulders and clast-supported pebble or cobble conglomerates. Sandy units are typically coarse grained. Bedding is usually massive and obscure but, when present, it has little lateral continuity $(<20 \mathrm{~m}(66 \mathrm{ft}))$ and poorly defined contacts.

\section{Tunnel Valleys, Ice-Block Lakes, and Terraces (Units htv1, htv2, and itt)}

Two Hewitt-age tunnel valleys, the Crow Wing (htv1) and Shingobee (htv2) tunnel valleys are found in the Shingobee area (figs. 1, 8). These valleys were only partially modified by Itasca phase activity. Both originate in the area of Walker Bay of Leech Lake (fig. 8) but diverge from one

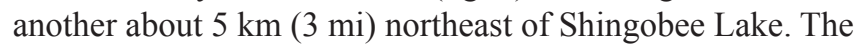
Crow Wing valley has a southwesterly axis, and the Shingobee River valley has a southeasterly axis. Depth of the valleys is about $25 \mathrm{~m}(82 \mathrm{ft})$. If one takes the depths of ice-block lakes (about $35 \mathrm{~m}$ ) (115 ft) into account, a minimum thickness of

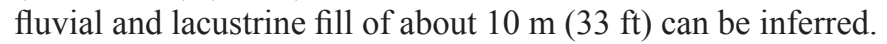
Both valleys have steep walls (slopes of about $35 / 100$ or 0.35 ) and average widths of about $1 \mathrm{~km}(0.6 \mathrm{mi})$. The Shingobee River valley ends southward because it is occluded by Hewittage kames and Itasca phase debris flows from the Onigum moraine division (units ha, odf (west of Crystal Lake); figs. 1, 15). By contrast, the Crow Wing valley proceeds southwestward from the Shingobee area uninterrupted as the Crow Wing River.

Both tunnel valleys contain a number of ice-block lakes, presumably derived from collapsed tunnel roof (unit ha; figs. 1, 11). During Hewitt phase retreat, these blocks were variously buried by debris flows and outwash. In the Shingobee area, larger ice-block lakes within the tunnel valley boundaries include Shingobee, Williams, Steel, and Island Lakes (figs. 1, 2B). In the Shingobee map area, Eleventh Crow Wing and Big Bass Lakes occupy the Crow Wing valley. Howard Lake occupies an ice-block depression in a subdivision of the Shingobee tunnel that was isolated from the main valley by Onigum division debris flows during the waning stages of the Itasca phase. Some ice-block lakes on the Onigum division of the moraine, outside the tunnel valley, are Lake Alice, Little Bass and Crystal Lakes (figs. 1, 2B). Like other ice-block lakes in the region, smaller lakes such as Mary, Spring, and Doe formed in ice-block basins when Hewitt phase ice finally melted toward the end of Itasca time. Mud and Robinson Lakes (figs. 1,2B) are shallow postglacial ponds that may be remnants of glacial lake Willobee.

In the northeastern part of the Shingobee River valley, dissected remnants of a terrace are present at elevations between 415 and $430 \mathrm{~m}$ (1,362 and 1,410 ft) (unit itt; fig. 1). The modern Shingobee River occupies a steep-walled valley that cuts through the terrace to an elevation of about $400 \mathrm{~m}$ $(1,312 \mathrm{ft})$. Sedimentation patterns in the deeply incised Shingobee River valley suggest catastrophic drainage of glacial lake Willobee as the Itasca phase came to a close (see section, End of Itasca Phase and Formation of Glacial Lake Willobee). The volume of water drained during the event is estimated to have been about 500 million cubic meters. Lake volume was approximated by using a modification of the method suggested by Welch (1948).

\section{Subsurface Geology}

In addition to 12 geological test holes, 24 hydrologic sample wells were drilled and logged in the vicinity of Shingobee, Crystal, and Williams Lakes (Winter and Rosenberry; 1997, Siegel and Winter, 1980) (fig. 12; 18 wells shown). On the basis of modal grain size, three broadly defined sedimentary facies were designated in these well logs.

- Lacustrine sediments - inferred where fine sands, very fine sands, and silts predominate in the drill cuttings. With the exception of a few thin beds of medium to coarse sand, possibly recording turbidity flows in glacial lakes, lacustrine sediments generally lack coarser particles.

- Fluvial or debris-flow facies-Assumed where the well logs described medium to coarse sand commonly accompanied by pebbles and coarser materials. 
- Till-Presumed where the well log reported it as such, or by poor sorting with pebble- to fine silt- and possibly clay-size material was evident, or it was noted by Siegel and Winter (1980).

In the vicinity of Shingobee Lake, test holes at the surface are located mostly on lacustrine sediments (fig. 12). Lacustrine units typically overlie fluvial sediments or tills. Lacustrine facies $(\mathrm{n}=7)$ in the test holes range from 7 to $45 \mathrm{~m}$ ( 23 to $148 \mathrm{ft}$ ) thick with an average of $22 \mathrm{~m}(72 \mathrm{ft})$. Close to the tunnel valley margins, the thickest lacustrine facies (intersected by drill holes T1, T5, and Mabel) tend to be underlain by fluvial or debris-flow deposits ranging from 6 to $55 \mathrm{~m}$ (20 to $180 \mathrm{ft}$ ) thick (figs. 1, 12). Thinner lacustrine deposits (holes Stenberg and T4) tend to be located farther from the tunnel valley where either till or thin fluvial or debris-flow units (1.3-3 m (4-10 ft) thick) underlie the lake deposits. Test hole Florence, located south of Shingobee Lake (fig. 12), has medium to coarse sand at the surface, which might represent a shallows, an interim shoreline, or a turbidity flow. This unit overlies a thin $(0.7 \mathrm{~m}$ $(2 \mathrm{ft}))$ lacustrine deposit.

Around Williams Lake, surface deposits include till, lacustrine sediments, and fluvial or debris-flow deposits. Lacustrine sediments in this area $(\mathrm{n}=8)$ range from about 4 to $27 \mathrm{~m}$ (13 to $89 \mathrm{ft})$ thick with an average of $10 \mathrm{~m}(33 \mathrm{ft})$. They commonly overlie fluvial or debris flow and till units. Fluvial or debris-flow materials $(\mathrm{n}=18)$ average $8 \mathrm{~m}$ (range 3-18 m) (26 ft, range 10-59 ft) in thickness. These latter sediments overlie a patchwork of till, fluvial or debris flows, and lacustrine sediments.Near Crystal Lake, either fluvial or debris-flow deposits are at the surface and no lacustrine sediments were noted in the logs. Their average $(\mathrm{n}=6)$ thickness is $3 \mathrm{~m}$ (range $<2-4 \mathrm{~m}$ ) (average $10 \mathrm{ft}$, range $7-13 \mathrm{ft}$ ). All these deposits overlie till; three well logs note boulder beds at the top of underlying tills that are interpreted as Hewitt or Hewitt-Itasca interstadial lag deposits. Well log data suggest that glacial lake Willobee was most persistent around Shingobee Lake where lake sediments are thickest. At Williams Lake, both lacustrine sediments and easily identified debris-flow units are present at the surface. The debris flow locations are consistent with a position along the edge of the lake. Glacial lake sediments are absent near Crystal Lake, where all surface sediments can be classified as debris flow or fluvial. These flows originated from the adjacent Onigum division and overlie Hewitt ground moraine.

\section{Glacial History of the Shingobee Region}

\section{Timing of Glaciation Extrapolated from Measurements in Greenland}

Glaciers are cold-climate transfer systems that receive ice and snow as mass input, then move the mass by ice flow to a warmer locality where it is released as an equal mass of liquid and vapor. This "input-transfer-output" glacier model is essentially a budget involving mass balances of water. Glacial mass-balance budgets vary with place and time and may be positive (receiving more input than is released as meltwater and water vapor), in equilibrium (mass input and output are nearly equal), or negative (loss is greater than input). These mass balance modes are climate sensitive. Positive mass balances result from greater accumulation of mass (gain of ice and snow) on a glacier surface than is lost by calving, sublimation, evaporation, and melting. Positive mass balances are associated with cold climates and increase in glacier size; they result in glacial advance. Negative mass balances are characterized by warmer conditions where ablation (output) exceeds accumulation (input). Negative budgets result in net melting and retreat of an ice-sheet terminus as the glacier diminishes in size. Equilibrium, a balanced state in which mass gain equals loss, exists when accumulation and ablation throughout the ice-sheet expanse are about equal. During equilibrium, the ice terminus is typically stationary, neither markedly retreating nor advancing, and glacier size remains constant. Large terminal moraines accumulate at the margins of a glacier that has been in equilibrium for a long period of time (see Benn and Evans, 1998).

The Greenland ice cores (Dansgaard and others, 1982; Alley and others, 1993; Taylor and others, 1993) contain a record of precisely dated temperatures that can be related to glacial behavior in the Shingobee region (fig. 17). The ice cores are dated by counting annual accumulation layers (error $<1$ percent; Alley, 2004). Oxygen isotopes in the ice capture atmospheric temperature at the time that a layer was formed.

Major temperature fluctuations in Greenland were cyclical and associated with two phenomena: Heinrich events (Heinrich, 1988; Bond and others, 1992) and DansgaardOeschger events (Bond and Lotti, 1995; Bond and others, 1999) (fig. 17).

Heinrich events are cold periods recorded by changes in foraminifera species, carbonate content, and clay mineralogy in Atlantic abyssal sediment cores. The oceanic sediments reflect disruption of North Atlantic thermohaline circulation by meltwater runoff from North America. As the ocean surface cools and its salinity declines, ice cover expands and thermohaline circulation in the North Atlantic is subdued, resulting in relative warming of the southern oceans as the northern hemisphere cools (Rahmstorf and others, 2005). Heinrich events, which are associated with radical changes in glacier behavior, typically took place near the end of a glacial phase. Six Heinrich events during the Wisconsin are documented in North Atlantic sediment cores (Bond and Lotti, 1995). These events are numbered sequentially from the most recent $(\mathrm{H} 0)$ to the oldest (H6). Events $\mathrm{H} 0, \mathrm{H} 1, \mathrm{H} 2$ and $\mathrm{H} 3$ occurred during glaciation in the Shingobee region (fig. 17).

Dansgaard-Oeschger (D-O) events (interstadials) are warm climatic fluctuations between major glacial episodes (stadials). They typically take place at the end of Heinrich events. In a D-O cycle, temperatures warm rapidly for a few decades then cool for several hundred to more than a thousand years (events D-O1, D-O2, and D-O3; fig. 17). 
GISP2 Temperatures

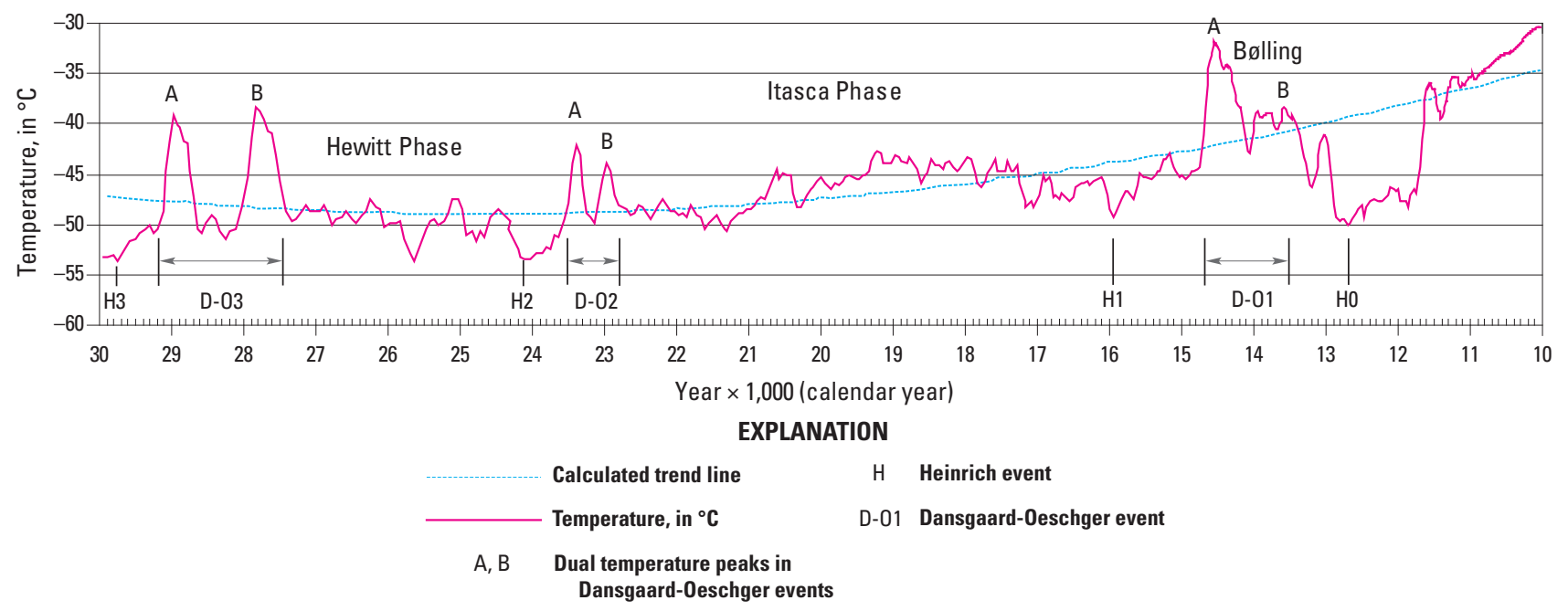

Figure 17. Summary of temperatures in Greenland during 30-10 thousand years ago as recorded in Greenland Ice Sheet Project 2 (GISP2) cores. Calculated trend line extends from early Hewitt phase (about 30 thousand years ago) to retreat of ice from Minnesota (about 10 thousand years ago). Source: Alley (2004).

Alley (2004) noted that abrupt climate changes, shown by temperatures recorded in the central Greenland ice cores (Greenland Ice Sheet Project 2 (GISP2)), were reflected in the rest of the world within 30 years. If one assumes appropriate changes in precipitation type (snow or rain) at accumulation centers inland (fig. 6), it is reasonable to suggest that mass balance changes in North American glacial systems can be related to major Greenland temperature fluctuations (fig. 17, table 1).

GISP2 data may reflect the timing of adjustments of general mass balance budgets on the Laurentide ice sheet, which in turn influences glacial behavior, but they do not provide spatial information such as position of glacial termini, flow patterns, or approximate equilibrium-line positions. These indicators of glacial activity are more commonly defined by interpretation of lithologic data such as stone counts, geomorphic studies of features like outwash, moraines, till bodies, and erosional patterns, along with paleontologic studies and stratigraphic relationships. Analysis of glacial spatial properties is often accompanied by ${ }^{14} \mathrm{C}$ (carbon-14) or other radiometric dates (for example, ${ }^{10} \mathrm{Be}$, beryllium-10). These dates have been used in a several studies to constrain limits to dates assigned to glacial activities of the western part of the Laurentide ice sheet (see Mooers and Lehr, 1997; Bettis, 1997).

For the purpose of this report, Pleistocene temperatures, suggesting positive mass balance on the Laurentide ice sheet, were inferred after a drop in temperature associated with a D-O event (Bond and Lotti, 1995; Bond and others, 1999). In a similar fashion, impending negative mass balance budgets are suggested by the onset of Heinrich events (Heinrich, 1988; Bond and others, 1992) (fig. 17). Heinrich events immediately precede a D-O cycle rise in temperature and its corresponding negative-trending mass balances. The point selected to represent onset of either positive or negative budgets was arbitrarily set at the intersection of appropriate parts of the temperature profile with a calculated trend line that was determined by using the least squares method (fig. 17). The intersections of the trend line and the temperature profile in the vicinity of Heinrich and D-O events identify the dates shown in table 1. Dates are in calendar years based on counts of annual accumulation as indicated by GISP2 data (Meese and others, 1994; Alley, 2004).

In the current report, ${ }^{14} \mathrm{C}$ dates are noted as "BP," meaning "before present," arbitrarily set at 1950. Dates labeled BP in the literature commonly imply the assumptions that atmospheric radiocarbon level has always been the same as it was in 1950 and that the half life of ${ }^{14} \mathrm{C}$ is 5,568 years. ${ }^{14} \mathrm{C}$ dates can be, and often are, compared with one another as long as all participants have agreed to the assumptions noted above. It has been amply demonstrated, however, that ${ }^{14} \mathrm{C}$ levels have varied with time. Because of this variation, correction factors are required to bring ${ }^{14} \mathrm{C}$ dates into a degree of concordance with actual calendar years. By obtaining radiocarbon signatures from samples of known calendar age, tree rings for example, a calibration curve (Reimer and others, 2004) extending back 26,000 years has been developed that calibrates ${ }^{14} \mathrm{C}$ dates to allow their direct comparison to calendar years. For example, $21,341{ }^{14} \mathrm{C} \mathrm{BP}$ is comparable to 26,000 calendar years.

Calendar years, as determined from the Greenland annual accumulation counts, are identified by the suffix "cal." Calibrated BP dates using the 2004 correction curve, or calculations based on it (Danzeglocke, 2011), are marked with an asterisk (cal*)

When used to date glaciation, ${ }^{14} \mathrm{C}$ data have the disadvantage that they are almost always derived from biological materials that originally formed in places where ice wasn't present. On occasion, biological material might be 
incorporated into tills after their place of origin had been overrun by glacial ice, but its connection with the glacier is, by necessity, indirect and usually requires stratigraphic interpretation to establish relevance (for example, wood incorporated into Hewitt-age tills; Mooers and Lehr (1997).

Dates based on calendar-year counts present a different set of problems, the most important of which is a lack of spatial connection. Calendar dates based on annual-layer counts from Greenland need to be supplemented by local field observations before being applied with confidence. Other sources of uncertainty in Greenland data lie with interpretation of the temperature curve. For example, there are two prominent high temperature peaks during D-O3 at $27.8 \mathrm{ka}$ and $29 \mathrm{ka}$ (fig. 17, Hewitt peaks A and B) separated by a short period (about 0.8 thousand years (k.y.) of positive net balance. This phenomenon makes timing of onset of the Hewitt phase problematic, at least with respect to this report's definition of onset, which is the downslope of the peak that leads to prolonged cold temperatures (for example, Hewitt peak B) (fig. 17) where it intersects the trend line. The same double-peak shape, with a relatively brief period of net positive balance between them, is seen at the beginning of the Itasca phase (D-O2) and, to a lesser extent, at D-O1 as well. Although the following comment is speculative, I suggest that brief periods of positive net balance between peaks A and B may have stabilized ice retreat, and that temperature increase indicated by the second peak may have accompanied increased precipitation over the ice sheet which hastened its subsequent advance.

\section{Carbon-14 Dates-Hewitt Phase}

Mooers and Lehr (1997) noted eight ${ }^{14} \mathrm{C}$ dates based on wood from Hewitt phase deposits along with a number of other ${ }^{14} \mathrm{C}$ dates having stratigraphic equivalence. All these ${ }^{14} \mathrm{C}$ dates are in excess of 30,000 yr BP $\left(34,089 \pm 178 \mathrm{ka} \mathrm{cal}^{*}\right.$, rounded to $34.1 \mathrm{ka} \mathrm{cal*}$ ). Mooers and Lehr (1997) suggest that the wood samples recovered from Hewitt till represent a preHewitt, mid-Wisconsin forest that was overrun and reworked. Although the Hewitt till wood ${ }^{14} \mathrm{C}$ dates are few in number $(n=8)$ and quite variable, they nevertheless indicate that the local arrival of Hewitt glaciation was subsequent to about 30,000 yr BP.

Mooers and Lehr also noted that the onset of the Hewitt phase is additionally constrained by stratigraphic association. They point out that the date for a Des Moines lobe till (in the sense of originating from the Keewatin region), in the upper part of the Sheldon Creek Formation in Iowa and stratigraphically underlying Hewitt phase deposits (Bettis, 1997), is $26,000 \mathrm{yr} \mathrm{BP}\left({ }^{14} \mathrm{C}\right)$. The calibrated Sheldon Creek Formation date (Danzeglocke, 2011), is $30,967 \pm 357 \mathrm{ka} \mathrm{cal}^{*}$ (rounded to $31 \mathrm{ka} \mathrm{cal} *$ ).

Table 1, showing calendar years based on Greenland ice core accumulation-layer counts, suggests an increase of Hewitt phase positive mass balance at $27.2 \mathrm{ka} \mathrm{cal}$. This date was arbitrarily chosen after the second of two abrupt temperature peaks during D-O3 (Hewitt peak B, fig. 17), because this point is situated at the beginning of protracted low temperatures that characterize the rest of the Hewitt phase. Discrepancies between the Sheldon Creek Formation date and the ${ }^{14} \mathrm{C}$ wood dates, compared with the date determined from figure 17, are 3.6 k.y. cal* (Sheldon Creek Formation) and 6.7 k.y. cal* (wood dates) respectively. The 3.6 k.y. time frame involving the Sheldon Creek Formation date is much closer to the $27.2 \mathrm{ka}$ cal onset date suggested by the Greenland data and closer still (about 2.4 k.y.) to the $28.6 \mathrm{ka}$ cal date at the base of the first large temperature drop (Hewitt peak A, fig. 17) of the temperature peak pair seen during D-O3 (fig. 17). The Sheldon Creek Formation date depends on retreat of the Des MoinesRed River lobe from north-central Iowa, followed by subaerial exposure sufficient to accumulate biological carbon to support a ${ }^{14} \mathrm{C}$ analysis. This ice-free interval has little actual relationship with the Hewitt phase but it does serve to constrain the maximum time of the onset of Hewitt phase glaciation and its subsequent equilibrium on the Alexandria moraine. The wood dates clustered around 30,000 yr BP $\left(34,368 \pm 178 \mathrm{ka} \mathrm{cal}^{*}\right)$ noted above appear to be too old to adequately constrain onset of the Hewitt phase at $27.2 \mathrm{ka}$ cal.

Mooers and Lehr (1997) propose that the Hewitt phase culminated between about 23 and $21 \mathrm{ka} \mathrm{BP}$ (extrapolated from radiocarbon dates). The earlier date $(23,000 \mathrm{yr} \mathrm{BP})$ calibrates to $27,552 \pm 452 \mathrm{ka} \mathrm{cal}^{*}$ (rounded to $27.6 \mathrm{ka} \mathrm{cal}$ ) and the younger (21 ka) to $25,151 \pm 424 \mathrm{ka} \mathrm{cal}^{*}$ (rounded to $25.2 \mathrm{ka}$ $\left.\mathrm{cal}^{*}\right)$. Taking into account error ranges, both Mooers and Lehr dates can be considered to be within the range of Hewitt dates shown on table 1 ( $27.2 \mathrm{ka} \mathrm{cal}^{*}$ to $\left.23.6 \mathrm{ka} \mathrm{cal}^{*}\right)$. The younger date $\left(25.2 \mathrm{ka} \mathrm{cal}^{*}\right)$ is close to a sharp dip in temperature below the trend line near the middle of the Hewitt phase (fig. 17) and the older $\left(27.6 \mathrm{cal}^{*}\right)$ to the sharp drop in temperature associated with the end of D-O3, near the beginning of the Hewitt phase. Additional ${ }^{14} \mathrm{C}$ dates applicable to the Hewitt phase are rare in the literature (see Gajewski and others, 2011).

\section{Carbon-14 Dates_-Itasca Phase}

With the retreat of the Hewitt glacier subsequent to $\mathrm{H} 2$ (23.6 ka cal) (fig. 17), a short interstade lasting about around 800 calendar years (fig. 17, table 1) preceded the advance of the Itasca lobe. Data shown in figure 17 and table 1 suggest that the Itasca lobe had a positive mass balance beginning around $22.8 \mathrm{ka}$ cal and that, discounting surges, the glacier remained more or less in equilibrium on its terminal moraine until around $14.7 \mathrm{ka}$ cal, an interval of around 8.1 k.y. cal.

Because of the absence of ${ }^{14} \mathrm{C}$ dates directly attributable to the Itasca phase, radiocarbon-dated activities associated with the adjacent, more or less contemporary, Rainy lobe (St. Croix phase), were referred to by Mooers and Lehr (1997) as representative of regional ice behavior. Birks (1976) reported a series of ${ }^{14} \mathrm{C}$ dates from an area near Wolf Creek, about $96 \mathrm{~km}$ (60 mi) south of Shingobee Lake and a few kilometers inside the St. Croix terminal moraine. These dates relate to retreat 
of the Rainy lobe northward past Wolf Creek about $15.1 \mathrm{ka}$ $\left(18,500 \mathrm{yr} \mathrm{cal}^{*}\right)$. The Rainy lobe date is older $(3,800 \mathrm{yr}$ cal $)$ than the $14,700 \mathrm{yr}$ date proposed here. If geographic separation and differences in ice flow between the Rainy lobe and the Itasca lobe (see Lusardi and others, 2011, Adams and others, 2011) are taken into account however, the two dates relating to ice retreat may become somewhat more congruent.

Mooers and Lehr (1997) propose Itasca phase culmination dates between 16,000 and $15,500 \mathrm{yr} \mathrm{BP}\left(19,160 \mathrm{yr}^{\mathrm{cal}}{ }^{*}\right.$ and $\left.18,800 \mathrm{yr} \mathrm{cal}^{*}\right)$ and a date of $15,000 \mathrm{yr} \mathrm{BP}(18,600 \mathrm{yr}$ $\mathrm{cal}^{*}$ ) for the beginning of ice retreat. I propose that conditions favorable for Itasca phase glaciation began about 22,800 yr cal and ended about 14,700 yr cal (fig. 17, table 1). Data in figure 17 suggest that the Itasca phase was coldest about $21,300 \mathrm{yr}$ cal with a slightly warmer point at H1 (about $16,000 \mathrm{yr}$ cal). Culmination dates around 16,000-15,500 yr BP (17,200 yr cal* to $16,700 \mathrm{yr} \mathrm{cal}^{*}$ ), proposed by Mooers and Lehr (1997), fall between the calendar year dates derived from the Greenland cores.

Quaternary geology in the vicinity of Shingobee Lake reflects direct and indirect effects of glaciation that took place for about 17,600 years between about 29,200 and 11,600 yr cal (fig. 17, table 1). During this time, the climate was mostly glacial but was punctuated by prominent warm periods (interstadials) associated with glacial recession. Speculations and some general conclusions regarding glacial activities between the beginning of the Hewitt phase and the end of the Itasca phase are presented in the following sections.

\section{Speculations Regarding the Hewitt Phase}

Extensive tunnel valley networks that developed early in the Hewitt phase (possibly initiated near Hewitt peak B, about $27.8 \mathrm{ka}$ ) (fig. 17) and the exceptionally sandy nature of substantial parts of ground moraine in the Shingobee area suggest that basal Hewitt ice was wet and at or near the pressure melting point. Additional evidence of subglacial meltwater includes tunnel valleys whose detailed sedimentology indicates variable discharge and whose total thickness of fluvial sediments often exceeds $10 \mathrm{~m}(30 \mathrm{ft})$. On the ground surface outside the tunnel valleys, a streamlined topographic fabric was molded by plastic deformation of saturated substrate (Patterson and Hooke, 1995). Pore water, extruded from the sediment by overburden pressure, contributed to subglacial drainage and may have removed fines in the process (Nye, 1973). Water flow at the ice base helped to produce boulder and cobble lags along the flanks of streamline forms by sheet erosion and also contributed to flow in the tunnel valleys. During periods of low stream discharge and reduced hydrostatic heads, basal ice flow in the tunnels maintained the linear courses of suitably oriented valleys while simultaneously redepositing sandy melt-out tills and sparse fluvial and lacustrine materials within them.
Clark (1993) concluded that large-scale Canadian lineations such as megaflutes, similar in origin to elongate drumlins southwest of the Shingobee region (fig. $5 B$ ), were a product of rapid ice flow. Clark calculated that ice flow rates of 400 $1,600 \mathrm{~m}(1,312-5,248 \mathrm{ft})$ per year were required to form them. Local Hewitt phase flow rates, at least during surges (possibly associated with small temperature peaks around 27.5 to $27.2 \mathrm{ka}, 26.5 \mathrm{ka}, 26.2 \mathrm{ka}, 25.8 \mathrm{ka}$, and $24.7 \mathrm{ka}$ ) (fig. 17) were probably similar. Toward the end of episodic surging and drumlin formation (about $23.6 \mathrm{ka}, \mathrm{D}-\mathrm{O} 2$, fig. 17), the budget of the Hewitt ice sheet became negative. The equilibrium terminus of actively flowing Hewitt ice retreated northward, and remnant ice in the Shingobee region thinned and became inactive. Summer melting produced supraglacial stream networks that deposited outwash throughout the stagnant ice zone. Some of the ice-contact stratified drift was deposited in an ice-walled basin in the southwestern part of the Shingobee map area (unit ho, fig. 1). Less than about $5 \mathrm{~km}(3 \mathrm{mi})$ south of the Shingobee map area, this outwash pinches out or is covered by younger deposits associated with the much larger Park Rapids sand plain to the southwest (fig. 5B).

As Hewitt ice disappeared (around $23.6 \mathrm{ka}$ ), hydrostatic head was permanently reduced in the tunnel valley systems and active ice flow in the tunnel depressions ceased. Without hydrostatic or basal ice support, ice blocks from tunnel roofs collapsed into subglacial valleys. Ice blocks were partially or completely buried by outwash and debris flow. During the interstade between the end of the Hewitt phase and the advance of the Itasca lobe, Hewitt phase tunnel valley channels may have also contained drainage from active ice further to the north, at least during the summer ablation season (fig. 8).

\section{Speculations Regarding the Hewitt-Itasca Interstade}

During the Hewitt-Itasca interstade (D-O2, duration about 800 years), and possibly well into the Itasca phase, some Hewitt ice blocks appear to have remained intact. This conclusion is based on the pattern of debris-flow emplacement along the front of the Itasca phase, Onigum moraine division. Debris flows appear to have been diverted around both the northern and southern ends of an obstructing ice block occupying the Howard Lake basin (figs. 1, 15). Rampton (1988) and French and Harry (1990) noted that buried ice can persist for thousands of years. It seems likely that some of the tunnel-roof blocks in the Shingobee region remained intact at least until the formation of glacial lake Willobee near the end of the Itasca phase.

During the interstade between the Hewitt and Itasca phases, active Hewitt ice retreated northward. The local equivalent (unit hgm) of the Marcoux Formation (figs. 1, 7B) was exposed; it consists mostly of sandy subglacial deposits, fluvial components, and ground moraine. West and northwest of the Shingobee region, overlying clays of the 
St. Hilaire Formation (not present in the Shingobee map area; fig. $7 \mathrm{~B}$ ) were deposited in proglacial lakes along the front of the retreating Hewitt ice. The sedimentary couplet consisting of Hewitt ground moraine facies (Marcoux Formation) and proglacial lake beds (St. Hilaire Formation) (Crow Wing River and Goose River Groups, fig. 7B) is found in wells throughout north-central Minnesota (Minnesota Geological Survey and Minnesota Department of Health, 2010).

\section{Speculations Regarding the Itasca Phase}

Rapidly falling temperatures during the post-Hewitt warm period (D-O2) reached the calculated trend line (fig. 17) about $22.7 \mathrm{ka}, 300$ years after the second of two warm peaks at D-O2 (peak B, fig. 17). This point was arbitrarily chosen to represent the approximate onset of a positive budget in Itasca phase ice. It is not known from this datum how long it took the Itasca phase to reach and attain equilibrium on the Itasca moraine, but arrival of the ice front at Shingobee within a thousand years or so after the onset of positive mass balance seems reasonable. The inferred arrival time $(21.7 \mathrm{ka})$ is near the coldest point of the early Itasca phase, about $21.4 \mathrm{ka}$ (fig. 17). The Wadena lobe remained on or near the Itasca terminus for about 7 k.y., until the end of $\mathrm{H} 1$ and just prior to Bølling warming (D-O1) (for example, see Deschamps and others, 2012). During Itasca time, Greenland ice cores show temperature fluctuation of about 2 to $6^{\circ} \mathrm{C}$ with an average frequency of about 1.4 k.y. (range, 1.8 to $1.1 \mathrm{k} . \mathrm{y} ., \mathrm{n}=5$ ). The data are based on low temperatures at $21.4 \mathrm{ka}, 20.3 \mathrm{ka}, 18.7 \mathrm{ka}$, $17.2 \mathrm{ka}$, and $15.9 \mathrm{ka}$, and their subsequent rise to adjacent high points (fig. 17). Variations of this magnitude could be expected to have had some influence on Itasca phase ice-flow dynamics and may have contributed to subglacial drainage, multiple surges, and compressional events on the moraine.

At its southern extent, the Itasca phase glacier consisted of eastern (Onigum) and western (Shingobee) ice tongues that were, at least toward their distal portions, independent of one another (fig. 13). The difference in flow behavior of the two ice streams and their markedly different terminal moraines may reflect weather components in the ice accumulation zones such as storm tracks and frequency, or other factors such as patterns of subglacial drainage, subglacial topography, contact with other ice masses, and flow volumes. During much of the Itasca phase, the Shingobee and Onigum ice streams were in contact along a north-south line roughly coincident with the axis of Onigum Point of Leech Lake (fig. 13). Where this suture intersected the ice margin, an erosional gap, associated with subglacial tunnel drainage along the ice front, developed. The gap is about $6.5 \mathrm{~km}$ (4.0 mi) wide and floored by stream sediments partially covered by debris flows from adjacent parts of the Itasca moraine (fig. 18). As the Itasca phase progressed, subglacial meltwater from several tunnel valleys converged within this area, about $8 \mathrm{~km}(5 \mathrm{mi})$ northeast of Shingobee Lake and roughly coincident with modern Walker
Bay (fig. 8). Streams flowed southward from the confluence and through the erosional gap in the moraine before diverging into the Crow Wing and Shingobee tunnel valleys near what is now the southern end of Walker Bay. A floodplain remnant of this system can be identified in the Shingobee River valley as a paired terrace between 415 and $430 \mathrm{~m}(1,361$ and 1,410 ft) (unit itt; figs. 1, 9, 19). The terraces are dissected and partially covered by debris flows from the Onigum division of the Itasca moraine to the north and northeast. The gradient of these terraces is about 6.6 meters per kilometer $(\mathrm{m} / \mathrm{km})$ (about 38 feet per mile (ft/mi)) toward the southwest, reflecting flow direction during Itasca time (fig. 19). The modern Shingobee River gradient is in the opposite direction, downstream toward Leech Lake, at around $4.6 \mathrm{~m} / \mathrm{km}(24 \mathrm{ft} / \mathrm{mi})$.

Toward the end of Itasca phase ice activity (about 16$15 \mathrm{ka}$ ), early stages of glacial lake Willobee (see section, End of Itasca Phase and Formation of Glacial Lake Willobee) may already have been underway, because the southern part of the Shingobee tunnel valley had already become blocked by debris flows from the South Howard Lake flow zone (north and east of Crystal Lake) (fig. 15). Crow Wing drainage, however, appears to have remained active. Solifluction and debris flow from the Shingobee division of the Itasca moraine into the Crow Wing tunnel valley may have contributed to segmentation of the Crow Wing valley into separate lake basins about this time (16-15 ka).

In the Shingobee division of the Itasca moraine, surge behavior is demonstrated by geomorphic features such as sets of composite ridges, hill-hole pairs (fig. 5B), and several large debris flows (figs. 13, 15). Of particular significance in the history of the Shingobee headwaters area is a large hill-hole pair in which a rigid, frozen block of moraine and tunnel valley sediments, known locally as Ah-Gwah-Ching, was moved from an area north of Walker Bay of Leech Lake (figs. 20, 21) into the Shingobee area.

Ah-Gwah-Ching was originally part of the Itasca moraine located in the area between Walker Bay and Steamboat Bay (fig. 20, location 1). During the final surge events of the Shingobee ice tongue, beginning around $16 \mathrm{ka}$, overpressured groundwater that had accumulated in the terminal zone beneath the frozen surface reduced grain-to-grain contact in the tills under the terminal moraine (fig. 21). Lateral stress imposed by surging ice along the till-block's surface slid Ah-Gwah-Ching over this slurry, through the moraine gap at the ShingobeeOnigum suture line (fig. 18A; fig. 20, location 2), and finally into the Shingobee tunnel valley (fig. 20, location 3).

At Walker, the tunnel-valley-terrace surface beneath Ah-Gwah-Ching has an elevation of about $387 \mathrm{~m}(1,269 \mathrm{ft})$. The block surface has an elevation of a little over $460 \mathrm{~m}$ $(1,508 \mathrm{ft})$. The block is about $73 \mathrm{~m}(239 \mathrm{ft})$ thick, and its lateral dimensions are about $3 \times 8 \mathrm{~km}(1.9 \times 5$ miles $)$. This volume, although large, about $1.752 \mathrm{~km}^{3}\left(0.42 \mathrm{mi}^{3}\right)$, is comparable to that of some other hill-hole systems associated with the Laurentide margin (Bluemle, 1991) 


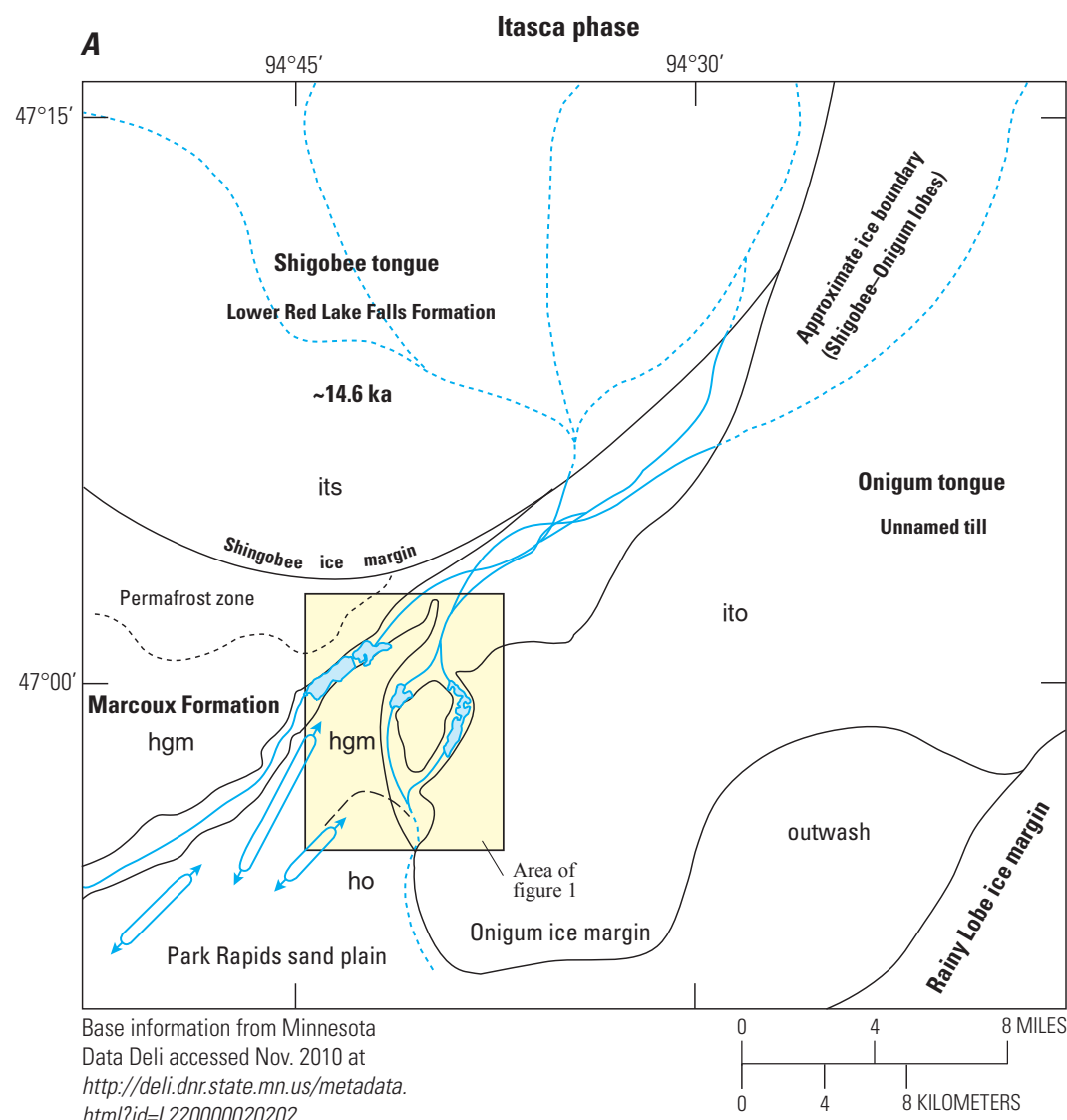

\section{LIST OF MAP UNITS}

Itasca phase deposits

its Shingobee division of the Itasca moraine-Highly variable sediments, mostly derived from debris mudflows produced on the margin of the Shingobee tongue of the Itasca phase glacie , 22.8-14.7 ka inclusive

ito Onigum division of the Itasca moraine - Highly variable sediments, mostly of debris and mudflow origin, produced on the margin of the Onigum tongue of the Itasca phase glacier, 22.8-14.7 ka inclusive

\section{Hewitt phase deposits}

ho Hewitt phase outwash-Well sorted sands and gravels deposited at the end of the Hewitt glaciation, about $23.5 \mathrm{ka}$

hgm Hewitt ground moraine-Sands and a few silts deposited at the base of the Hewitt phase glacier, characteristically sandy with intercalated gravel beds, older than $23.6 \mathrm{ka}$

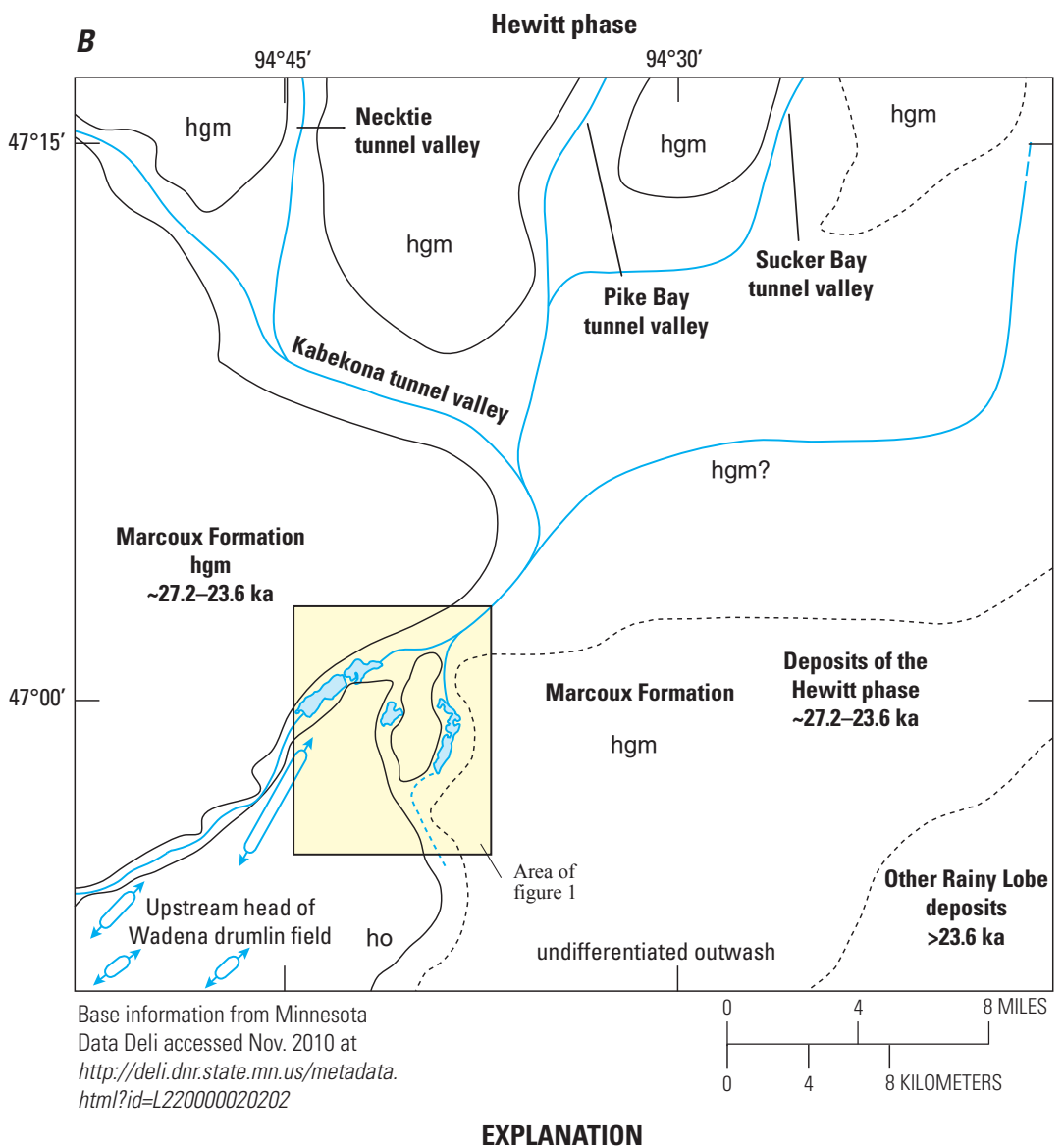

EXPLANATION

Limit of labeled unit-Solid where approximate, dashed where uncertain

Drumlin—Arrows along long axis

Figure 18. $A$, The Shingobee region at the end of the Itasca phase (about $14.7 \mathrm{ka}$ ), just prior to the Shingobee ice tongue surge that moved the Ah-Gwah-Ching block into the marginal part of the Itasca phase subglacial drainage system at the Shingobee-Onigum suture zone. $B$, The same during the Hewitt-Itasca phase interstade (23.6-22.8 ka). 


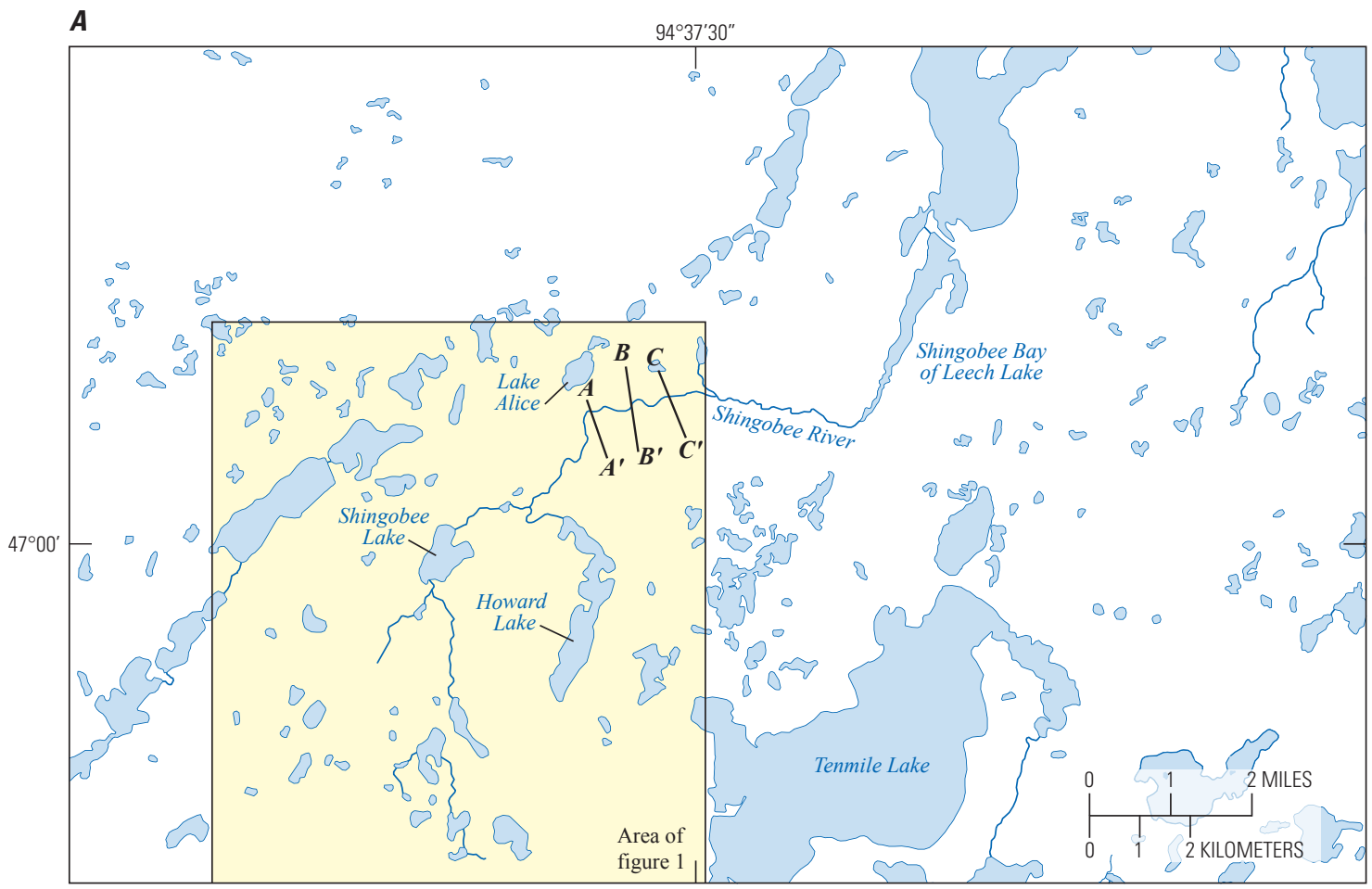

Base information from Minnesota

Data Deli accessed Nov. 2010 at

http://deli.dnr.state.mn.us/metadata. html?id=L220000020202

$B$
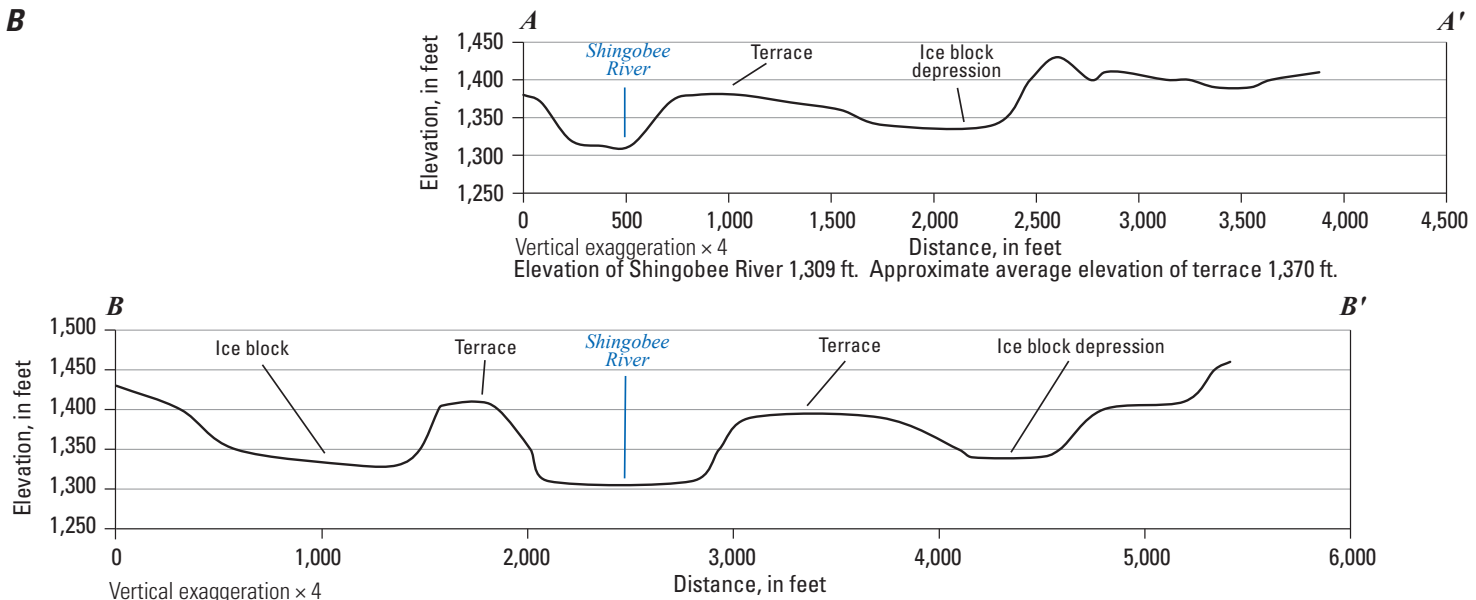

Elevation of Shingobee River 1,306 ft. Approximate average elevation of terrace 1,390 ft. Ice block depressions occur on terrace surface.

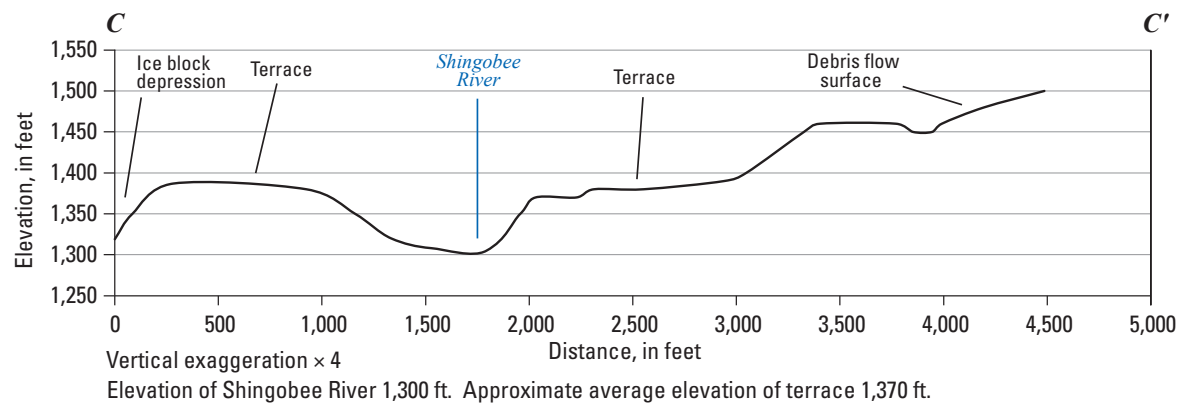

Figure 19. Terraces in Shingobee River headwaters area. $A$, Lines of cross section. $B$, Terrace remnants were floodplains in the Hewitt phase Shingobee tunnel valley. The terraces were later dissected and obscured by debris flow from the Onigum division of the Itasca moraine (Itasca phase) to the north and northeast. Location of cross sections below. lat, latitude; long, longitude. A- $\mathrm{A}^{\prime}: \mathrm{A}=1$ lat $47^{\circ} 02^{\prime} 23^{\prime \prime} \mathrm{N}$.,

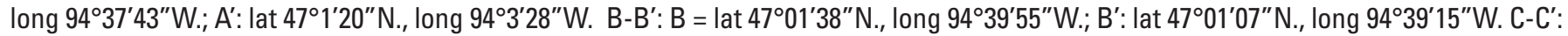

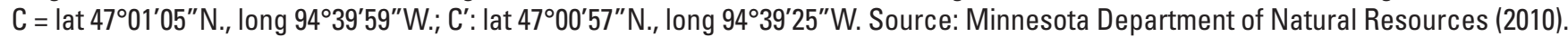




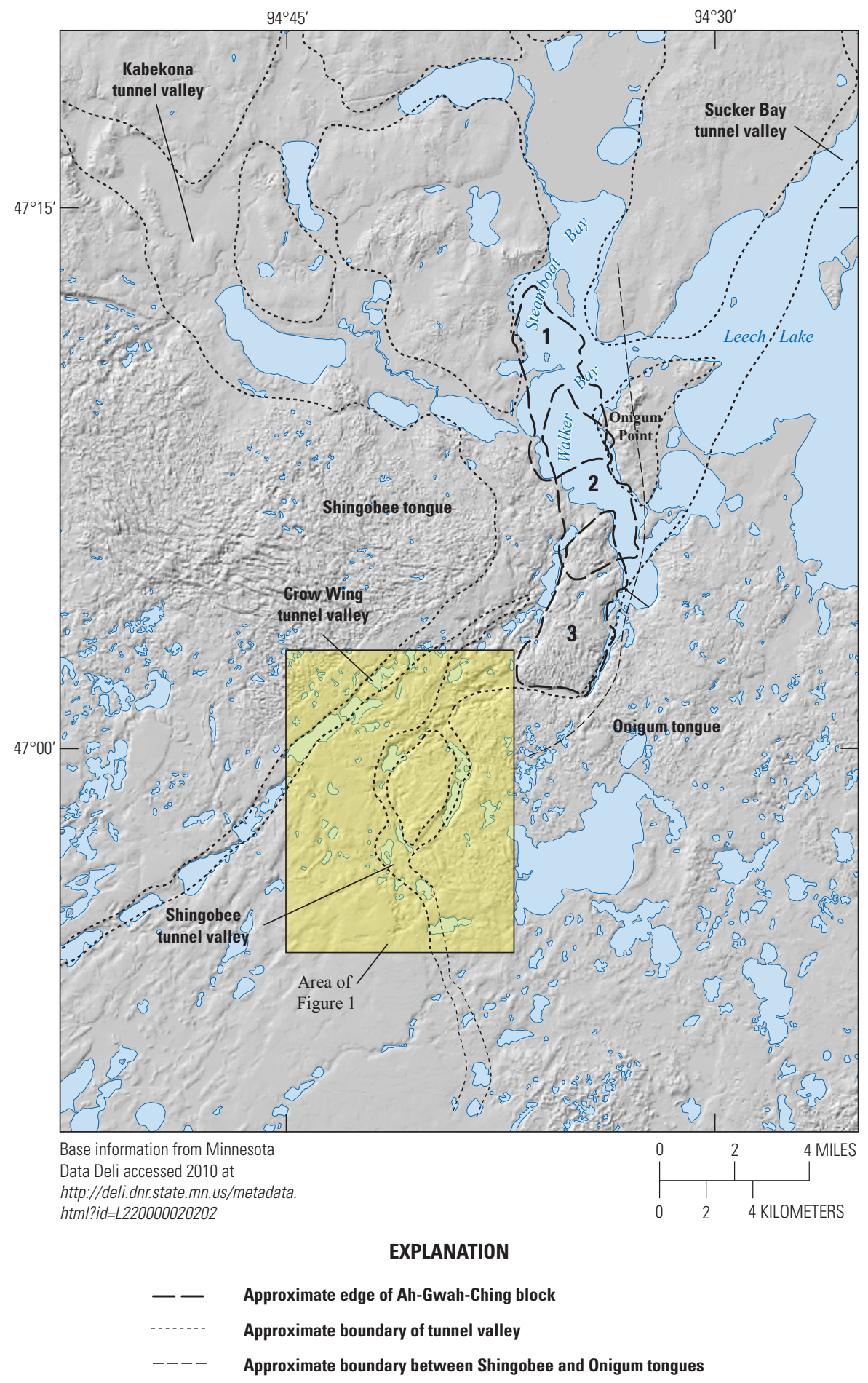

Figure 20. Successive positions $(1,2,3)$ leading to the emplacement of the Ah-Gwah-Ching hill-hole pair in the Shingobee-Onigum suture zone and major tunnel valleys at the end of the Itasca phase in the Shingobee region. Map source: Minnesota Department of Natural Resources (2010). 

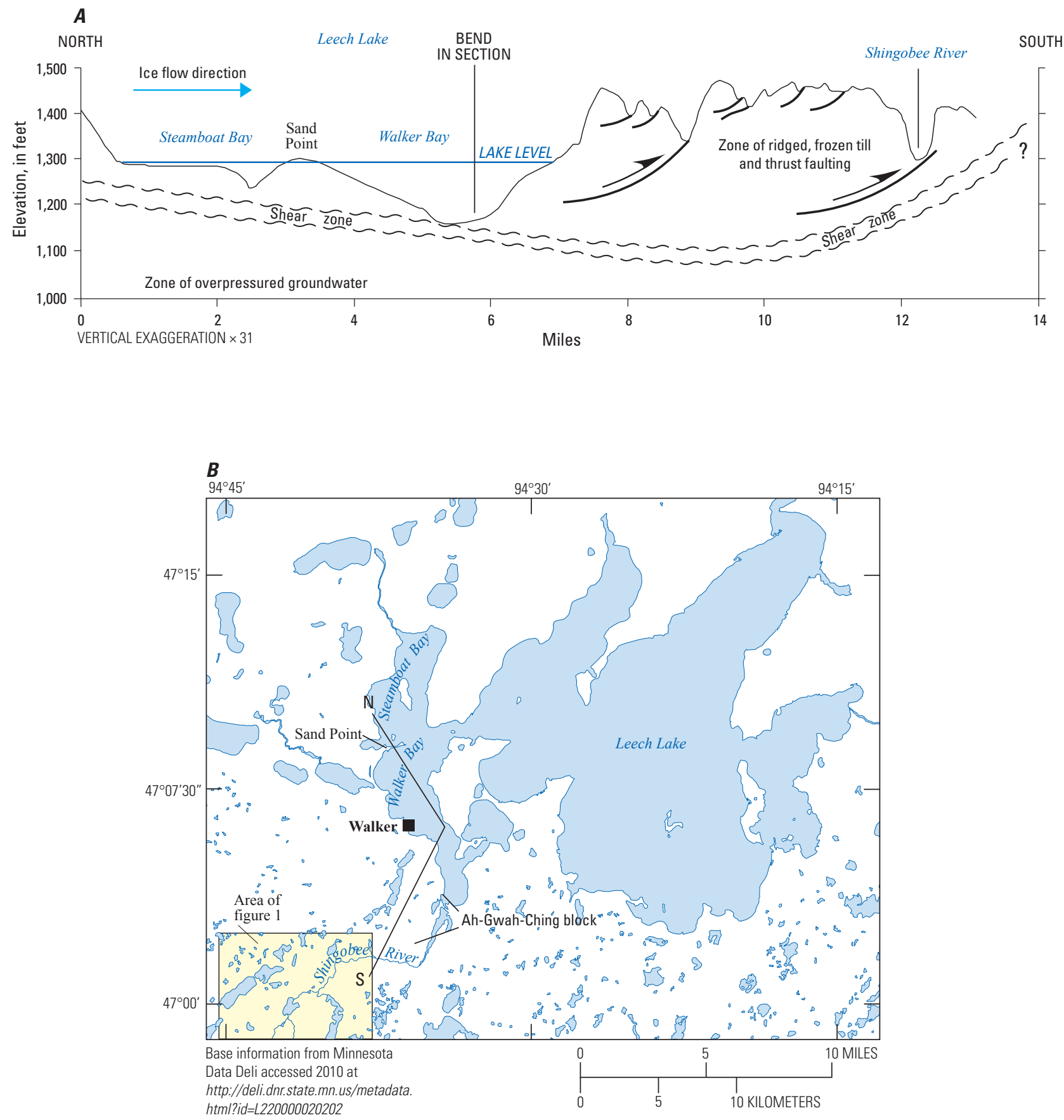

Figure 21. Possible physical parameters important in the emplacement of Ah-Gwah-Ching block. A, Longitudinal section across Walker and Steamboat Bays. $B$, Line of cross section. Additional hill-hole pairs are noted northwest of Ah-Gwah-Ching (fig. 5B). Source: Minnesota Department of Natural Resources (2010). 


\section{End of Itasca Phase and Formation of Glacial Lake Willobee (16-14.7 ka)}

In association with the cold period at $\mathrm{H} 1$ around $16 \mathrm{ka}$ (fig. 17), glacial lake Willobee began to form and drainage patterns changed in the Shingobee tunnel valley. Prior to H1, subglacial streams drained south to southwest in both the Crow Wing and Shingobee tunnel valleys. Near and subsequent to H1, however, the Shingobee tunnel valley was flooded by accumulating meltwater and formed glacial lake Willobee (fig. 12).

In addition to glacial lake Willobee, it appears that rising temperatures, just after H1 (about 16 to14.7 ka, fig. 17) contributed to a variety of glaciotectonic activities in the Shingobee region, including debris flows and hill-hole pairs such as Ah-Gwah-Ching and others (fig. 5B). To account for this activity, it is proposed that exceptionally cold temperatures, about $16 \mathrm{ka}$ at H1 (fig. 17) encouraged glacial margins to freeze to their beds causing upstream ice to over-ride the margin, elevate debris to positions favoring debris flows, and produce hill-hole pairs along the proximal face of the moraine. Glacial Lake Willobee is the result of several large debris flows from the Onigum part of the Itasca moraine (figs. 1, 15) that blocked the north and south ends of the Shingobee tunnel valley, producing a large lake with an outlet through the abandoned Shingobee tunnel valley to the northeast.

Debris flows originate from three principal sources in the Shingobee headwaters area: the Lake Alice and the North and South Howard Lake flow zones (figs. 1, 15). Two of these flow sources, the North and the South Howard Lake zones, produced flows that blocked the northern and southern ends of the Howard Lake branch of the Shingobee tunnel valley, isolating this feature from the rest of the system (fig. 15). The North Howard Lake and Lake Alice flow zones also produced flows that blocked the Shingobee tunnel valley north of Shingobee Lake (fig. 15), while more or less contemporaneous flows from the south Howard Lake flow zone near Williams and Crystal Lakes (figs. 1, 9, 15) produced debris dams that filled the Shingobee tunnel valley to the south. These debris flows have elevations ranging from $446 \mathrm{~m}(1,463 \mathrm{ft})$ in the south to about $433 \mathrm{~m}(1,420 \mathrm{ft})$ in the north near Shingobee Lake. The valley segment extending from Shingobee Lake to the area south of Williams Lake was flooded to become glacial lake Willobee (Schwalb and Dean, 2002). At its maximum, glacial lake Willobee's depth was about $18 \mathrm{~m}(60 \mathrm{ft})$ in the Williams Lake Basin and $34 \mathrm{~m} \mathrm{(112} \mathrm{ft)} \mathrm{at} \mathrm{Shingobee} \mathrm{Lake.} \mathrm{Varve} \mathrm{counts}$ near Shingobee Lake suggest that glacial Lake Willobee received sediment for around 1,700 varve years between about $16 \mathrm{ka}$ and about 14.7 to $14.4 \mathrm{ka}$. During its high stand (around $16 \mathrm{ka}$ ) glacial Lake Willobee developed two outlets, about $0.7 \mathrm{~km}$ apart, through the north Howard debris flow along the northeastern side of the lake. The smaller southern outlet was subsidiary and was abandoned soon after its inception, possibly because of minor debris-flow activity from the North Howard debris-flow zone (fig. 15). The northern outlet became the Shingobee River. It began to flow northeastward among small debris flows in the Shingobee tunnel valley and rapidly eroded its way downward through unconsolidated sediments and preexisting tunnel valley stream sediments (fig. 19). Much of the downcutting by the young Shingobee River (fig. 19, cross sections) appears to have been the result of catastrophic drainage from glacial lake Willobee, probably around $14.7 \mathrm{ka}$ after the Bølling warm period was well underway (fig. 17, D-O1, peak A).

The ancestral Shingobee River established its presentday course some time after the emplacement of Ah-GwahChing. As suggested above, rapid downcutting of the debris dam northeast of Shingobee Lake accompanied catastrophic drainage of glacial lake Willobee. A large volume of debrisflow sediment and preexisting fluvial deposits was mobilized and deposited along the southern edge of the Ah-Gwah-Ching block by braided distributaries as the Shingobee River flowed down the lower gradients along the front of the block. Relatively wide floodplains (as much as about $230 \mathrm{~m}$ (750 ft) cross sections; fig. 19) suggest historical deposition over stream banks by the Shingobee River. The modern Shingobee River can be described as an underfit stream. Underfit streams had historically large flow volumes through valleys that are much too large to have been eroded by the small modern stream they contain. Such streams are common features in many Minnesota glacial landscapes. As is the case with the Onigum division, the edge of the Shingobee moraine division was the site of mud and debris flows. Shingobee debris flows along with contemporaneous flows from the Onigum division occupy the Crow Wing valley around Big Bass Lake and Lake Alice, about 1 to $3 \mathrm{~km}(0.6-2 \mathrm{mi})$ northeast of the mapped area. Lake formation in the Crow Wing tunnel system seems likely as a result. Water-well-drillers' logs record several wells in the vicinity of the Crow Wing lakes that may contain lake sediments near the land surface (Minnesota Geological Survey and Minnesota Department of Health, 2010).

The Ah-Gwah-Ching hill-hole pair (fig. 20) and draining of glacial lake Willobee marked the end of $\mathrm{H} 1$ and the beginning of the Bølling warming. By about $14.5 \mathrm{ka}$, the Itasca lobe had retreated 50-60 km (31-37 mi) northward from Shingobee and stabilized for a short time on a small recessional moraine near the city of Bagley (fig. 2A). As Bølling warming continued, ice melted in place, leaving behind an ablation blanket between the recessional moraine and the retreating ice front (Melchior and others, 2005). During the retreat of the Itasca lobe, eskers formed north of the Itasca moraine (Hobbs and Goebel, 1982) and wind lag boulder pavements are common. Permafrost indicators such as ice polygons and contorted bedding developed as the climate became frigid during the Younger Dryas (Melchior and Annexstad, 1996). 


\section{Summary}

The landscape of the Shingobee headwaters area is the result of two glacial advances and two interstadials. The earliest was a middle Wisconsin ice lobe (Hewitt phase) from the eastern Keewatin center that advanced into the area about 27.2 kiloannum. This advance was followed by a short interstade, about 800 years, which in turn was followed about 22.8 kiloannum by a late Wisconsin advance of the Wadena lobe (Itasca phase) from the Keewatin center. Itasca phase ice was in place for about 8.1 kiloannum, retreating about 14.7 kiloannum at the beginning of the Bølling interstade. Modification of topography since the end of the Itasca phase has been relatively minor.

\section{Hewitt Phase (27.2 to <23.6 ka)}

Between H3 and D-O2, Hewitt phase tunnel valleys developed beneath the ice. At least four of these tunnel valleys converged in Walker Bay. Subglacial meltwater was discharged through the Shingobee region by the Shingobee and Crow Wing tunnel valleys. Streams in Hewitt phase tunnel valleys appear to have originated from the area of present day Red Lakes. Periodic, chaotic drainage from subglacial lakes may have accompanied ice surges. Sands and gravels in tunnel valleys show extensive crossbedding at various scales.

Hewitt phase ground moraine (unit hgm) is widely exposed in the Shingobee region. It is characterized by boulder trains, shallow lakes and swamps, low slope angles, and limited relief. The bulk of these deposits are medium-grained sands. Bedding ranges from obscure to massive. Directional landscape elements indicating ice flow direction, such as drumlins and boulder trains, are oriented between north-south and northeast-southwest.

Near the end of the Hewitt phase, ice became stagnant. Reduced hydraulic heads in subglacial tunnels contributed to roof collapse. Ice blocks were buried by outwash on the valley floors. Positions occupied by these ice blocks became modern ice-block lakes such as Shingobee, Howard, Island, and Steel Lakes, and those of the Crow Wing Lake chain. During ice melting, ice-contact stratified deposits and ablation till accumulated on the surface of the stagnant glacier. As the ice disappeared, these deposits were draped over existing subglacial topography. Isolated kames (composed of superposed channel deposits or small local debris accumulations) were also left behind, primarily on tunnel valley floors.

\section{Hewitt-Itasca Interstade (23.6 to $<22.8 \mathrm{ka})$}

The Hewitt-Itasca interstade was coincident with D-O2 and had a relatively short duration (no longer than 800 years).

\section{Itasca Phase (22.8 to $<14.7 \mathrm{ka})$}

Itasca phase ice came from a source within the Keewatin center and entered the Shingobee region as two distinct glacial tongues. The western tongue (Shingobee division of the Itasca moraine) was subject to repeated surges, producing moraine characterized by tectonic features such as en echelon ridges and hill-hole pairs. East of Onigum Point of Leech Lake, an adjacent, contemporary ice tongue, the Onigum division of the Itasca moraine, produced hummocky moraine.

Near the end of Itasca glaciation, overpressured groundwater and high shear stress associated with ice movement enabled transport of a number of large blocks of frozen till, emplacing them along the proximal face of the Itasca moraine. One such block (Ah-Gwah-Ching) was moved southward from Walker Bay and was positioned northeast of the Shingobee headwaters. Debris flows from the Itasca moraine blocked parts of the Shingobee tunnel valley which filled with meltwater to become glacial lake Willobee. Glacial lake Willobee and Ah-Gwah-Ching (16-14.7 kiloannum) were the final products of glacial activity in the Itasca phase at Shingobee.

\section{References Cited}

Aber, J.S., Croot, D.G., and Fenton, M.M., 1989, Glaciotectonic landforms and structures: Dordrecht, Netherlands, Kluwer Academic Publishers, 200 p.

Adams, R.S., Jennings, C.E., Lusardi, B.A., and Ross, M.A., 2011, Evolution of a North American mid-continental paleoice stream system [abs.]: Geological Society of America Abstracts with Program, v. 3, no. 5, p. 216.

Allaby, Michael, 2008, Oxford dictionary of Earth sciences, 3d ed.: Oxford, U.K., Oxford University Press, 654 p.

Alley, R.B., 2004, GISP2 ice core temperature and accumulation data: International Geosphere-Biosphere Program/Past Global Changes (IGBP/pages)/World Data Center for Paleoclimatology, Data Contribution Series 2004-013, NOAA/ NGDC Paleoclimatology Program, Boulder, Colorado, USA: Available at ftp://ftp.ncdc.noaa.gov/pub/data/paleo/ icecore/greenland/summit/gisp2/isotopes/gisp2_temp_ accum_alley2000.txt (last accessed August 2009).

Alley, R.B., Meese, D.A., Shuman, C.A., Gow, A.J., Taylor, K.C., Grootes, P.M., White, J.W.C., Ram, M., Waddington, E.D., Mayewski, P.A., and Zielinski, G.A., 1993, Abrupt accumulation increase in the Younger Dryas termination in the GISP2 ice core: Nature, v. 362, p. 527-529.

American Geosciences Institute, 2013, Glossary of geology: available at www.agiweb.org/pubs/glossaruy.agiweb.org (last accessed January 2013). 
Anderson, J.L., Bell, J.C., Cooper, T.H., and Grigal, D.F., 2001, Soils and landscapes of Minnesota: St. Paul, Minn., University of Minnesota College of Agriculture, Food and Environmental Sciences report FO-02331, revised 2001, $10 \mathrm{p}$.

Anderson, R.C. 1957. Pebble and sand lithology of the major Wisconsin glacial lobes of the Central Lowland: Geological Society of America Bulletin, v. 68, p. 1415-1450.

Ashley, G.M., Shaw, J., and Smith, N.D., 1985, Glacial sedimentary environments: SEPM Short Course Notes 16, Tulsa, Okla., SEPM, 246 p.

Ballantyne, C.K., and Harris, C., 1994. The periglaciation of Great Britain: Cambridge, U.K., Cambridge University Press, 330 p.

Benn, D.I., and Evans, D.J.A., 1998, Glaciers and glaciation: New York, Oxford University Press, 734 p.

Bennike, Ole, 1998, Pingos at Nioghalvfjerdsfjorden, eastern North Greenland: Geology of Greenland Survey Bulletin, v. 180 , p. $159-162$.

Bettis, E.A., III, 1997, Late-middle and early-late Wisconsinan glaciation in north-central Iowa [abs.]: Geological Society of America Abstracts with Programs, v. 29, no. 4, p. 5.

Birks, H.J.B., 1976, Late Wisconsin vegetational history at Wolf Creek, central Minnesota: Ecological Monographs, v. 46, p. $395-429$.

Bluemle, J.P., 1991, The face of North Dakota (revised edition): Bismarck, North Dakota Geological Survey report ED-21, 177 p., 1 plate (scale 1:1,000,000).

Bluemle, J.P., and Clayton, L., 1984, Large-scale glacial thrusting and related processes in North Dakota: Boreas, v. 13 , p. 279-299.

Bond, G.C., Broeker, W., Johnsen, S., McManus, J., Labeyrie, L., Jouzel, J., and Bonani, G., 1993, Correlations between climate records from North Atlantic sediments and Greenland ice: Nature, v. 365, p. 143-147.

Bond, G.C., Heinrich, H., Broecker, W., Labeyrie, L., McManus, J., Andrews, J., Huon, S., Jantschik, R., Clasern, S., Simet, C., Tedesco, K., Klas, M., Bonani, G., and Ivy, S., 1992, Evidence for massive discharges of icebergs into the North Atlantic Ocean during the last glacial period: Nature, v. 360 , p. 245-249.

Bond, G.C., and Lotti, R., 1995, Iceberg discharges into the North Atlantic on millennial time scales during the last glaciation: Science, v. 267, p. 1005-1010.
Bond, G.C., Showers, W., Elliot, M., Evans, M., Lotti, R., Hajdas, I., Bonani, G., and Johnson, S., 1999, The North Atlantic's 1-2 kyr climate rhythm-Relation to Heinrich events, Dansgaard/Oeschger cycles and the Little Ice Age, in Clark, P.U., Webb, R.S., and Keigwin, L.D., eds., Mechanisms of global change at millennial time scales: Washington, D.C., American Geophysical Union Geophysical Monograph 112, p. $35-58$.

Boone, S.J., and Eyles, N., 2001, Geotechnical model for Great Plains hummocky moraine formed by till deformation beneath stagnant ice: Geomorphology, v. 38, p. 109-124.

Boulton, G.S., 1972, Modern Arctic glaciers as depositional models for former ice sheets: Journal of the Geological Society [London], v. 128, p. 361-393.

Boulton, G.S., and Caban, P.E., 1995, Groundwater flow beneath ice sheets, II-Its impact on glacier tectonic structures and moraine formation: Quaternary Science Reviews, v. 14 , p. $563-587$.

Carney, L.M., and Mooers, H.D., 1998, Landform assemblages and glacial history of a portion of the Itasca moraine, north central Minnesota, in Patterson, C.J., and Wright, H.E., Jr., eds., Contributions to the Quaternary studies in Minnesota: Minnesota Geological Survey Reports of Investigations 49 , p. 85-95.

Clark, C.D., 1993, Mega-scale glacial lineations and crosscutting ice flow landforms: Earth Surface Processes and Landforms, v. 18, p. 1-29.

Clark, C.D., 1994, Large-scale ice-moulding, a discussion of genesis and glaciological significance: Sedimentary Geology, v. 91, p. 253-268.

Clarke, G.K.C., 1987, Fast glacier flow, ice streams, surging, and tidewater glaciers: Journal of Geophysical Research, v. 92, p. $8835-8841$.

Clayton, Lee, 1964, Karst topography on stagnant glaciers: Journal of Glaciology, v. 5, p. 107-112.

Clayton, Lee, and Moran, S.R., 1974, A glacial process-form model, in Coates, D.R., ed., Glacial geomorphology: Binghamton, State University of New York, p. 81-119.

Clayton, Lee, Teller, J.T., and Attig, J.W., 1985, Surging of the southwestern part of the Laurentide ice sheet: Boreas, v. 14, p. $235-241$.

Dansgaard, Willi, Clausen, H.B., Gundestrup, N., Hammer, C.U., Johnson, S.J., Kristinsdottir, P.M., and Reeh, N., 1982, A new Greenland deep ice core: Science, v. 218, p. 1273-1277. 
Danzeglocke, Uwe, 2011, Cologne radiocarbon calibration and paleoclimate research package, On Line Cal Pal: Available at www.Calpal-online.de/cgi-bin/quickcal.pl (last accessed December 2012).

Danzeglocke, Uwe, Joris, O., and Weninger, B., 2011, 2007, Calpal 2007 online: Available at http//www.calpal-online.de/ (last accessed August 15, 2011).

Dean, W.E., and Schwalb, A., 2002, The lacustrine carbon cycle as illuminated by the waters and sediments of two hydrologically distinct headwater lakes in north-central Minnesota, U.S.A.: Journal of Sedimentary Research, v. 72, p. $416-431$.

Deschamps, Pierre, Durand, N., Bard, E., Hamelin, B., Camoin, G., Thomas, A.L., Henderson, G.M., Okuno, J., and Yokoyama, Y., 2012. Ice sheet collapse and sea level rise at the Bølling warming 14,600 years ago: Nature, v. 487 , p. $559-564$.

Dreimanis, Aleksis, 1989, Tills, their genetic terminology and classification, in Goldthwaite, R.P., and Matsch, C.L., eds., Genetic classification of glacigenic deposits: Rotterdam, Balkema, p. 17-84.

Erickson, D.R., 1981, A study of littoral groundwater seepage at Williams Lake, Minnesota, using seepage meters and wells: Minneapolis, University of Minnesota M.S. thesis, $135 \mathrm{p}$.

Evans, D.J.A., 1994, The stratigraphy and sedimentary structures associated with complex subglacial thermal regimes at the southwestern margin of the Laurentide ice sheet, southern Alberta, Canada, in Warren, P.J., and Groot, D.G., eds., Formation and deformation of glacial deposits, Meeting of the Commission on Glacial Deposits, Dublin, Ireland, Proceedings: Rotterdam, Balkema, p. 203-220.

Evans, D.J.A., Phillips, E.R., Hiemstra, J.F., and Auton, C.A., 2006, Subglacial till-Formation, sedimentary characteristics and classification: Earth-Science Reviews, v. 78, p. 115-176.

Filby, S.K., Locke, S.M., Person, M.A., Winter, T.C., Rosenberrry, D.O., Nieber, J.L., Gutowski, W.J., and Ito, E., 2002, Mid-Holocene hydrologic model of the Shingobee watershed, Minnesota: Quaternary Research, v. 58, p. 246-254.

Flint, R.F., 1971, Glacial and Quaternary geology: New York, Wiley, $892 \mathrm{p}$.

French, H.M., and Harry, D.G., 1990, Observations of buried glacial ice and massive segregated ice, western arctic coast, Canada: Permafrost and Periglacial Processes, v. 1, p. 31-43.
Gajewski, Konrad, Munoz, S., Peros, M., Viau, A., Morlan, R., and Betts, M., 2011, The Canadian archeological radiocarbon database (CARD): Archeological ${ }^{14} \mathrm{C}$ dates in North America and their paleoenvironmental context: Radiocarbon, v. 53, p. 371-394.

Geotechnicalinfo.com/, 2012, Angle of repose: Available at http://www.geotechnicalinfo.com/geotechnical_glossary. html (last accessed November 2012).

Goldstein, B.S., 1989, Lithology, sedimentology and genesis of the Wadena drumlin field, Minnesota, USA: Sedimentary Geology, v. 62, p. 241-277.

Gravenor, C.P., and Kupsch, W.O., 1959, Ice-disintegration features in western Canada: Journal of Geology, v. 67, p. $48-64$.

Gudmundsson, G.H., 2006, Fortnightly variations in the flow velocity of Rutford ice stream, West Antarctica [abs.]: Nature, v. 444, p. 1063-1064.

Harris, K.L., 1975, Pleistocene geology of the Grand ForksBemidji area, northwestern Minnesota: Grand Forks, University of North Dakota, Ph.D. dissertation, 284 p.

Harris, K.L., 1995, Regional hydrogeological assessmentQuaternary geology, southern Red river Valley, Minnesota: Minnesota Geological Survey Regional Hydrogeologic Assessment Series RHA-3, Part A, 2 plates (scales $1: 200,000$ and $1: 750,000)$.

Harris, K.L., 2006, Surficial geology of the Crookston $30^{\prime} \times$ 60' quadrangle, northwest Minnesota: Minnesota Geological Survey Miscellaneous Map Series Map M-173 (scale $1: 100,000)$.

Harris, K.L., and Knaeble, A.R., 1999, Regional hydrogeologic assessment-Quaternary geology, Otter Tail area, west central Minnesota: Minnesota Geological Survey Regional Hydrogeologic Assessment Series RHA-5, part A, plate 1Surficial geology (scale 1:200,000).

Harris, K.L., Moran, S.R., and Clayton, Lee, 1974, Late Quaternary stratigraphic nomenclature, Red River Valley, North Dakota and Minnesota: North Dakota Geological Survey Miscellaneous Series 52, 47 p.

Heinrich, Hartmut, 1988, Origin and consequences of cyclic ice rafting in the northeast Atlantic Ocean during the last 130,000 years: Quaternary Research, v. 29, p. 142-152.

Hobbs, H.C., and Goebel, J.E., 1982, Geologic map of Minnesota - Quaternary geology: Minnesota Geological Survey State Map Series S-1, scale 1:500,000.

Hooke, R. LeB., and Jennings, C.E., 2006, On the formation of the tunnel valleys of the southern Laurentide ice sheet: Quaternary Science Reviews, v. 25, p. 1364-1372. 
Jørgensen, Fleming, and Sandersen, P.B.E., 2006, Buried and open tunnel valleys in Denmark-Erosion beneath multiple ice sheets: Quaternary Science Reviews, v. 25, p. 1339-1363.

Karls, R.M., 1982, A groundwater model of the Williams Lake watershed, Hubbard County, Minnesota: Tucson, University of Arizona M.S. thesis, 93 p.

Lawson, D.E., 1979, Sedimentological characteristics of the western terminus region of the Matanuska glacier, Alaska: Hanover, New Hampshire, Cold Regions Research and Engineering Laboratory report 79-9, 112 p.

Lawson, D.E., 1981, Sedimentological characteristics and classification of depositional processes and deposits in the glacial environment: Hanover, New Hampshire, Cold Regions Research and Engineering Laboratory report $81-27,16 \mathrm{p}$.

Lusardi, B.A. [compiler], 1996, Quaternary geology of Minnesota [on a postal card]: St. Paul, Minnesota Geological Survey.

Lusardi, B., Anderson, F., and Harris, K.L., 2005, Surficial geology of the Fargo-Moorhead area, Minnesota and North Dakota: Minnesota Geologic Survey draft map, FargoMoorhead area, surficial units and geomorphic features, 1 sheet (scale 1:200,000).

Lusardi, B.A., Johnson, M.D., Adams, R.S., Gowan, A.S., Harris, K.L., Hobbs, H.C., Jennings, C.E., Knable, A.R., and Meyer, G.N., 2011, Quaternary stratigraphy of Minnesota - Characterization and correlation of units [abs.]: Geological Society of America Abstracts with Programs, v. 43 , no. 5 , p. 473.

MacAyeal, D.R., 1993, Binge/purge oscillation of the Laurentide ice sheet as a cause of the North Atlantic's Heinrich events: Palaeoceanography, v. 8, p. 775-784.

Matsch, C.L., 1971, Pleistocene stratigraphy of the New Ulm region, southwestern Minnesota. Madiston, University of Wisconsin PhD. dissertation, $91 \mathrm{p}$.

Meese, D.A., Gow, A.J., Grootes, P., Mayewski, P.A., Zielinski, G., Ram, M., Stuiver, M., Taylor, K.C., and Waddington, E., 1994, The accumulation record from the GISP2 core as an indicator of climate change throughout the Holocene: Science, v. 266, p. 948-952.

Melchior, R.C., and Annexstad, J.O., 1996, Glaciers and glacier geology of the Leech Lake watershed: Bemidji, Minn., Bemidji State University, 70 p.

Melchior, R.C., Gleason, L., and Macgregor, M., 2005, Stream piracy and the TMDL at Walker Brook [abs.]: Geological Society of America Abstracts with Programs, v. 37, no. 5, p. 23.
Meyer, G.N., and Knaeble, A.R., 1995, Surficial geology, C-10 Atlas, part A, plate 3, of Meyer, G.N., C-10 Geologic atlas of Stearns County, Minnesota: Minnesota Geological Survey County Atlas C-10, pt. A (scale 1:100,000): Available at $h t t p: / / p u r l . u m n . e d u / 58515$ (last accessed July 2010).

Minnesota Department of Administration, 1987, Geologic map of Minnesota-Quaternary geology (from Minnesota Geological Survey map S-1, 1982); digital version, Quatgeo: Available at http://www.mngeo.state.mn.us/chouse/metadata/quatgeo.html (last accessed October 2010).

Minnesota Department of Natural Resources (Management Information Services, Minnesota Data Deli), 2010. Minnesota Data Deli shapefiles (last accessed October 2010). CTYBDLN2. Available at http://deli.dnr.state.mn.us/ metadata.html?id=L220000020202

CNTYRDLN3. Available at http://deli.dnr.state.mn.us/metadata.html?id=L300000010202

DLGSTLN2. Available at http://deli.dnr.state.mn.us/ metadata.html?id=L260000052102

LAKESPY2. Available at http://deli.dnr.state.mn.us/metadata.html?id=L260000062101

MAJRDLN. Available at http://deli.dnr.state.mn.us/ metadata.html? id $=$ L300000140202

PLXXPT3. Available at http://deli.dnr.state.mn.us/metadata.html?id=L220000280203

RIVERLN2. Available at http://deli.dnr.state.mn.us/metadata.html?id=L260000180202

SHDr_bwim3. Available at http://deli.dnr.state.mn.us/metadata.html?id=L390002820606

STATEPY2. Available at http://deli.dnr.state.mn.us/metadata.html?id=L220000160201

TWPDLN3. Available at http://deli.dnr.state.mn.us/metadata.html? id $=$ L300000110202

Minnesota Department of Transportation, Aggregate Resources, County Maps, 2003. Available at http://www.dot. state.mn.us/materials/aggcpitmaps.html.

Minnesota Geological Survey and Minnesota Department of Health, 2010, County well index online: Available at http://www.health.state.mn.us/divs/eh/cwi/index.html (last accessed November 2011).

Mooers, H.D., 1990, A glacial-process model-The role of spatial and temporal variations in glacial thermal regime: Geological Society of America Bulletin, v. 102, p. 243-251.

Mooers, H.D., and Lehr, J.D., 1997, Terrestrial record of Laurentide ice sheet reorganization during Heinrich events: Geology, v. 26, p. 987-990. 
Mooers, H.D., and Norton, A.R., 1997, Glacial landscape evolution of the Itasca/St. Croix moraine interlobate area including the Shingobee River headwaters area, in Winter, T.C., ed., Hydrological and biogeochemical research in the Shingobee River headwaters area: U.S. Geological Survey Water-Resources Investigations Report 96-4215, p. 3-11.

Moran, S.R., Clayton, L., Hooke, L., Fenton, M.M., and Andriashek, L.D., 1980, Glacier bed landforms of the Prairie region of North America: Journal of Glaciology, v. 25, p. 457-476.

Nobles, N.H., and Weertman, J., 1971, Influence of irregularities of the bed of an ice sheet on deposition rate of till, in Goldthwaite, R.P., ed., Till-A symposium: Columbus, Ohio State University Press, p. 117-126.

Norton, A.R., 1983, Quaternary geology of the St. Croix and Itasca moraine interlobate area: Duluth, University of Minnesota, M.S. thesis, 119 p.

Nye, J.F., 1973, Water at the bed of a glacier-Symposium on the hydrology of glaciers: Cambridge, U.K., Association Internationale d'Hydrologie Scientifique Publication 95, p. 189-194.

Ojakangas, R.W., and Matsch, C.L., 1982, Minnesota's geology: Minneapolis, University of Minnesota Press, 255 p.

Patterson, C.J., and Hooke, R. LeB., 1995, Physical environment of drumlin formation: Journal of Glaciology, v. 41, p. 30-38.

Perkins, R.L., 1977, The late Cenozoic geology of west-central Minnesota from Moorhead to Park Rapids: Grand Forks, University of North Dakota, M.A. thesis, 99 p.

Rahmstorf, Stephan, 2002, Ocean circulation and climate during the past 120,000 years: Nature, v. 419, p. 208-216.

Rahmstorf, Stephan, Crucifix, M., Ganopolski, A., Goosse, H., Kamenkovich, I., Knutti, R, Lohmann, G., Marsh, R., Mysak, L.A., Wang, Z., and Weaver, A.J., 2005, Thermohaline circulation hysteresis-A model intercomparison: Geophysical Research Letters, v. 32, no. 23, L23605. Available at $h t t p: / / a d s a b s . h a r v a r d . e d u / a b s / 2005 G e o R L . .3223605 R$ ) (last accessed December 2011).

Rampton, V.N., 1988, Quaternary geology of the Tuktoyaktuk coastlands, N.W.T.: Geological Survey of Canada Memoir 423, $98 \mathrm{p}$.

Reimer, P.J., Baille, M.G.L., Bard, E., Bayliss, A., Beck, J.W., Bertrand, C., Blackwell, P.G., and 22 others, 2004, INTCAL04 terrestrial radiocarbon age calibration, 0-26 Cal kyr: Radiocarbon, v. 46, p. 1029-1058.

Rose, James, 1987, Drumlins as part of a glacial bedform continuum, in Menzies, John, and Rose, J., eds., Drumlin Symposium: Rotterdam, Balkema, p. 103-116.
Sadura, S.J., Martini, I.P., Endres, A.L., and Wolf, K., 2006, Morphology and GPR stratigraphy of a frontal part of an end moraine of the Laurentide ice sheet-Paris moraine near Guelph, Ontario, Canada: Geomorphology, v. 75, p. 212-225.

Schwalb, Antje, and Dean, W.E., 2002, Reconstruction of hydrological changes and response to effective moisture variations from north-central USA lake sediments: Quaternary Science Reviews, v. 21, p. 1541-1554.

Seaberg, J.K., 1985, Geohydrologic interpretation of glacial geology near Williams Lake, north-central Minnesota, with emphasis on lake-groundwater interaction: Minneapolis, University of Minnesota, M.S. thesis, 141 p.

Sharp, Martin, 1985, Sedimentation and stratigraphy at Eyjbakkjökull—An Icelandic surging glacier: Quaternary Research, v. 24, p. 268-284.

Shaw, John, 1985, Subglacial and ice marginal environments, in Ashley, G.M., Shaw, J., and Smith, N.D., eds., SEPM Short Course 16-Glacial sedimentary environments: Tulsa, Okla., SEPM, p. 7-84.

Shaw, John, 2002, The meltwater hypothesis for subglacial bedforms: Quaternary International, v. 90, p. 5-22.

Shaw, J., and Sharpe, D.R., 1987, Drumlin formation by subglacial meltwater erosion: Canadian Journal of Earth Science, v. 24, p. 2316-2322.

Siegel, D.I., and Winter, T.C., 1980, Hydrologic setting of Williams Lake, Hubbard County, Minnesota: U.S. Geological Survey Open-File Report 80-403, 56 p.

Sugden, D.E., Marchant, D.R., Potter, N., Jr., Souchez, R.A., Denton, G.H., Swisher, C.C., III, and Tison, J.L., 1995, Preservation of Miocene glacier ice in East Antarctica: Nature, v. 376, p. 412-414.

Taylor, K.C., Lamorey, G.W., Doyle, G.A., Alley, R.B., Grootes, P.M., Mayewski, P.A., White, J.W.C., and Barlow, L.K., 1993, The "flickering switch" of late Pleistocene climate change: Nature, v. 361, p. 432-436.

Thorleifson, L.H., Harris, K.L., Hobbs, H.C., Jennings, C.E., Knaeble, A.R., Lively, R.S., Lusardi, B.A., and Meyer, G.N., 2007, Till geochemical and indicator mineral reconnaissance of Minnnesota. Minnesota Geological Survey Open File Report OFR-07-01, 55 p.

U.S. Department of Agriculture, Natural Resources Conservation Service, 2007, National soil survey handbook, title 430VI: Available at http://soils.usda.gov/technical/handbook/ (last accessed October 2010). 
U.S. Geological Survey Geologic Names Committee, 2010, Divisions of geologic time-Major chronostratigraphic and geochronologic units: U.S. Geologic Survey Fact Sheet 2010-3059, 2 p.

Welch, P.S., 1948. Limnological methods: New York, McGraw Hill, $381 \mathrm{p}$.

Winsborrow, M.C.M., Clark, C., and Stokes, D., 2006, What controls the location of Laurentide palaeo-ice streams? [abs.], Program and Abstracts, 36th Annual International Arctic Workshop, March 16-18, 2006, INSTAAR—Institute of Arctic and Alpine Research, University of Colorado at Boulder, v. 19, p. 81.

Winter, T.C., 1997, Hydrological and biogeochemical research in the Shingobee River headwaters area: U.S. Geological Survey Water-Resources Investigations Report 96-4215, $210 \mathrm{p}$.

Winter, T.C., and Rosenberry, D.O., 1997, Physiographic and geologic characteristics of the Shingobee River headwaters area, in Winter, T.C., ed., 1997, Hydrological and biogeochemical research in the Shingobee River headwaters area, north central Minnesota: U.S. Geological Survey WaterResources Investigations Report 96-4215, p. 11-19.

Winters, W.A., 1961, Landforms associated with stagnant ice: Professional Geographer, v. 13, p. 19-23.

Wright, H.E., 1962. Role of the Wadena lobe in the Wisconsin glaciation of Minnesota: Geological Society of America Bulletin, v. 73, p. 73-100.

Wright, H.E., 1972, Quaternary history of Minnesota, in Sims, P.K., and Morey, G.B., eds., Geology of Minnesota-A centennial volume: Minnesota Geological Survey, p. 561-580.

Wright, H.E., 1973, Tunnel valleys, glacial surges, and subglacial hydrology of the Superior lobe, Minnesota, in Black, R.F., Goldthwaite, R.P., and Williams, H.B., eds., The Wisconsinan stage: Geological Society of America Memoir 36, p. 251-306.

Wright, H.E., 1993, History of the landscape in the Itasca region, in Bradbury, J.P., and Dean, W.E., eds., Elk Lake, Minnesota-Evidence for rapid climate change in the north-central United States: Geological Society of America Special Paper 276, p. 7-19.

Wright, H.E., Stefanova, I., Tian, Jian, Brown, T.A., and Hu, Feng Sheng, 2004, A chronological framework for the Holocene vegetational history of central Minnesota-The Steel Lake pollen record: Quaternary Science Reviews, v. 23, p. 611-626.

Zilkoski, D.B., Richards, J.H., and Young, G.M., 1992. Results of the general adjustment of the North American datum of 1988: American Congress on Surveying and Mapping, Surveying and Land information Systems, v. 52, p. 133-149. 


\section{Glossary}

Most definitions are derived from the Glossary of Geology (American Geosciences Institute, 2013 online edition) and the Oxford Dictionary of Earth Sciences (Allaby, 2008). A definition without attribution is from one of these sources. Other sources are indicated as appropriate.

\section{A}

ablation The loss of solid mass from a glacier or the process causing that loss. Ice melting, sublimation, and calving, for instance, all cause ablation.

accumulation The addition of solid mass to a glacier or the process causing that addition. Snow, freezing rain, and frost, for instance, all cause ice to accumulate.

angle of repose The maximum angle, just before failure, of a slope composed of unconsolidated granular material (Geotechnicalinfo.com, 2012 (last accessed January 10, 2013)). The slope angle commonly ranges between 33 and $37^{\circ}$.

\section{B}

Bølling A time interval near the end of the Itasca phase about 14 ka calendar years. Recognized by pollen and stratigraphy. Named for the type section in Denmark. In the Shingobee region, the Bølling is more or less correlative with the ItascaDes Moines interstade.

Boralf A suborder of the soil order Alfisol. Alfisols commonly occur under forests in humid middle latitudes. Boralfs are well drained, dull brown or yellowish brown, and found in cool or cold regions (U.S. Department of Agriculture Natural Resources Conservation Service, 2007).

boulder train A linear strew of glacial boulders, exposed at the surface and aligned parallel to the direction of glacier movement or to the axis of a subglacial drainage system.

boulder pavement A surface largely covered by cobbles and boulders derived from an underlying till. Fine-grained material (such as silt or sand) has been removed by erosion (wind, water, or ice). Also called a wind lag.

borrow pit A ditch or other excavation near a road or other construction that serves as a source of fill.

braided stream A shallow anastomosing stream with an exceptionally high bed load that forms numerous, in-stream sand bars. The bars block the main channels causing those channels to repeatedly divide and rejoin forming a braided pattern. Streams flowing from glaciers are commonly braided.

\section{C}

competence The ability of a stream to transport debris. Competence is measured by the diameter of the largest particle transported.

composite ridge A distinctive glaciotectonic landform composed of multiple slices of up-thrust and contorted blocks of ice and basal sediments. A composite ridge is often interlayered with debris-flow and fluvial materials (Benn and Evans, 1998, p. 463). These features are sometimes called "thrust moraines."

crossbedding Alignment of minor bedding at an angle to the main stratification. Crossbedding is caused by an avalanche of grains down the lee slopes of features such as ripple marks, dunes, and sand waves. Crossbedding types can be used to estimate flow regime in fluvial deposits.

cryoturbation A collective term for distortion, solifluction, churning and other soil disturbances caused by pressure initiated by frost action in frozen ground.

D

Dansgaard-0eschger event A period of rapid warming, commonly in a matter of decades, followed by gradual cooling during a longer period (Bond and others, 1999).

debris flow A downslope movement of a mass of rock, mud, and water, more than half the particles of which are sand size or larger. Large clasts are supported by a muddy matrix. These features may move rapidly or slowly depending on degree of water saturation.

decollement (French — detachment, "unsticking") The sliding and subsequent deformation of strata over strata beneath; a boundary separating deformed strata from underlying strata which are not similarly deformed.

drumlin An elongated, streamlined hill whose long axis parallels ice flow. It originates from subglacial molding and deformation of substrate by ice flow. 
E

en echelon (French - in step-like arrangement) An approximately parallel alignment of similar linear features (for example, faults, folds, ridges) at an oblique angle to a particular direction. In this report, refers to the arrangement of composite ridges in the Shingobee division of the Itasca moraine. The strike of these features when associated with a glacier is commonly at right angles to local ice flow.

\section{$\mathbf{F}$}

fluvial (Latin-fluvius; river, running water) A feature associated with streams.

G

GISP2 A commonly used acronym for the second Greenland Ice Sheet Project, which recovers, curates, and analyzes ice cores drilled into the Greenland Ice Sheet (Alley, 2004).

glacial karst Widespread formation of water-filled hollows and channels by superficial melting on glaciers that are mantled by large amounts of supraglacial debris. Also called “ice-stagnation topography” (Benn and Evans, 1998).

glaciotectonic Structural deformation of sediment or bedrock as a direct result of glacial movement or loading (Aber and others, 1989). Also called cryotectonic.

grading In reference to graded bedding, a systematic change in average grain size within a bed. In normal grading, grain size decreases upward; in reverse grading, grain size increases upward.

\section{ground moraine See moraine.}

\section{H}

Heinrich event An event recognized by layers of ice-rafted debris in the North Atlantic. The layers represent surges of the Laurentide ice margin that introduced fresh water and icerafted debris into the oceanic system. Heinrich events occurred at the end of major glacial intervals and immediately preceded the warming of Dansgaard-Oeschger events.

Hewitt phase A regional, informal subdivision of the latter part of the middle Wisconsin of the Laurentide glacier in westcentral Minnesota. The Hewitt phase was active between 27.2 and $23.6 \mathrm{ka}$ (Wright, 1972). hill-hole pair A basin (hole) excavated by glaciotectonic processes accompanied by repositioned eroded material (hill) down-glacier. At Shingobee, the resulting landscape consists of a lake with a volume approximating that of an adjacent downstream kame (Bluemle and Clayton, 1984).

Histosol An organic soil containing more than 20 percent organic material to a depth of 40 centimeters. Also called "peat" or "muck" (U.S. Department of Agriculture Natural Resources Conservation Service, 2007).

hummocky moraine "Knob and kettle" topography—randomly dispersed small hills and swales formed during melting at the margins of active or stagnating glaciers.

I

ice polygon A relatively large polygonal feature that forms networks in permafrost by thermal expansion and contraction of ground ice. Also called ice-wedge polygons.

interstadial A warmer, usually ice-free, interval between two glaciations.

inverted topography A topographic feature that has changed its relationship with its surroundings, as when a hill becomes a valley or a valley fill becomes a ridge because of differential erosion. Also called inverted relief.

Itasca phase A regional, informal subdivision of the middle part of the late Wisconsin stage of the Laurentide Itasca lobe in north-central Minnesota. The Itasca phase existed between 22.8 and $14.7 \mathrm{ka}$ (Wright, 1972).

$\mathbf{J}$

jökulhlaup (Icelandic—lake burst) A sudden, massive increase in discharge into proglacial streams which then gradually tapers off as a subglacial or supraglacial lake drains away.

K

kame A hill composed of glacially derived stratified sediment whose slopes are near the angle of repose. Commonly formed in ice-walled basins in the terminal zones of stagnant or slowly moving ice.

katabatic The downhill drainage of high-density (cold) air from a greater elevation, such as a glacier surface, to a lower elevation, such as a periglacial region. 
Keewatin A region in Canada north and west of Winnipeg, Manitoba, that served as the accumulation zone for the Des Moines phase glacier. The Des Moines ice entered Minnesota from the northwest. Debris from this source region is identified by its large content of granite and carbonate rocks. The term also refers to a Precambrian province in the Lake Superior region (Wright, 1972).

\section{$\mathbf{L}$}

Labradorean Glacial ice or debris that originated in a region in Canada south and east of Hudson Bay. This region was the accumulation zone for the Itasca and Hewitt phase glaciations that entered Minnesota from the north and northeast. Debris from this source region is identified by its large content of basalt and moderate to low content of carbonate rock (Wright, 1972).

lacustrine (Latin-lacus, lake) A feature associated with lakes or deposits in lakes.

Laurentide An ice sheet that covered hundreds of thousands of square miles in North America, including most of Canada and a large portion of the northern United States. At its maximum extent, its margin reached as far south as Illinois, Kansas, and Nebraska. The ice sheet was variously active between about 1,600,000 and about 10,000 years ago; it advanced and retreated several times during the Pleistocene (Ojakangas and Matsch, 1982).

lodgement till A till deposited by ice at the base of an active glacier. These tills are usually compact and fissile. They commonly exhibit a fabric oriented in the direction of ice flow.

loess A deposit of windblown dust, mostly silt size.

\section{M}

marl Freshwater deposits of calcium carbonate. Marl is common in northern lakes. Also called bog lime.

massive In reference to rock units, stratum that is internally homogeneous, without crossbedding or other internal structure between its upper and lower contacts.

matrix supported In some poorly sorted deposits, larger rocks (pebble to cobble size) that are not in contact with one another; they are suspended in a matrix of finer-grained material. Common in some mud and debris flows. Also called mud support. megaflute A long, narrow bedform that developed beneath moving glaciers. A megaflute has a long axis that parallels ice flow. These structures have low relief and a high length-towidth ratio. Some megaflutes are as much as 72 kilometers (45 miles) long (Clark, 1993).

meltout till Glacial debris deposited during the melting of stagnant or very slowly moving ice (Benn and Evans, 1998).

mode The value or class of values most commonly present in a statistical distribution. In a range of grain sizes, the mode is the most abundant particle size.

moraine A general term referring to glacial material deposited directly by glacial ice. Types of moraine are denoted by their positions. Terminal (end) moraine lies at the terminus of a glacier, ground moraine beneath the glacier, and interlobate moraine between two independent glacial tongues.

$\mathbf{N}$

$\mathbf{0}$

0chrept A suborder in the soil order Inceptisol. An Inceptisol is a young soil showing only the early stages of horizon development. An Ochrept is pale and has little or no stratification and thin or absent organic carbon layers. It tends to form a hardpan when dry (U.S. Department of Agriculture Natural Resources Conservation Service, 2007).

Ojibwe The language used by the Anishinabe (Chippewa tribe) in northern Minnesota. Sometimes used as the tribal name as well. Many place names in Minnesota have Ojibwe origins.

outwash An extensive apron of stratified sands and gravels deposited by meltwater streams along the margins of a glacier.

$\mathbf{P}$

permafrost Permanently frozen ground. Permafrost is presently found in Arctic regions and at high elevations. The nearsurface portions of permafrost may thaw during the summer months and form a water-saturated, easily deformable mud slurry called the active layer.

pingo A mound of soil covering an ice core, which is fed from beneath by groundwater. Pingos are found exclusively in permafrost regions. Large pingos may be 70 meters ( 230 feet) high and as much as 2 kilometers (1.2 miles) in diameter. Pingos are sometimes called frost mounds. 
postglacial A time interval after glaciation has ceased. Also called an altithermal.

proglacial A position immediately in front of a glacial terminus.

provenance A place of origin. Used to describe the source region of glacial ice or glacial debris.

Psamment A deposit of unconsolidated sand. Psamment is a suborder of the Entisols (soils with no identifiable profile development). A Psamment is essentially unaltered substrate (U.S. Department of Agriculture Natural Resources Conservation Service, 2007).

\section{0}

Quaternary The second (younger) period of the Cenozoic Era. The Tertiary Period is the older; it began about 65.5 million years ago. The Quaternary Period, which began about 2.59 million years ago, is divided into two parts, the Pleistocene and the Holocene Epochs. The Pleistocene Series is represented by physical entities such as till or rock. The duration (a time-dependent term) of the Pleistocene, however, requires the term epoch. The Pleistocene Epoch lasted between 2.59 million years ago and about 11,700 years ago. The Holocene Epoch runs from about 11,700 years ago to present (U.S. Geological Survey Geologic Names Committee, 2010).

\section{$\mathbf{R}$}

S

skew A mode of a statistical distribution that has a value different from (either greater or less) the median. With regard to grain size in sediments, skew is used to refer to excess coarser or finer particles.

slump Describes a rotational type of slope failure in relatively dry material. Debris at the base of the failure plane rotates upward away from the initial slope. Debris at the top of the failure plane rotates downward resulting in an overall rotation around an axis parallel to the original slope. Term may also be used to describe failure by undercut slopes. Slumps may be rapid or slow events.

solifluction A viscous downslope movement of waterlogged soil, usually slow (less than 1 meter per year) but sometimes quite rapid (tens of meters per year). Solifluction is especially common in the active layer of permafrost soils. sorting The process by which sedimentary particles with a common characteristic (such as size, shape, or specific gravity) are naturally selected and separated from associated but dissimilar particles during transport. In a well-sorted sediment, most constituent particles are about the same size. In a poorly sorted sediment, a wide variety of grain sizes are present.

stadial A period of glacial advance during a cold part of a stage of glaciation that includes both warm and cold substages. A substage of a glacial stage marked by a glacial readvance. Stadials discussed in this report are the Hewitt, Itasca, and Des Moines stadials of the Wisconsin glaciation. (Des Moines stadial not mentioned in text but is shown on table 1 and some figures.)

stream terrace Planar surfaces along the walls of stream valleys that were originally parts of floodplains. The former floodplains are abandoned when the stream erodes downward so that the present day stream channel lies below terrace level.

streamline hill As used here, any elongated topographic high that forms beneath an active ice sheet and whose long axis parallels ice flow (for example, drumlins) (Rose, 1987).

sublimation A change in physical state from a solid (for example, ice) directly to a gas (for example, water vapor) without passing through a liquid stage.

subglacial Position beneath the ice of a glacier.

subpolar A category of a temperature-based classification of glaciers. In a polar glacier, ice temperature is predominantly below the pressure-melting point. In a subpolar glacier, ice temperature is at the pressure-melting point at its base but may be below that temperature on much of its surface and along its margins. In a temperate glacier, ice temperature can be at the pressure melting point throughout. Subpolar glaciers are also called polythermal glaciers.

supraglacial Position on the top surface of the ice.

surge When applied to glaciers, a period of very rapid flow. Usually a sudden increase in the velocity of a

glacier. Surges are commonly periodic and can increase the flow rate by an order of magnitude or more (Wright, 1973).

swale A hollow or shallow low place in the topography, sometimes containing marshy vegetation. 
$\mathbf{T}$

till Typically, a poorly sorted material directly deposited by glacial ice. Till may be modified somewhat after depositon by water, wind, or other agents. Also called drift.

tunnel valley A linear trench, initially cut by subglacial streams, in till deposits beneath an active glacier. Tunnel valleys may have been straightened, deepened, and widened by flowing glacial ice such that their axes are more or less parallel to ice flow.

turbidite A deposit formed by a bottom current carrying a large sediment load. Such currents may be derived from submarine slope failure, such as collapse of a delta front or shoreline, or from rivers with a very high suspended load. Among other features, turbidite usually has normally graded bedding and is moderately sorted.

\section{U}

V

valley train A linear body of outwash, typically confined within valley walls, that marks the distal position of a proglacial stream. A valley train may extend many kilometers beyond the glacier front.

varve An annual sedimentary couplet consisting of a lower, light-colored silty or sandy layer formed during the summer and an overlying clayey, organic-rich, layer formed during the winter.

\section{W}

$\mathbf{X}$

y

younger dryas The cold period between the Bølling warm interval and the beginning of the Holocene. Des Moines glaciation occurred during this time.

\section{Z}

Publishing support provided by:

Denver Publishing Service Center

For more information concerning this publication, contact: Chief, Branch of Regional Research, Central Region

U.S. Geological Survey

Box 25046, Mail Stop 418

Denver, CO 80225

(303) 236-5021

Or visit the USGS National Research Program Web site at: http://water.usgs.gov/nrp/ 


\section{$\frac{\mathbb{3}}{3}$}

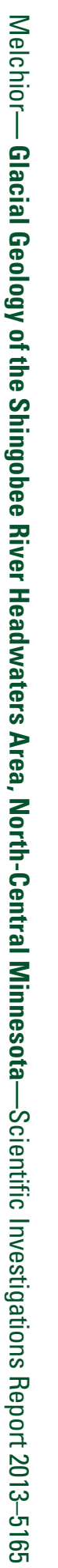

